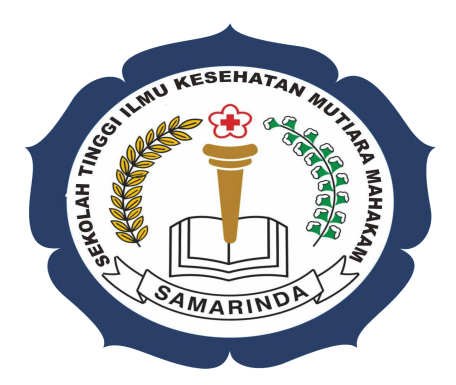

Modul Ajar

\title{
MANAJEMEN SUMBER DAYA MANUSIA
}

\author{
Penyusun: \\ Erwin Purwaningsih
}


Program Studi Administrasi Rumah Sakit

STIKES Mutiara Mahakam

Samarinda

2020 


\section{KATA PENGANTAR}

Puji dan syukur penulis haturkan kepada Allah SWT atas rahmat dan ridho nya, sehingga penyusunan media pembelajaran ini dapat selesai tepat waktu. Modul ini disusun dengan tujuan untuk membantu para mahasiswa untuk memahami dan memperoleh gambaran mengenai konsep-konsep dalam materi mata kuliah manajemen sumber daya manusia (MSDM). Pengaturan dan tata kelola aspek sumber daya manusia menjadi salah satu aspek penting terhadap pencapaian tujuan suatu organisasi. Oleh karena menjadi hal penting untuk mahasiswa untuk menguasai segala aspek SDM yang ada di dunia kerja nantinya. Faktor perencanaan, pengorganisasian, aktualisasi dan kontrol menjadi hal kunci yang harus dikuasai dari materi perkuliahan ini

Demikian kiranya deskripsi kami selaku tim penyusun, kiranya modul ini dapat memberi manfaat bagi para pembacanya, khususnya mahasiswa peserta perkuliahan manajemen sumber daya manusia.

Samarinda, 3 Januari 2020

Penyusun 


\section{DAFTAR ISI}

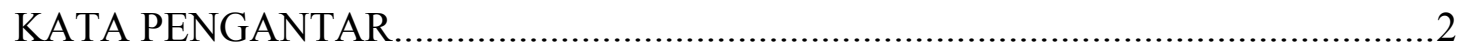

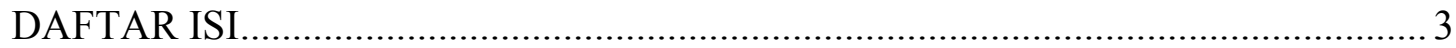

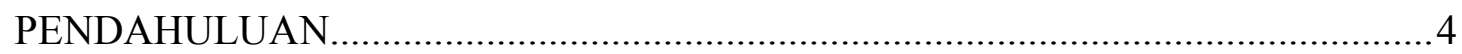

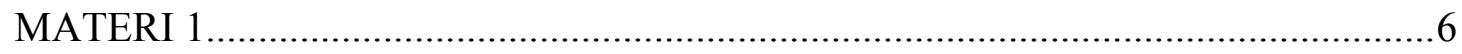

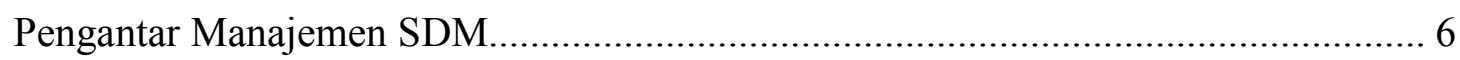

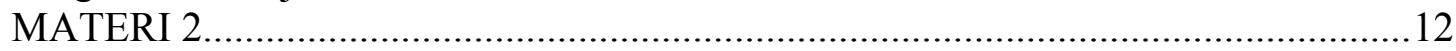

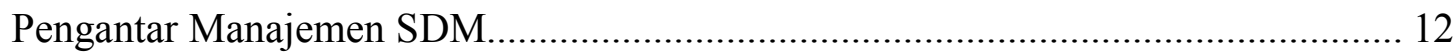

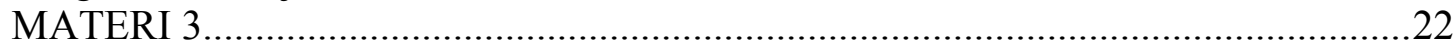

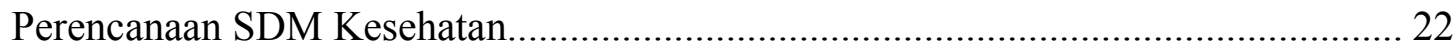

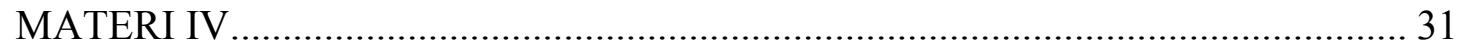

Job Analysis dan Elemen Desain Pekerjaan............................................................. 31

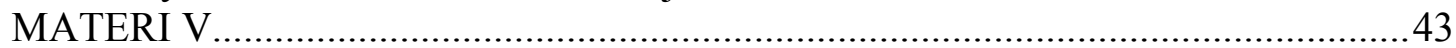

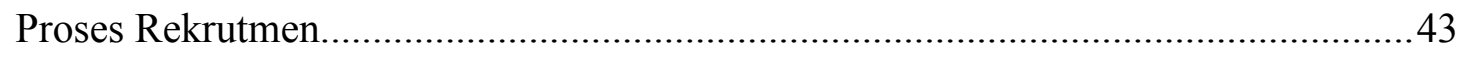

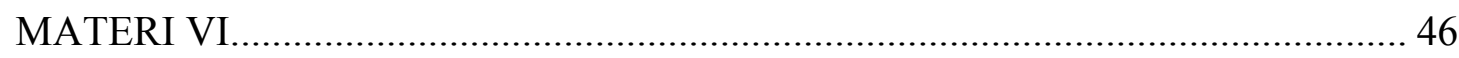

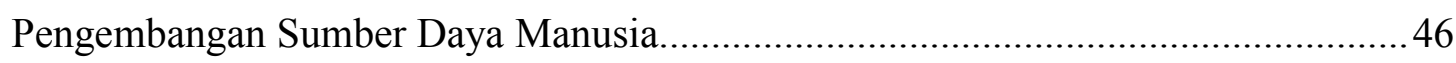

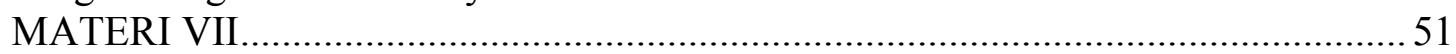

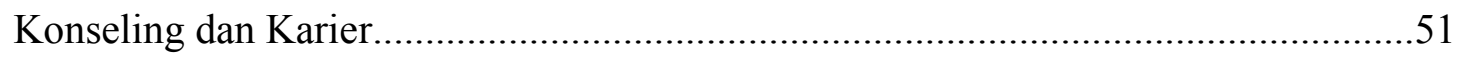

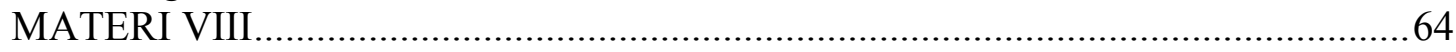

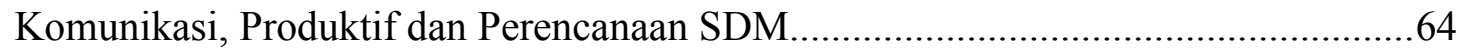

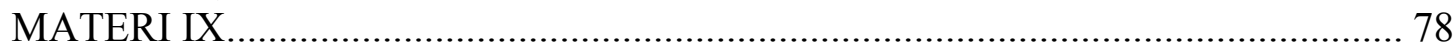

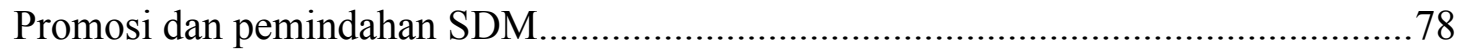

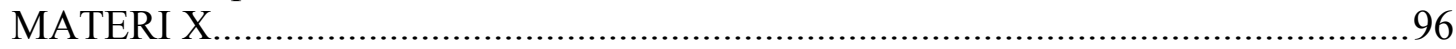

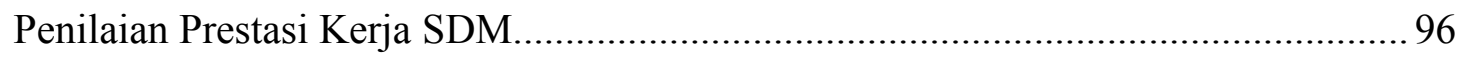

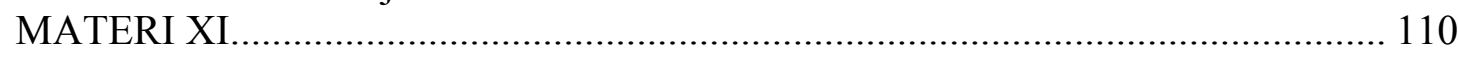

Kompensasi, Keamanan dan Kesehatan SDM.................................................... 110

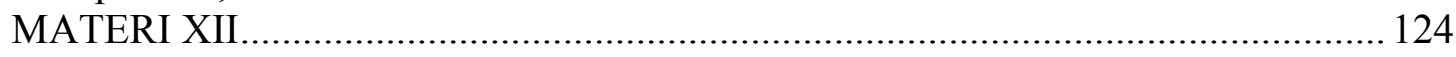

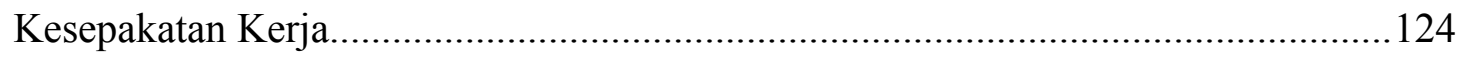

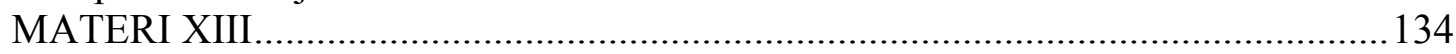

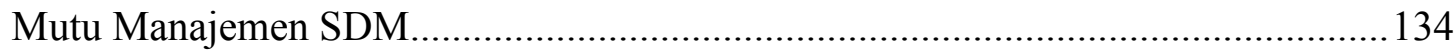

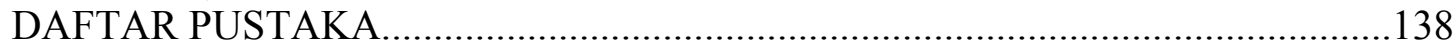




\section{PENDAHULUAN}

\section{Pengantar}

Mata kuliah ini bertujuan untuk membantu mahasiswa dan atau pembaca memahami konsep, teori dan aplikasi praktis manajemen sumber daya manusia. Fungsi manaemen sumber daya manusia ini penting dalam menentukan kualitas sumber daya manusia dalam suatu perusahaan/organisasi.

\section{Jadwal Perkuliahan}

\begin{tabular}{|c|c|c|c|c|}
\hline Pertemuan & Materi & Durasi & Metode & Sumber \\
\hline 1 & $\begin{array}{l}\text { Pendahuluan (Kontrak } \\
\text { Perkuliahan, Aturan - } \\
\text { Aturan dalam Perkuliahan) }\end{array}$ & 100 menit & $\begin{array}{l}\text { Model Blended Learning dengan } \\
\text { metode ceramah dan diskusi } \\
\text { online }\end{array}$ & - \\
\hline 2 & $\begin{array}{l}\text { Manajemen Sumber Daya } \\
\text { Manusia (MSDM) }\end{array}$ & 100 menit & $\begin{array}{l}\text { Model Blended Learning dengan } \\
\text { metode ceramah dan diskusi } \\
\text { online }\end{array}$ & Nitisemito dkk, 2000 \\
\hline 3 & $\begin{array}{l}\text { Strategi MSDM, Peluang } \\
\text { dan Ancaman }\end{array}$ & 100 menit & $\begin{array}{l}\text { Model Blended Learning dengan } \\
\text { metode ceramah dan penugasan } \\
\text { terhadap mahasiswa }\end{array}$ & Moorhed dkk, 2013 \\
\hline 4 & Perencanaan SDM & 100 menit & $\begin{array}{l}\text { Discovery Learning \&Small } \\
\text { Group Discusion }\end{array}$ & James dkk, 2008 \\
\hline 5 & $\begin{array}{l}\text { Job Analysis dan Elemen } \\
\text { Desain Pekerjaan }\end{array}$ & 100 menit & $\begin{array}{l}\text { Model Blended Learning dengan } \\
\text { metode ceramah dan penugasan } \\
\text { terhadap mahasiswa }\end{array}$ & Donni, 2014 \\
\hline 6 & Proses Rekrutmen & 100 menit & $\begin{array}{l}\text { Discovery Learning \&Small } \\
\text { Group Discusion }\end{array}$ & Jono dkk, 2014 \\
\hline 7 & Pengembangan SDM & 100 menit & $\begin{array}{l}\text { Discovery Learning \&Small } \\
\text { Group Discusion }\end{array}$ & Didit, 2013 \\
\hline \multicolumn{5}{|c|}{ UTS } \\
\hline 9 & Konseling dan Karier & 100 menit & $\begin{array}{l}\text { Discovery Learning \&Small } \\
\text { Group Discusion }\end{array}$ & Djuremi, 2016 \\
\hline 10 & $\begin{array}{l}\text { Komunikasi, Produktif dan } \\
\text { Perencanaan SDM }\end{array}$ & 100 menit & $\begin{array}{l}\text { Model Blended Learning dengan } \\
\text { metode ceramah dan diskusi } \\
\text { online serta penugasan terhadap } \\
\text { mahasiswa }\end{array}$ & Stephen, 2006 \\
\hline 11 & $\begin{array}{l}\text { Promosi dan Pemindahan } \\
\text { SDM }\end{array}$ & 100 menit & $\begin{array}{l}\text { Model Blended Learning dengan } \\
\text { metode ceramah dan diskusi }\end{array}$ & Joko, 2008 \\
\hline
\end{tabular}




\begin{tabular}{|c|l|l|l|l|}
\hline & & & $\begin{array}{l}\text { online serta penugasan terhadap } \\
\text { mahasiswa }\end{array}$ & \\
\hline 12 & $\begin{array}{l}\text { Penilaian Prestasi Kerja } \\
\text { SDM }\end{array}$ & 100 menit & $\begin{array}{l}\text { Model Blended Learning dengan } \\
\text { metode ceramah dan diskusi }\end{array}$ & Nanda dkk, 2013 \\
\hline 13 & $\begin{array}{l}\text { Kompensasi, Keamanan } \\
\text { dan Kesehatan SDM }\end{array}$ & 100 menit & $\begin{array}{l}\text { Model Blended Learning dengan } \\
\text { metode ceramah dan diskusi } \\
\text { online serta penugasan terhadap } \\
\text { mahasiswa }\end{array}$ & Gary, 2009 \\
\hline 14 & Kesepakatan Kerja & 100 menit & $\begin{array}{l}\text { Model Blended Learning dengan } \\
\text { metode ceramah dan diskusi } \\
\text { online serta penugasan terhadap } \\
\text { mahasiswa }\end{array}$ & Donal, 2007 \\
\hline 15 & Studi Kasus & 100 menit & $\begin{array}{l}\text { Discovery Learning \&Small } \\
\text { Group Discusion }\end{array}$ & - \\
\hline
\end{tabular}




\section{MATERI 1}

\section{Pengantar Manajemen SDM}

\section{A. Sub Materi 1: Deskripsi Mata Kuliah}

Manajemen SDM merupakan mata kuliah yang membekali pengetahuan dan pemahaman kaidah berkehidupan bermasyarakat dengan mengedepankan penguasaan topik utama yaitu, Manajemen Sumber Daya Manusia; Sistem perencanaan SDM; Desain Pekerjaan dan Analisis Pekerjaan; Penarikan SDM; Pengembangan SDM (karier promosi, pemindahan); Kompensasi; Hubungan Serikat Karyawan.

\section{B. Sub Materi 2: Konsep Dasar Manajemen SDM}

1. Secara etimologis MSDM

a. Merupakan Penggabungan dua konsep yang maknanya memiliki pengertian yang berbeda

b. Manajemen dan Sumber Daya Manusia

Manajemen-->Proses POAC serta proses penggunaan sumber-sumber daya organisasi untuk mencapai tujuannya

2. Sumber daya Manusia (SDM)-->

a. Merupakan daya (tenaga/power/kekuatan) yang bersumber dari manusia

b. Potensi manusiawi yang melekat keberadaannya pada seseorang yang meliputi potensi:

1) Potensi fisik : kemampuan fisik yang terakumulasi pada seseorang (pegawai/anggota organisasi)

2) Potensi non fisik: Kemampuan seseorang (pengetahuan, intelegensia, keahlian)

\section{Pengertian MSDM}

a. Manajemen Sumber Daya Manusia (MSDM) adalah pemafaatan para individu untuk mencapai tujuan-tujuan organisasi. (Mondy 2008) 
b. Tujuan manajemen sumber daya manusia adalah meningkatkan kontribusi produktif para karyawan bagi organisasi secara stratejik, etis, dan bertanggung jawab sosial. (Werther \& Davis 1996)

c. SDM adalah aset yang harus dikelola secara cermat dan sejalan dengan kebutuhan organisasi. (Schuler \& Jackson 2006)

\section{Sub Materi 3: Mengelola Sumber Daya Manusia}

a. Salah satu aspek yang tidak kalah pentingnya untuk dikelola para wirausahawan adalah sumber daya manusia ( SDM ) yang dimilikinya.

b. Manusia ( karyawan ) yang menjadi motor penggerak kegiatan usaha perlu dikelola secara profesional.

\section{Sub Materi 4: Ruang lingkup manajemen SDM}

RUANG LINGKUP MANAJEMEN SUMBER DAYA MANUSIA SECARA HOLISTIK

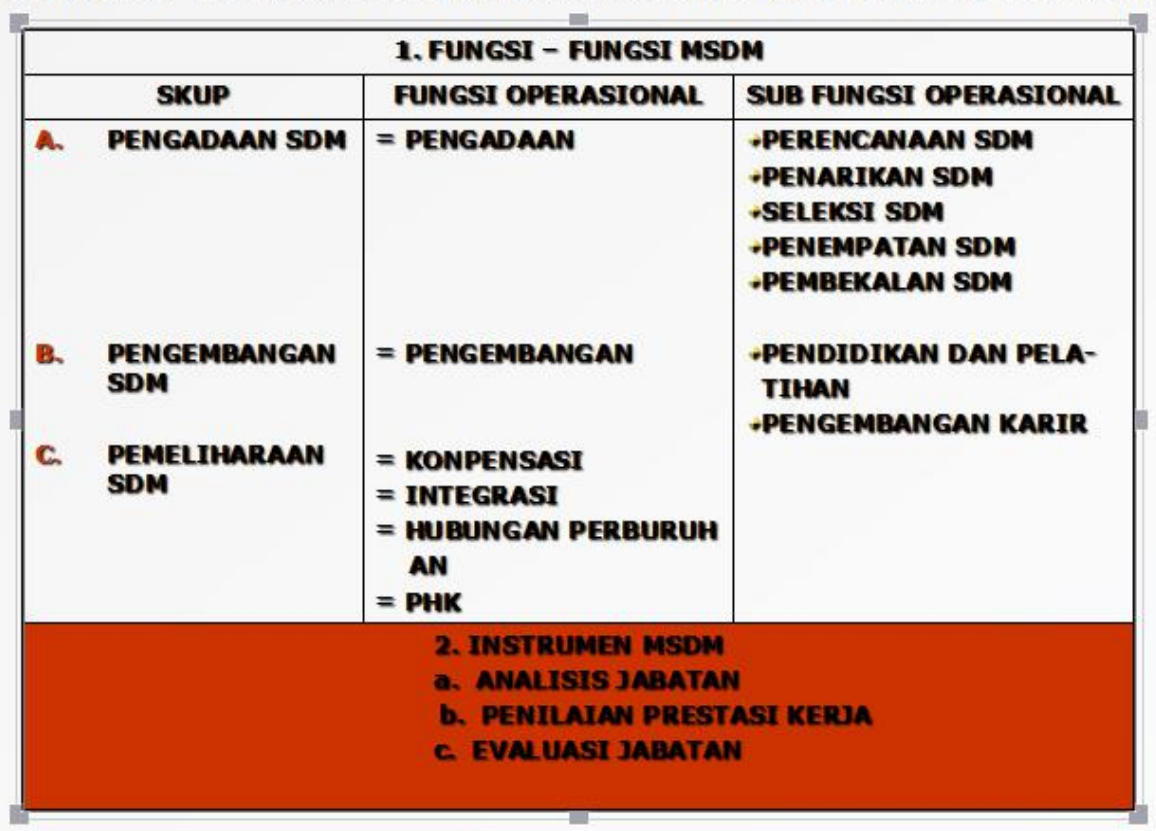

Gambar 1.1 Ruang Lingkup Manajemen SDM

\section{Sub Materi 5: Tujuan-tujuan MSDM}

a. Tujuan organisasional

Memastikan bahwa MSDM berkontribusi pada efektivitas organisasional.

Departemen SDM membantu para manajer untuk mencapai tujuan-tujuan organisasi. Dalam hal ini para manajer tetap bertanggung jawab penuh atas 
para bawahannya, departemen SDM hanya memberikan dukungan dalam hal-hal yang terkait dengan pengelolaan SDM.

b. Tujuan Fungsional

Menjaga kontribusi departemen SDM dalam tingkat yang layak bagi kebutuhan-kebutuhan organisasi. Sumber-sumber daya akan terbuang percuma jika MSDM tidak direncanakan secara optimal sesuai kebutuhan organisasi.

c. Tujuan kemasyarakatan

Bersikap etis dan bertanggung jawab sosial terhadap kebutuhan-kebutuhan dan tantangan-tantangan masyarakat sembari meminimalkan dampak negatif tuntutan-tuntutan tersebut bagi organisasi.

d. Tujuan personal

Membantu para karyawan mencapai tujuan-tujuan pribadi mereka sejauh tujuan-tujuan mendorong kontribusi individual bagi organisasi. Tujuan personal para karyawan akan tercapai jika para karyawan dipelihara, dipertahankan, dan dimotivasi. Jika tidak demikian, kinerja dan kepuasan karyawan akan menurun dan karyawan bisa meninggalkan organisasi.

\section{Sub Materi 6: Profesi dalam SDM}

Profesi pada umumnya mempunyai beberapa ciri, yaitu :

a. Memberikan pelayanan (service) pada orang segera langsung (yang umumnya bersifat konfidental).

b. Menempuh pendidikan tertentu dengan melalui ujian tertentu sebelum melakukan pelayanan.

c. Anggotanya yang relatif homogen.

d. Menerapkan standar pelayanan tertentu.

e. Etik profesi yang ditegakkan oleh suatu organisasi profesi.

\section{Sub Materi 7: Kaidah-kaidah pokok etika profesi sebagai berikut :}

a. Profesi harus dipandang dan dihayati sebagai suatu pelayanan, sehingga sifat tanpa pamrih menjadi cirri khas dalam mengemban profesi. Artinya, pertimbangan yang menentukan dalam pengambilan keputusan adalah kepentingan pasien atau klien serta kepentingan umum, dan bukan kepentingan pengemban profesi sendiri. 
b. Pelayanan professional dalam mendahulukan kepentingan pasien atau klien mengacu pada kepentingan atau nilai-nilai luhur sebagai norma kritik yang memotivasi sikap dan tindakan.

c. Pengembanan profesi harus selalu mengacu pada masyarakat sebagai keseluruhan.

d. Agar persaingan dalam pelayanan berlangsung secara sehat sehingga dapat menjamin mutu dan peningkatan mutu pengemban profesi harus bersemangatkan solidaritas anatar sesama rekan seprofesi.

\section{Sub Materi 8: Kode etik}

adalah pedoman perilaku yang berisikan garis-garis besar. Kode etik harus memiliki sifat-sifat antara lain
(1) Harus rasional, tetapi tidak kering dari emosi
(2) harus konsisten, tetapi tidak kaku, dan
(3) harus bersifat universal.

\section{Sub Materi 9: Tantangan Kesehatan Masa Kini dan Masa Depan}

a. Globalisasi

b. Masyarakat Ekonomi ASEAN (MEE), APEC, AFTA

c. Masalah Lingkungan Hidup

d. Kemajuan yang sangat cepat dalam ICT

e. Konvergensi ilmu dan teknologi

f. Ekonomi berbasis pengetahuan

g. Pergeseran kekuatan ekonomi global

h. Kualitas, investasi dan transformasi pendidikan

i. Perkembangan jenis-jenis penyakit

\section{Indonesia Kini Memasuki MEA,} yang Memiliki 4 Ciri Utama:
a. Kawasan ekonomi yang sangat kompetitif
b. Daerah-daerah akan terintegrasi secara penuh dalamekonomi global
c. Memiliki wilayah pembangunan ekonomi yang merata
d. Basis dan produksi tunggal 
Tantangan SDM Indonesia di Era MEA

Kesiapan berperan dalam Masyarakat Ekonomi ASEAN (MEE) menuntut pengembangan kualitas SDM secara formal dan informal, sehingga mahasiswa sebagai potensi pekerja di masa datang akan memiliki kualifikasi yang lebih baik untuk mendukung dan berpartisipasi di era MEA.

Agenda 2030 pembangunan sustainable

a. Fokus pada ekologi: SDA dan kapasitas ekologis

b. Sistem-sistem ekonomi: Fokus pada ekonomi

c. Modal sosial dan tujuan kesejahteraan: Fokus pada sosial

Sustainable development goals:

a. Social

b. Bearable

c. Equitable

d. Sustainable

e. Environment

f. Viable

g. Economic

\section{Sub Materi 11: Prinsip pelayanan kesehatan masa depan}

a. Transaksi lebih bermoral memenuhi kebutuhan siapa saja

b. Komprehensif berbasis kearifan lokal

c. Kepemimpinan yang kuat

d. Orientasi pelayanan humanistic (Orang miskin perhatikan)

e. Pelayanan terkoordinasi berbagai jenjang (RSUP-RS regional RS-Yan Primer)

f. Quality Improvement \& safety

g. Akreditasi semua yankes secepatnya

h. Akses terbuka Glorekalisasi

i. Payment for added value

j. Pelayanan yang menyehatkan 
Transformasi yang dibutuhkan:

a. Evidence Based Health Policy untuk quality leveling/ continuous quality improvement

b. Pemanfaatan data/informasi untuk keputusan-keputusan stakeholders

1) Manajemen \& Layanan

2) Keberdayaan klien

3) Jejaring dan teamwork 


\section{MATERI 2}

\section{Pengantar Manajemen SDM}

\section{A. Sub Materi 1: SWOT Analysis}

Analisis SWOT akan memberikan informasi kepada manajer mengenai dimana posisi organisasi dalam persaingan. Analisis lingkungan usaha dan peluang pasar secara kuantitatif akan membantu identifikasi peluang dan ancaman yang dihadapi oleh RS anda. Analisis kinerja internal akan membantu mengidentifikasi kekuatan dan kelemahan RS anda (Basis for Establishing long-range objectives).

Contoh:

Strength: Alat laser baru , Komunitas senam lansia, Kunjungan di Klinik Saraf/kasus stroke meningkat

Weakness: SpS dokter tamu

Opportunity: Stroke urutan ke 3, prevalensi 5\%, Piramida penduduk dewasa, Belum ada RS yang mengembangkan Unit Stroke terintegrasi

Threat: Masyarakat lebih percaya sangkal putung

\section{B. Sub Materi 2: Strategi Formulasi Pelayanan Jasa}

1. Kebijakan=Solusi

Anderson (2006: 6), kebijakan dapat didefinisikan sebagai tindakan yang didesain secara sengaja yang relatif stabil yang dilakukan oleh aktor sebagai tindakan yang didesain secara sengaja yang realtif stabil yang dilakukan oleh aktor atau sejumlah aktor untuk menyelesaikan masalah atau hal-hal yang menjadi perhatian bersama.

\section{Kebijakan dan Formulasi?}

Gerston (2002), hal penting dalam formulasi kebijakan adalah bagaimana memberikan pemahaman mengenai akuntabilitas dari semua pembuat kebijakan adalah kepada masyarakat yang dilayaninya (Gerston, 2002: 14). 


\section{Apa Kriteria Formulasi Kebijakan?}

Anderson (2006, 127:137), 6 kriteria mempengaruhi suatu kebijakan tertentu:

a) nilai-nilai yang dianut baik oleh organisasi, profesi, individu, kebijakan maupun ideologi

b) afiliasi partai politik

c) kepentingan konstituen

d) opini publik

e) penghormatan terhadap pihak lain

f) aturan kebijakan

\section{Tahapan Formulasi Kebijakan}

a) Proses 1

Identifikasi masalah aktivitas; publikasi masalah sosial: mengekspresikan tuntutan akan tindakan pemerintahPeserta: media massa, kelompok kepentingan; inistiatif masyarakat; opini publik

b) Proses 2

Penetapan agenda aktivitas: menentukan mengenai masalah-masalah apa yang akan diputuskan; masalah apa yang akan dibahas/ditangani oleh pemerintah peserta: elit termasuk presiden dan kongres; kandidat untuk jabatan publik tertentu; media massa

c) Proses 3

Perumusan kebijakan aktivitas: pengembangan proposal kebijakan untuk menyelesaikan dan memperbaiki masalah peserta: pemikir; presiden dan lembaga eksekutif; komite kongres; kelompok kepentingan

d) Proses 4

Legitimasi kebijakan aktivitas: memilih proposal; mengembangkan dukungan untuk proposal terpilih; menetapkannya menjadi peraturan hukum; memutuskan konstitusionalnya peserta: kelompok kepentingan; presiden; kongres; pengadilan

e) Proses 5

Implementasi kebijakan aktivitas mengorganisasikan departemen dan badan; menyediakan pembiayaan atau jasa pelayanan; menetapkan pajakpeserta: presidan dan staf kepresidenan; departemen dan badan 
f) Proses 6

Evaluasi kebijakan aktivitas: melaporkan output dari program pemerintah; mengevaluasi dampak kebijakan kepada kelompok sasaran dan bukan sasaran; mengusulkan Peserta: departemen dan badan; komite pengawasan kongres; media massa; pemikir

\section{Siapa yang Terlibat?}

media massa, kelompok kepentingan; inistiatif masyarakat; opini publik elit termasuk presiden dan kongres; kandidat untuk jabatan publik tertentu; media massa

pemikir; presiden dan lembaga eksekutif; komite kongres; kelompok kepentingan

kelompok kepentingan; presiden; kongres; pengadilan

presiden dan staf kepresidenan; departemen dan badan

departemen dan badan; komite pengawasan kongres; media massa; pemikir

\section{Sub Materi 3: Sistem Kerja Pelayanan Jasa}

Sistem Pelayanan Kesehatan di Indonesia

Visi Pembangunan Kesehatan

Gambaran keadaan masyarakat Indonesia di masa depan atau Visi yang ingin dicapai melalui pembangunan kesehatan dirumuskan dalam INDONESIA

SEHAT 2025

1. Dalam Indonesia Sehat 2025,

a. Lingkungan strategis pembangunan kesehatan yang diharapkan adalah lingkungan yang kondusif bagi terwujudnya keadaan sehat jasmani, rohani maupun sosial

b. Perilaku masyarakat yang diharapkan dalam Indonesia Sehat 2025 adalah perilaku yang bersifat proaktif untuk memelihara dan meningkatkan kesehatan; mencegah risiko terjadinya penyakit; melindungi diri dari ancaman penyakit dan masalah kesehatan lainnya; sadar hukum; serta berpartisipasi aktif dalam gerakan kesehatan masyarakat, termasuk menyelenggarakan masyarakat sehat dan aman (safe community). 
c. Masyarakat memiliki kemampuan menjangkau pelayanan kesehatan yang bermutu dan juga memperoleh jaminan kesehatan

2. Untuk mewujudkan INDONESIA SEHAT 2025, ada empat misi pembangunan kesehatan

a. Menggerakkan Pembangunan Nasional Berwawasan Kesehatan.

b. Keberhasilan pembangunan kesehatan tidak semata-mata ditentukan oleh hasil kerja keras sektor kesehatan, tetapi sangat dipengaruhi pula oleh hasil kerja serta kontribusi positif berbagai sektor pembangunan lainnya.

c. Mendorong Kemandirian Masyarakat untuk Hidup Sehat.

d. Kesadaran, kemauan dan kemampuan setiap individu, keluarga dan masyarakat untuk menjaga kesehatan, memilih, dan mendapatkan pelayanan kesehatan yang bermutu, sangat menentukan keberhasilan pembangunan kesehatan.

\section{Sub Materi 4: Sistem Kesehatan Nasional}

Untuk menjamin tercapainya tujuan pembangunan kesehatan, diperlukan dukungan Sistem Kesehatan Nasional yang tangguh. Di Indonesia, Sistem Kesehatan Nasional (SKN) telah ditetapkan pada tahun 1982. SKN secara terus menerus mengalami perubahan sesuai dengan dinamika masyarakat

\section{Pengertian SKN}

Suatu tatanan yang menghimpun berbagai upaya bangsa Indonesia secara terpadu dan saling mendukung guna menjami derajat kesehatan yang setinggi-tingginya sebagai perwujudan kesejahteraan umum seperti dimaksud dalam Pembukaan UUD 1945.

Dari rumusan pengertian di atas, jelaslah SKN tidak hanya menghimpun upaya sektor kesehatan saja melainkan juga upaya dari berbagai sector lainnya termasuk masyarakat dan swasta. Sesungguhnyalah keberhasilan pembangunan kesehatan tidak ditentukan hanya oleh sektor kesehatan saja.

\section{Tujuan SKN}

Terselenggaranya pembangunan kesehatan oleh semua potensi bangsa, baik masyarakat, swasta maupun pemerintah secara sinergis, berhasil-guna dan 
berdaya-guna, sehingga tercapai derajat kesehatan masyarakat yang setinggi-tingginya.

\section{Maksud dan Kegunaan Sistem Kesehatan Nasional}

Penyusunan SKN dimaksudkan untuk dapat dipergunakan sebagai landasan, arah dan pedoman penyelenggaraan pembangunan kesehatan baik oleh masyarakat, swasta maupun oleh pemerintah (pusat, provinsi, kabupaten/kota) serta pihak pihak terkait lainnya.

4. Indikator pencapaian SKN ditentukan oleh dua determinan

a. Pertama, status kesehatan yakni yang menunjuk pada tingkat kesehatan yang berhasil dicapai oleh SKN yang dihitung dengan menggunakan disability adjusted life expectancy (DALE).

b. Kedua, tingkat ketanggapan (responsiveness) system kesehatan yakni yang menunjuk pada kemampuan SKN dalam memenuhi harapan masyarakat tentang bagaimana mereka ingin diperlakukan dalam memperoleh pelayanan kesehatan. Hasil yang diperoleh untuk indikator ini menempatkan Indonesia pada urutan ke 106 dari 191 negara anggota WHO yang dinilai.

\section{Indikator kinerja SKN}

a. Pertama, distribusi tingkat kesehatan di suatu negara ditinjau dari kematian Balita.

b. Kedua, distribusi ketanggapan (responsiveness) sistem kesehatan ditinjau dari harapan masyarakat.

c. Ketiga, distribusi pembiayaan kesehatan ditinjau dari penghasilan keluarga. Hasil yang diperoleh untuk indikator ini menempatkan Indonesia pada urutan ke 92 dari 191 negara anggota WHO yang dinilai

\section{Prinsip-Prinsip SKN}

a. Perikemanusiaan

b. Hak Asasi Manusia

c. Adil dan Merata

d. Pemberdayaan dan Kemandirian Masyarakat

e. Kemitraan 
f. Pengutamaan dan Manfaat

g. Tata kepemerintahan yang baik

7. SKN terdiri dari enam subsistem, yakni:

a. Subsistem Upaya Kesehatan (kuratif/rehabilitatif, promotif dan pencegahan)

b. Subsistem Pembiayaan Kesehatan

c. Subsistem Sumberdaya Manusia Kesehatan

d. Subsistem Obat dan Perbekalan Kesehatan

e. Subsistem Pemberdayaan Masyarakat

f. Subsistem Manajemen Kesehatan

8. Fungsi-Fungsi MSDM (Wherter \& Davis 1996)
a. Persiapan dan Seleksi
b. Analisis dan Desain Jabatan
c, Perencanaan SDM
d. Rekrutmen
e. Seleksi
f. Pengembangan dan Evaluasi
g. Orientasi, Penempatan, dan PHK
h. Pelatihan dan Pengembangan
i. Perencanaan Karir
j. Penilaian Kinerja

9. Fungsi-Fungsi MSDM (Wherter \& Davis 1996)
a. Kompensasi dan Proteksi
b. Upah/Gaji, Insentif, Tunjangan, dan Layanan
c. Keamanan, Keselamatan, dan Kesehatan
d. Hubungan Kekaryawanan dan Audit
e. Hubungan Kekaryawanan
f. Hubungan Serikat Pekerja-Manajemen
g. Audit MSDM

10. Fungsi-Fungsi MSDM (Mondy 2008)

a. Penyediaan Staf (Staffing) 
Penyediaan staf (staffing) merupakan proses untuk memastikan bahwa organisasi memiliki jumlah karyawan yang tepat dengan berbagai keahlian yang memadai untuk menjalankan pekerjaan-pekerjaan yang tepat, pada waktu yang tepat, untuk mencapai tujuan organisasi. Penyediaan staf mencakup:
1) Analisis jabatan
2) Perencanaan SDM
3) Perekrutan dan seleksi

\section{E. Sub Materi 5: Pengembangan Sumber Daya Manusia (Human Resource Development/HRD)}

Pengembangan SDM (human resource development/HRD) adalah fungsi utama MSDM yang tidak hanya terdiri atas pelatihan dan pengembangan namun juga aktivitas-aktivitas perencanaan dan pengembangan karir individu, pengembangan organisasi, serta manajemen dan penilaian kinerja.

\section{Kompensasi}

Kompensasi mencakup seluruh imbalan yang diberikan kepada karyawan sebagai penghargaan atas jasa mereka, yang meliputi:

a. Kompensasi finansial langsung: Bayaran yang diterima dalam bentuk gaji, upah, komisi, bonus, dsb.

b. Kompensasi finansial tidak langsung (tunjangan): Semua imbalan finansial yang tidak termasuk dalam kompensasi langsung seperti cuti dibayar, cuti sakit, liburan, asuransi kesehatan, dsb.

c. Kompensasi nonfinansial: Kepuasan yang diterima seseorang dari pekerjaan itu sendiri atau dari lingkungan psikologis dan/atau fisik di mana orang tersebut bekerja.

\section{Keselamatan dan Kesehatan}

Keselamatan adalah terlindunginya para karyawan dari luka-luka yang disebabkan kecelakaan yang berhubungan dengan pekerjaan.

Kesehatan adalah terbebasnya para karyawan dari penyakit fisik maupun emosional. 
Kedua aspek di atas penting karena para karyawan yang bekerja dalam lingkungan yang aman dan menikmati kesehatan yang baik akan cenderung lebih produktif dan memberikan manfaat jangka panjang bagi organisasi.

\section{Hubungan Kekaryawanan dan Perburuhan}

Seluruh bidang fungsional MSDM saling terhubung erat. Keputusan-keputusan di satu bidang akan memengaruhi bidang-bidang lainnya.

Beberapa contoh:

Merekrut calon-calon berkualitas terbaik hanya akan membuang waktu, tenaga, dan uang, jika kompensasi yang diberikan tidak bisa memotivasi karyawan.

Sistem kompensasi yang baik tidak akan efektif tanpa ditunjang lingkungan kerja yang aman dan sehat bagi para karyawan.

4. Lingkungan MSDM (Mondy 2008)

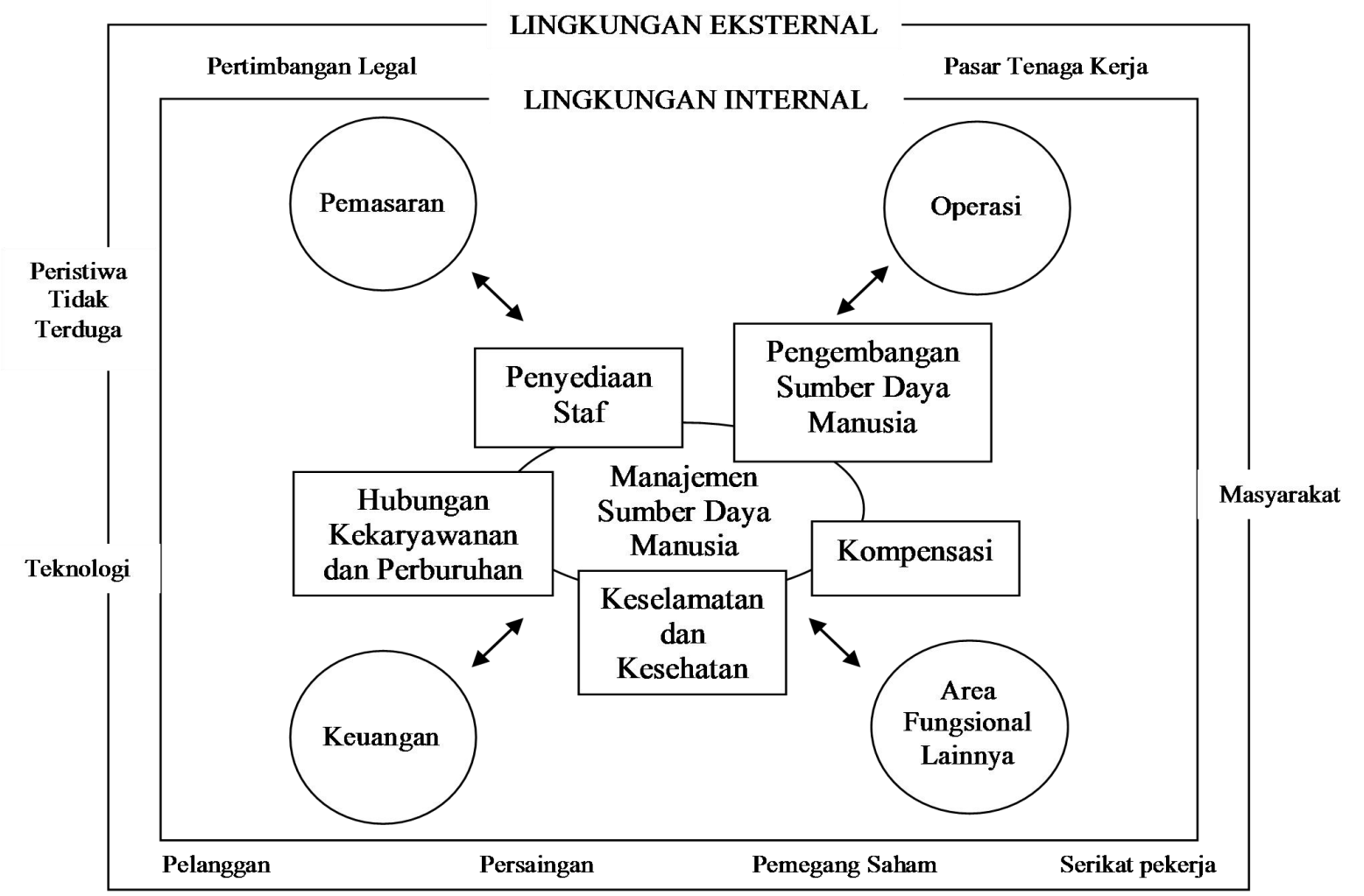

Gambar 2.1 Lingkungan MSDM

\section{Fungsi-Fungsi MSDM (Wherter \& Davis 1996)}

a. Persiapan dan Seleksi

b. Analisis dan Desain Jabatan 

c. Perencanaan SDM
d. Rekrutmen
e. Seleksi

\section{Pengembangan dan Evaluasi}
a. Orientasi, Penempatan, dan PHK
b. Pelatihan dan Pengembangan
c. Perencanaan Karir
d. Penilaian Kinerja

\section{Tugas-Tugas MSDM}

a. Perencanaan Sumber Daya Manusia, rekrutmen, dan seleksi

1) Melaksanakan analisis pekerjaan untuk menentukan pekerjaan-pekerjaan yang spesifik

2) Meramalkan sumber daya manusia yang dibutuhkan organisasi untuk mencapai sasaran

3) Mengembangkan dan mengiplementasikan rencana untuk memenuhi kebutuhan SDM tersebut

4) Rekrutmen Sumber Daya Manusia untuk Mencapai Sasarannya

5) Seleksi dan penempatan sumber daya manusia untuk mengisi pekerjaan tertentu di dalam

b. Pengembangan Sumber Daya Manusia

1) Orientasi dan Training Karyawan

2) Mendesain dan mengimplementasikan program pengelolaan pengembangan organisasional

3) Membangun tim yang efektif di dalam struktur organisasi

4) Mendesain sistem penilaian karyawan

5) Membantu Karyawan dalam rencana pengembangan karir

c. Kompensasi

1) Mendesain dan mengimplementasikan sistem kompensasi untuk semua karyawan

2) Menjamin keadilan dan konsistensi kompensasai 
d. Karyawan dan Hubungan Perburuhan

1) Melayani sebagai perantara antara organisasi dan serikat pekerja

2) Mendesain sistem disiplin dan menangani keluhan

e. Kesehatan dan Keselamatan Kerja

1) Mendesain dan mengimplementasikan untuk menjamin kesehatan dan keselatan kerja

2) Menyediakan bantuan untuk mengatasi persoalan pribadi karyawan yang berpengaruh pada pelaksanaan kinerjanya

f. Riset Sumber Daya Manusia

1) Menyediakan informasi sumber daya manusia

2) Mendesain dan mengimplementasikan sistem komunikasi karyawan

\section{F. Sub Materi 6: Permasalahan SDM}

1. Kesalahan penempatan orang dalam suatu pekerjaan

2. Turnover yang tinggi

3. Rendahnya kinerja karyawan dalam melaksanakan pekerjaan

4. Pembuangan waktu yang tidak efektif dalam melaksanakan pekerjaan

5. Diskriminasi dalam memperlakukan karyawan

6. Angka kecelakaan kerja yang tinggi

7. Ketidakadilan dalam pengupahan

8. Ketidakberdayaan karyawan 


\section{MATERI 3}

\section{Perencanaan SDM Kesehatan}

\section{A. Sub Materi 1: Arah Kebijakan}

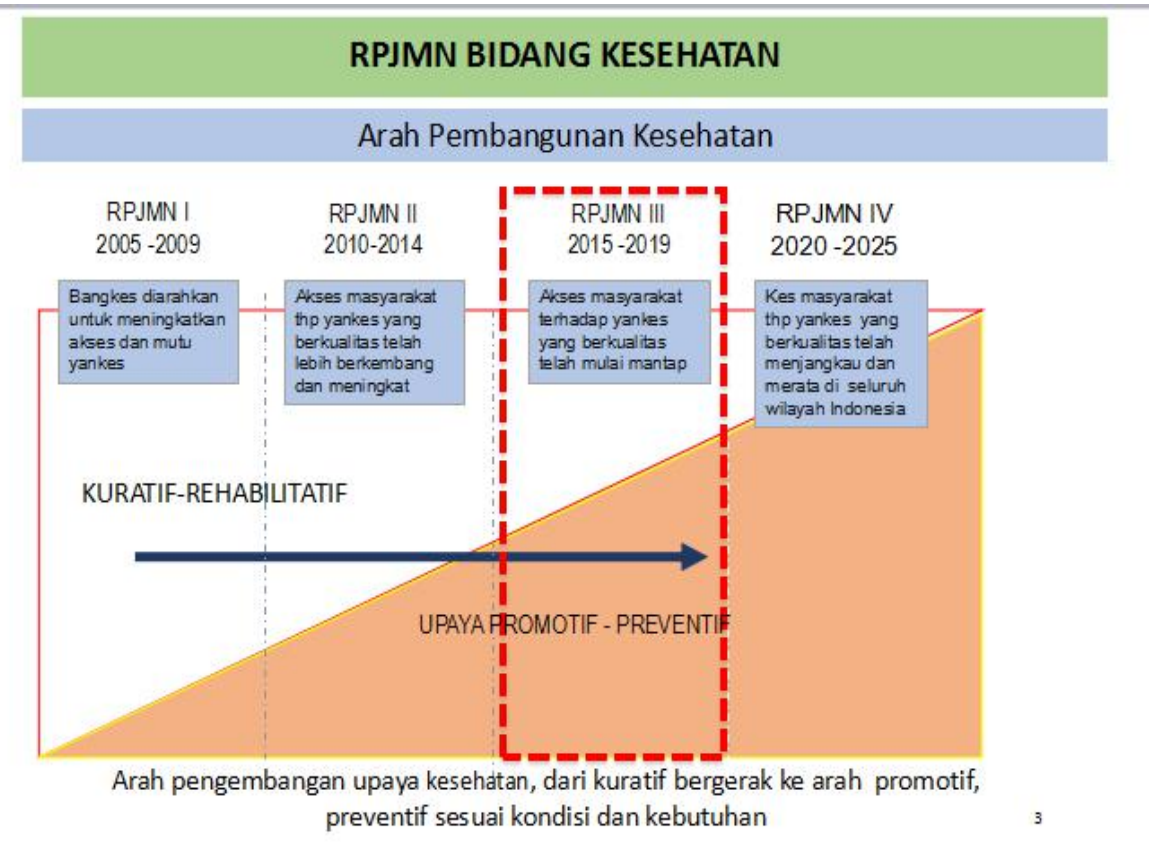

Gambar 3.1 RPJMN Bidang Kesehatan

1. Permasalahan SDM Kesehatan:

a. Jumlah tenaga kesehatan (Jenis tertentu masih kurang)

b. Distribusi tenaga kesehatan yang tidak merata

c. Mutu dan kualitas yang belum memadai (respon kekinian)

d. Kualifikasi tenaga kesehatan masih banyak yang belum DIII

2. Tugas Pemerintah dan Pemerintah Daerah (UU Nomor 36 Tahun 2014 Tentang Tenaga Kesehatan)

a. Pasal 13

Pemerintah dan Pemda wajib memenuhi kebutuhan tenaga kesehatan baik dalam jumlah, jenis dan kompetensinya

b. Pasal 27 ayat 3

Dalam hal terjadi kekosongan pemerintah dan pemda wajib menyediakan tenaga kesehatan pengganti 


\section{B. Sub Materi 2: Perencanaan dan Pendayagunaan SDM Kesehatan}

1. Perencanaan dan pemerataan nakes di fasyankes milik Pemda

a. Perencanaan dan Pemerataan Tenaga Kesehatan di Fasilitas Pelayanan Kesehatan milik Pemerintah Daerah dilakukan terhadap Tenaga Kesehatan dengan memperhatikan:

1). jenis;

2). jumlah; dan

3). mutu Tenaga Kesehatan.

b. Jumlah dan Jenis Nakes disesuaikan dengan kebutuhan pelayanan kesehatan dan ketersediaan fasyankes milik pemda

c. Pemerataan Tenaga Kesehatan dilaksanakan melalui redistribusi dan distribusi

d. Redistribusi dan distribusi Tenaga Kesehatan harus dilakukan dengan memperhatikan ketersediaan sarana dan prasarana serta jenis Tenaga Kesehatan yang disesuaikan dengan kebutuhan pelayanan kesehatan

2. Pendekatan perencanaan kebutuhan tenaga kesehatan

a. Kebutuhan tenaga kesehatan berdasarkan ratio tenaga kesehatan terhadap proyeksi jumlah penduduk

b. Standar Kebutuhan Tenaga Minimal

1) Puskesmas (Permenkes No.75 tahun 2014)

2) Rumah Sakit (Permenkes No.56 Tahun 2014)

c. Analisis Beban Kerja Kesehatan (ABK-Kes)

3. Isu pemenuhan tenaga kesehatan

a. Permasalahan mendasar dalam ketenagaan adalah kurang meratanya persebaran tenaga kesehatan, terutama di DTPK

b. Masih ditemukan Puskesmas dan Rumah Sakit yang tidak lengkap Jumlah dan Jenis Tenaga Kesehatannya.

c. Masih dijumpai Puskesmas yang tidak ada Dokter

d. Masih ada Rumah Sakit yang mempunyai tenaga tetapi tidak disertai dengan peralatan yang lengkap.

e. Turn Over Tenaga Kesehatan di beberapa daerah tinggi, Retensi Tenaga Kesehatan rendah. 
f. Insentif Tenaga Kesehatan belum memadai

UU No 5 Tahun 2014

Pasal 6

UU No 36 Tahun 2014

Pasal 23 ayat (2)

UU No 36 Tahun 2014

Pasal 28 ayat (1)

UU No 36 Tahun 2014

Pasal 29 ayat (1)
- Pegawai ASN terdiri PNS dan PPPK

- Pengangkatan tenaga kesehatan melalui PNS, PPPK dan

Penugasan Khusus

- Wajib Kerja kepada tenaga kesehatan yang memenuhi kualifikasi akademik dan kompetensi

- Pemerintah dan/atau Pemda dpat menetapkan pola ikatan dinas

Gambar 3.2 Mekanisme pemenuhan SDM Kesehatan

4. Upaya pemenuhan SDM kesehatan oleh pemerintah

a. Puskesmas

1) Penugasan Khusus Berbasis Tim (Nusantara Sehat Team Based)

2) Penugasan Khusus Individu (Nusantara Sehat Individu)

b. Rumah sakit

1) Penugasan Khusus Individu di rumah sakit dalam pembahasan teknis operasional

2) Penugasan Khusus Residen

3) Wajib Kerja Dokter Spesialis

5. Dasar hukum perencanaan SDM Kesehatan

a. Keputusan Menteri Kesehatan

Nomor : 81/MENKES/SK/I/2004 Tentang Pedoman Penyusunan

Perencanaan Sumber Daya Manusia Kesehatan Di Tingkat Propinsi, Kabupaten/Kota Serta Rumah Sakit.

b. GARIS-GARIS BESAR HALUAN NEGARA TAHUN 1999-2004

c. Ketetapan MPR no. 4 tahun 1999

d. Undang-undang No. 23 tahun 1992 tentang Kesehatan (Lembaran Negara Tahun 1992 No. 100, Tambahan Lembaran Negara No. 3495); 
e. Undang-undang No. 22 tahun 1999 tentang Pemerintahan Daerah (Lembaran Negara Tahun 1999 No. 60, Tambahan Lembaran Negara No. 3839);

f. Peraturan Pemerintah No. 32 tahun 1996 tentang Tenaga Kesehatan (Lembaran Negara Tahun 1996 No. 49, tambahan Lembaran Negara No. 3637);

g. Peraturan Pemerintah No. 25 tahun 2000 tentang Kewenangan Pemerintah dan Kewenangan Propinsi sebagai daerah otonom (Lembaran Negara Tahun 2000 No.54, Tambahan Lembaran Negara No. 3952) ;

h. Peraturan Pemerintah No.8 tentang Perangkat Daerah;

i. Keputusan Menkes No. 850/MENKES/SK/V/2000 tentang Kebijakan Pengembangan Tenaga Kesehatan tahun 2000 - 2010;

j. Keputusan Menkes No. 1277/MENKES/SK/XI/2001 tentang Organisasi dan Tata Kerja Departemen Kesehatan;

k. Keputusan Menkes No. 004/MENKES/SK/I/2003 tahun 2003 tentang Kebijakan dan Strategi Desentralisasi Bidang Kesehatan;

1. Keputusan Menkes No. 1457/MENKES/SK/X/2003 tentang SPM bidang kesehatan di Kabupaten/Kota.

6. Pokok-pokok perencanaan SDM Kesehatan

a. Perencanaan kebutuhan pada tingkat institusi.

Kebutuhan SDM yg ada sarana pelayanan kesehatan seperti puskesmas, rumah sakit, poliklinik dan lain-lainnya.

b. Perencanaan kebutuhan SDM kesehatan pada tingkat wilayah

Kebutuhan SDM di tingkat wilayah (Propinsi/Kabupaten/Kota).

c. Perencanaan kebutuhan SDM kesehatan untuk Bencana.

Persiapan SDM Kesehatan saat prabencana, terjadi bencana, dan post bencana, termasuk pengelolaan kesehatan pengungsi.

7. Metode perencanaan kebutuhan SDM di unit kerja SDMK

a. Full time equivalent : waktu

$\mathrm{FTE}=\underline{\text { Jumlah beban kerja per tahun }}$

Target/jam x jumlah jam kerja/tahun 
b. Antrian : Jumlah antrian

Tingkat Kedatangan Rata-Rata (Arrival Rate Per Jam)

Jumlah Waktu Pelayanan / Kecepatan pelayanan (services rate)

Waktu Normal

PFD

Standar Waktu

Jumlah Kebutuhan Loket Pelayanan Pendaftaran Rawat Jalan

Jumlah Loket $=$ Arrival Rate : Service Rate

c. WISN (Work Load Indikator Staf Need) : beban kerja

1) Hari Kerja Efektif

2) Standar Beban Kerja

3) Standar Kelonggaran

4) Kuantitas Beban Kerja

8. Tujuan dan rencana strategis organisasi melalui penempatan

a. Orang yang tepat

b. Pada tempat yang tepat

c. Pada waktu yang tepat

d. Dengan keterampilan dan pendidikan yang benar

e. Dalam kelompok dengan skill mix yang sesuai

9. Unit Rekam Medis (URM)

a. Organisasi URM

1) Struktur Organisasi RS

2) Sub Bag Rekam Medis

3) Unit Kerja Rekam Medis

b. Metode pembagian kerja

1) Pembagian Shift Kerja

2) Beban Kerja Masing-masing Petugas

3) Target Kerja

4) Distribusi Pegawai 
c. Analisa jabatan unit rekam medis

Membuat Rincian Tugas-tugas yang dikerjakan oleh Petugas tertentu dalam suatu unit Kerja (Mencakup Tugas Pokok Petugas maupun Tugas Lain/Tambahan).

Tabel 3.1 Aktivitas unit rekam medis

\begin{tabular}{|c|l|c|}
\hline NO & \multicolumn{1}{|c|}{ URAIAN TUGAS UNIT RM PASIEN RJ BARU } & $\begin{array}{c}\text { WAKTU YANG } \\
\text { DIPERLUKAN }\end{array}$ \\
\hline 1 & Menyerahkan formulr data sosial pasien & $5 "$ \\
\hline 2 & Menunggu hasil isian form data sosil pasien & $120 "$ \\
\hline 3 & Wawancara dengan pasien untuk kelengkapan data pasien & $60 "$ \\
\hline 4 & Menyerahkan form jaminan (jika perlu) + nunggu & $120 "$ \\
\hline 5 & Entri data dalam kumputer + print & $60 "$ \\
\hline 6 & Membuat kartu berobat & $30 "$ \\
\hline 7 & Menyiapkan berkas RM yang baru & $60 "$ \\
\hline 8 & Mengirim berkas RM ke Poliklinik & $60 "$ \\
\hline 9 & Pencatatan ke dalam buku ekspedisi & $30 "$ \\
\hline 10 & asembling/perakitan & $45 "$ \\
\hline 11 & koding & $30 "$ \\
\hline 12 & indeks & $30 "$ \\
\hline 13 & Entri data dalam komputer & $30 "$ \\
\hline 14 & Pelaporan/statistik & $30 "$ \\
\hline 15 & sortir & $50 "$ \\
\hline 16 & penyimpanan & \\
\hline
\end{tabular}

\section{WISN (Workload Indicator Staff Need)}

Merupakan perhitungan kebutuhan SDM Kesehatan berdasarkan Indikator Beban Kerja. Metode baru Berdasarkan kerja yang nyata yang dilakukan oleh tenaga kesehatan (beban kerjanya).Dapat diterapkan pada semua kategori tenaga: Staf Medis; Staf Paramedis; Staf Non-medis.

a. Mengapa WISN?

1) Berguna untuk menghitung kebutuhan saat ini dan masa mendatang

2) Bermanfaat untuk membandingkan SDM Kes pada daerah atau fasilitas kesehatan yang berbeda 
3) Dapat melihat apa nakes bekerja sudah sesuai dengan profesinya atau tidak

4) Dapat mengidentifikasi seberapa besar beban kerja SDM Kesehatan

b. Langkah WISN

1) Menetapkan waktu kerja tersedia

2) Menetapkan unit kerja dan kategori SDM

3) Menyusun standar beban kerja

4) Menyusun standar kelonggaran

5) Perhitungan kebutuhan tenaga per unit kerja

c. Waktu kerja tersedia

$$
\mathrm{WKT}=[\mathrm{A}-(\mathrm{B}+\mathrm{C}+\mathrm{D}+\mathrm{E})] \times \mathrm{F}
$$

\section{Keterangan :}

$$
\begin{array}{ll}
\text { A }=\text { Hari Kerja } & \text { D = Hari Libur Nasional } \\
\text { B }=\text { Cuti Tahunan } & \text { E = Ketidak Hadiran Kerja } \\
\text { C }=\text { Pendidikan dan Pelatihan } & \text { F = Waktu Kerja }
\end{array}
$$

1) Hitung jumlah hari kerja setahun

2) Perkirakan jumlah libur umum, cuti tahunan dan ketidak hadiran dalam setahun

3) Kurangkan hari kerja setahun dengan jumlah hari tidak masuk kerja

\section{Contoh:}

Ada 260 hari kerja setahun. Seorang perawat puskesmas tidak masuk 40 hari jadi hari kerjanya adalah 220 hari setahun

\section{d. Standar pekerjaan}

Waktu yang diperlukan seorang anggota kategori tenaga tertentu yang terdidik dan terlatih dengan baik serta memiliki motivasi yang baik untuk melaksanakan kegiatan sesuai dengan standar profesi dan keadaan di daerah tersebut. (untuk Standar Tugas Pokok) 
e. Standar beban kerja

Jumlah waktu yang digunakan seseorang untuk bekerja (dalam satu kegiatan) dalam setahun (jam/tahun) menjadi Rata2 waktu/kegiatan

Bila Standar beban kerja dinyatakan dalam unit waktu :

$$
\text { Standar Beban Kerja }=\frac{\text { WKT satu tahun }}{\text { Unit waktu untuk kegiatan tertentu }}
$$

Apabila Standar Pelayanan dinyatakan dalam kecepatan kerja :

Standar Beban Kerja $=W K T$ setahun $x$ kecepatan

f. Standar kelonggaran

Standar waktu kerja untuk tugas tambahan/ lainnya (kegiatan yang tidak dilaporkan dalam pelaksanaan tugas pokok), Misal kegiatan : Pencatatan dan pelaporan; Menghadiri pertemuan; Mengikuti pelatihan; Menyiapkan pelatihan.

Standar kelonggaran $=\underline{\text { rata }- \text { rata } \text { waktu per faktor kelonggaran }}$

Waktu kerja tersedia

g. Kuantitas beban kerja

Jumlah total tiap tugas/pekerjaan yang dilakukan dalam satu tahun

h. Rasio kebutuhan SDM

Kebutuhan tenaga kerja $=$ kuantitas kegiatan pokok + standar kelonggaran Standar beban kerja

Rasio : Jumlah Staff Tersedia : Jumlah Staff dibutuhkan

Ratio

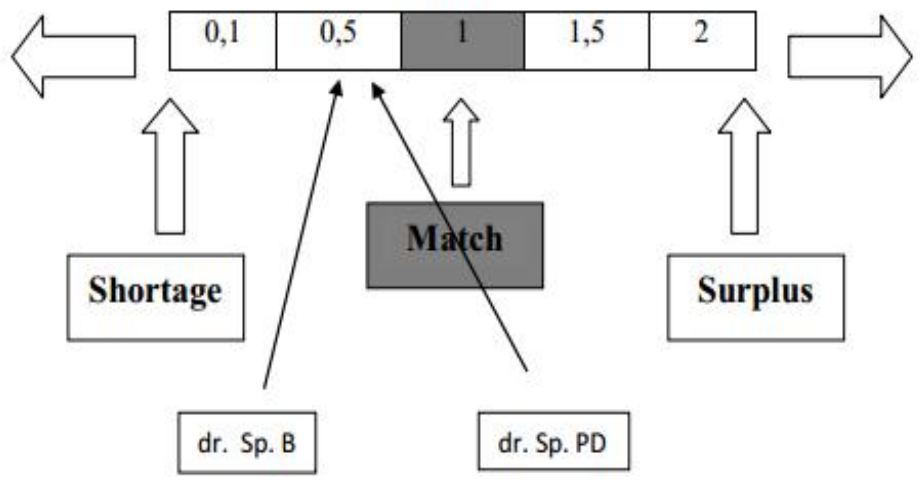




\section{Sub Materi 3: Postur Anggaran}

•Kegiatan Utama Kemkes antara lain:

-Penyediaan Vaksin Rp 2,663,7 M

- Penyediaan Obat dan Perbekalan kesehatan Ibu dan Anak, Penyakit Tropis Terabaikan, TB dan HIV/AIDS, dan Malaria Rp 1.936,2 M

-Program Pencegahan dan Pengendalian Penyakit Rp $1.644,95 \mathrm{M}$

-Program Strategis SDM Kesehatan Rp 1.464,9 M

- Pemberian Makanan Tambahan (PMT) Ibu Hamil Kurang Energi Kronis (KEK) dan Balita Kekurangan Gizi Rp 936,6

$\mathrm{M}$

-Penelitian dan Pengembangan Kesehatan Rp 662,1 M

-Peningkatan Kesehatan Jemaah Haji Rp 343,4 M

-RS Unit Pelaksana Teknis (UPT) Kawasan Indonesia

Timur (Maluku) Rp 250,0 M Kegiatan lainnya Rp 2.877,35

M
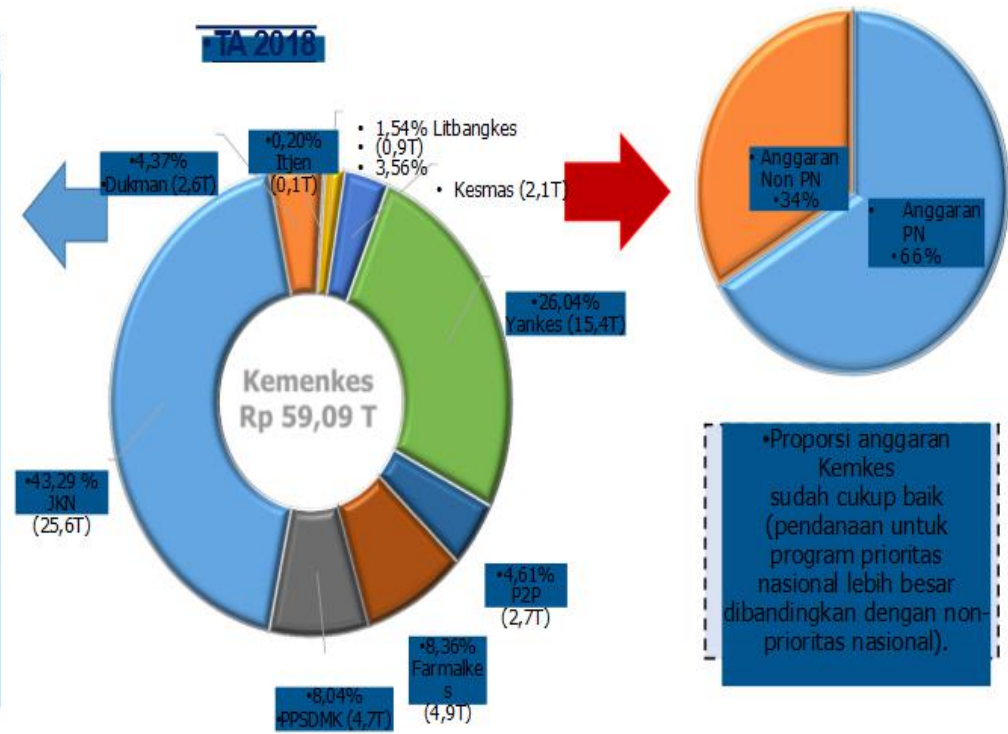

Gambar 3. 3 Anggaran Kemenkes TA 2018

\section{Sub Materi 4: Forecasting SDM}

Tabel 3.2 Kebutuhan dan kekurangan tenaga kesehatan di rumah sakit umum milik kementerian kesehatan dan pemerintah daerah tahun 2014, 2019 dan 2025

\begin{tabular}{|r|l|r|r|r|r|r|r|}
\hline \multirow{2}{*}{ NO } & \multirow{2}{*}{ Jenis Tenaga } & \multicolumn{2}{|c|}{2014} & \multicolumn{2}{|c|}{2019} & \multicolumn{2}{|c|}{2025} \\
\cline { 3 - 8 } & & Kebutuhan & Kekurangan & Kebutuhan & Kekurangan & Kebutuhan & Kekurangan \\
\hline 1 & Dokter Spesialis & 8,626 & 1,792 & 18,109 & 10,561 & 23,422 & 8,029 \\
\hline 2 & Dokter Umum & 4,183 & - & 7,299 & 3,639 & 10,284 & 4,080 \\
\hline 3 & Dokter Gigi & 978 & - & 1,785 & 929 & 2,524 & 1,007 \\
\hline 4 & Keperawatan & 60,022 & - & 140,137 & 87,618 & 183,684 & 64,568 \\
\hline 5 & Apoteker & 1,622 & - & 3,038 & 1,619 & 4,054 & 1,472 \\
\hline 6 & Asisten Apoteker & 3,244 & - & 6,076 & 3,238 & 8,108 & 2,943 \\
\hline 7 & SKM & 967 & - & 1,748 & 902 & 2,480 & 994 \\
\hline 8 & Sanitarian & 978 & - & 1,785 & 929 & 2,524 & 1,007 \\
\hline 9 & Gizi & 978 & - & 1,785 & 929 & 2,524 & 1,007 \\
\hline 10 & Keterapian Fisik & 2,418 & 889 & 4,479 & 2,363 & 6,504 & 2,697 \\
\hline 11 & Keteknisian Medis & 4,879 & - & 20,119 & 15,850 & 34,682 & 17,581 \\
\hline
\end{tabular}

Catatan: Kebutuhan merupakan perhitungan dengan menggunakan standar ketenagaan pada fasilitas kesehatan. 


\section{MATERI IV}

\section{Job Analysis dan Elemen Desain Pekerjaan}

\section{A. Sub Materi 1: Analisis Jabatan}

Definisi : Suatu proses berpikir yang bersifat abstrak mengenai suatu pekerjaan

(Nawawi, 2000)

1. Deskripsi dan spesifikasi persyaratan jabatan

DESKRIPSI DAN SPESIFIKASI/PERSYARATAN JABATAN ( BAMBANG WAHYUDI, 1996)

\begin{tabular}{|c|c|}
\hline $\begin{array}{l}\text { DESKRIPSI JABATAN } \\
\text { GAMBAAN SECARA SINGKAT, CERMAT DAN TELIT } \\
\text { MENGENAI FUNGSI, TUGAS, WEWENANG, } \\
\text { TANGGUNGJAWAB DAN HUBUNGAN DARI SUATU } \\
\text { JABATAN TERTENTU }\end{array}$ & 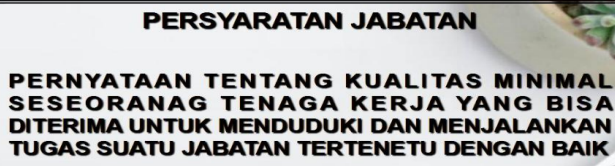 \\
\hline ISI JABATAN & ISI SPESIFIKASI JABATAN \\
\hline $\begin{array}{l}\text { 1. IDENTIFIKASI JABATAN } \\
\text { A. NAMA JABATAN } \\
\text { B. NAMA JABATAN PADANAN } \\
\text { C. KODE JABATAN } \\
\text { SIFAT JABATAN } \\
\text { A. URAIAN JABATAN } \\
\text { B. WEWENANG } \\
\text { C. HUBUNGAN DENGAN JABATAN } \\
\text { D. SUPERVISI YANG DIPERLUKAN } \\
\text { E. PERALATAN/MESIN YANG DIGUNAKAN } \\
\text { F. KONDISI KERJA } \\
\text { TENTANG KUALIFIKASI } \\
\text { T. KUALIFIKASI UMUM } \\
\text { B. KUALIFIKASI KHUSUS }\end{array}$ & $\begin{array}{l}\text { 1. } \\
\text { SYARAT UMUM } \\
\text { A. PENDIDIKAN } \\
\text { B. PENGALAMAN } \\
\text { 2. SYARAT KHUSUS } \\
\text { A. KONDDISI FISIK I PSIKHIS } \\
\text { B. JENIS KELAMIN } \\
\text { C. MINAT DAN BAKAT }\end{array}$ \\
\hline
\end{tabular}

Gambar 4.1 Deskripsi dan persyaratan jabatan

2. Prinsip dan prosedur analisis jabatan

PRINSIP DAN PROSEDUR ANALISIS JABATAN

\begin{tabular}{|c|c|}
\hline $\begin{array}{c}\text { PRINSIP } \\
\text { ANALISIS JABATAN }\end{array}$ & $\begin{array}{c}\text { PROSEDUR } \\
\text { ANALISIS JABATAN }\end{array}$ \\
\hline $\begin{array}{l}\text { 1. } \\
\text { HARUS DITENTUKAN SECARA JELAS } \\
\text { JATAS- BATAS PEKERJAAN DALAM } \\
\text { JABATAN, HAL INI ADA DALAM } \\
\text { JABATAN } \\
\text { HARUS BERDASARKAN ATAS KENYA- } \\
\text { TAAN SEBENARNYA (OBYEKTIF) } \\
\text { MENGGUNAKAN DATA, BERKAITAN } \\
\text { DENGAN WEWENANG YANG ADA, } \\
\text { SUBYEKTIF PRIBADI DIHINDARKAN } \\
\text { 3. PROSES KEGIATAN DALAM JABATAN } \\
\text { ITU HARUS DISUSUN SECARA KRONO- } \\
\text { LOGIS } \\
\text { MEMPERHATIKAN SITUASI PEKER- } \\
\text { JAAN }\end{array}$ & $\begin{array}{l}\text { 1. PENENTUAN TUJUAN ANALISIS } \\
\text { 2. PABATAN } \\
\text { 3. PERENCANAAN ANALISIS JABATAN } \\
\text { 4. PENGOLAHAN DATA JABATAN } \\
\text { 5. PENYAJIAN HASIL ANALISIS JABATAN } \\
\text { 6. PENYUSUNAN PROGRAM MSDM } \\
\text { LAINNYA }\end{array}$ \\
\hline
\end{tabular}

Gambar 4.2 Deskripsi dan persyaratan jabatan 


\section{Rekrutmen/penarikan}

Rekrutmen adalah usaha mencari dan mempengaruhi tenaga kerja agar mau melamar lowongan pekerjaan yang ada dalam suatu perusahaan.

a. Pendekatan yang digunakan

1) Prospecting theory of recruitment

2) Mating theory of recruitment

b. Rekrutmen

1) Sumber: Internal dan eksternal

2) Dasar: Job spec dan PP

3) Metode : Tertutup dan terbuka

4) Kendala: Internal dan eksternal

c. Sumber-sumber tenaga kerja

1) Internal

2) Eksternal

a) Kantor penempatan tenaga kerja

b) Lembaga pendidikan

c) Referensi karyawan

d) Serikat buruh

e) Pencangkokan

f) Nepotisme

g) Pasar tenaga kerja

3) Keputusan penarikan

Bergantung pada keuntungan dan kerugian atau kelemahan dari masing-masing sumber penarikan tenaga kerja

d. Faktor-faktor yang mempengaruhi rekrutmen (Hasibuan, 2000)

1) Balas jasa yang diberikan

2) Status karyawan tetap/honor

3) Kesempatan promosi

4) Persyaratan pekerjaan

5) Metode penarikan 
6) Soliditas perusahaan

7) Peraturan perburuhan

8) Penawaran tenaga kerja

e. Evaluasi rekrutmen

1) Jumlah pelamar

2) Jumlah penawaran

3) Jumlah tenaga kerja yang diterima

4) Jumlah penempatan tenaga kerja yang tepat

f. Proses seleksi pegawai

Aplikan $\rightarrow \quad$ treatmen untuk menjadi karyawan $\quad \rightarrow \quad$ proses seleksi

$\rightarrow \quad$ Rangkaian langkah-langkah spesifik yang digunakan untuk membuat keputusan. Proses dimulai ketika pelamar mengajukan lamaran, dengan proses akhir berupa keputusan.

g. Penilaian kinerja

Adalah perbandingan antara pegawai, proses bekerja dan prestasi kerja dengan perusahaan, proses penilaian, dan standar prestasi yang kemudian hasilnya di tentukan apakah bawah standar, sesuai standar atau di atas standar

h. Ruang lingkup penilaian kinerja

1) Who?

2) Why?

3) What?

4) When?

5) Where?

6) How?

i. Mengelola karyawan

1) Motivasi karyawan diharapkan dapat meningkatkan kepuasan kerja karyawan yang pada akhirnya dapat meningkatkan kinerja perusahaan 
2) Merekrut, melatih dan mengevaluasi karyawan dilakukan dengan perekrutan karyawan yang sesuai, pelatihan karyawan yang sesuai dan evaluasi karyawan yang sesuai, yang pada akhirnya dapat meningkatkan kinerja perusahaan.

\section{B. Sub Materi 2: Perbedaan MSDM dan manajemen personalia}

Dalam istilah "manajemen personalia" terkandung pengertian bahwa karyawan (personalia) hanya dianggap sebagai salah satu faktor produksi saja, yang tenaganya harus digunakan secara produktif bagi pencapaian tujuan perusahaan. Sedangkan dalam istilah MSDM terkandung pengertian bahwa karyawan (SDM) yang ada dalam perusahaan merupakan aset (kekayaan, milik yang berharga) perusahaan, sehingga harus dipelihara dan dipenuhi kebutuhannya dengan baik.

\section{Manajemen sumber daya manusia}

Sebagai suatu kegiatan merencanakan, mengarahkan, dan mengkoordinasikan semua pekerjaan yg menyangkut pegawai, mencari pegawai, melatih atau untuk mencapai tujuan organisasi secara efisien dan memungkinkan pegawai menggunakan segala kemampuannya, minatnya dan kesempatan untuk bekerja sebaik mungkin

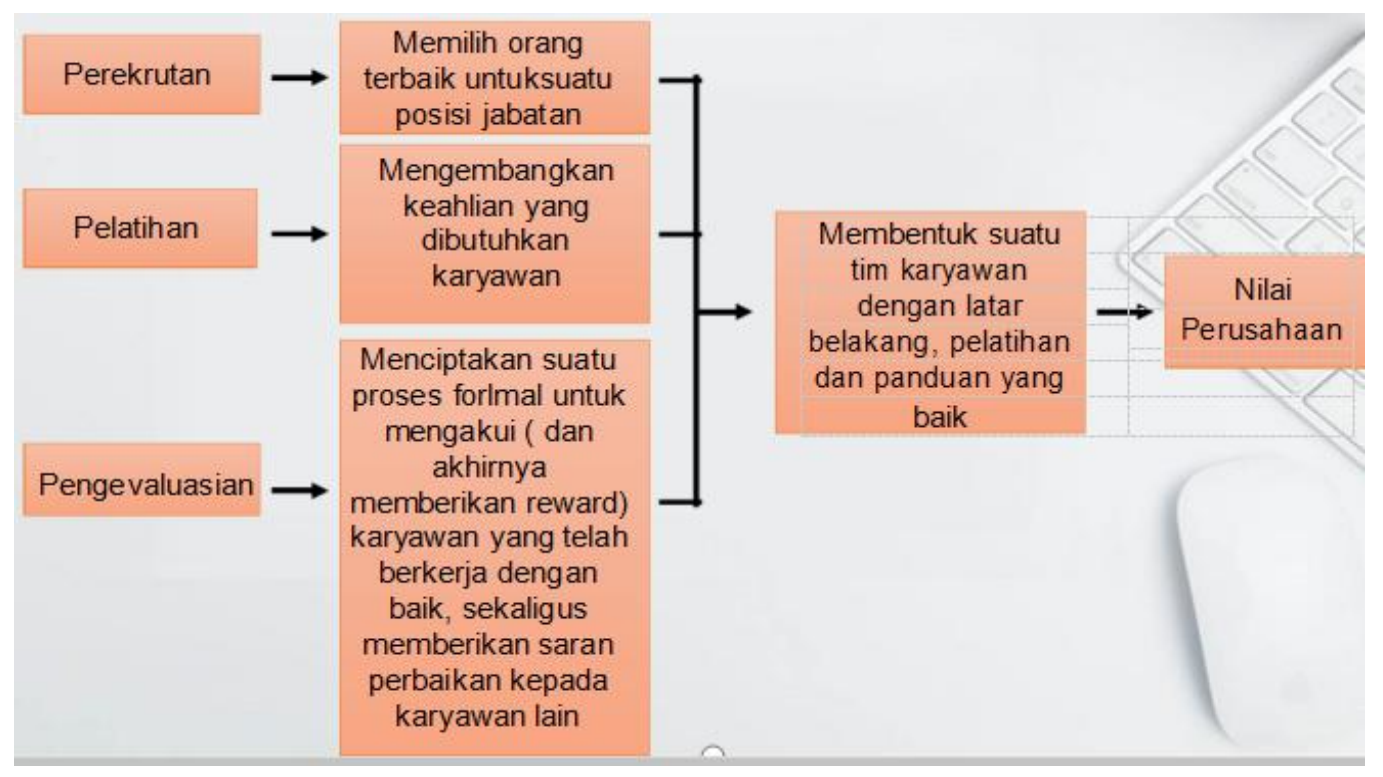

Gambar 4.3 Merekrut, melatih, dan mengevaluasi karyawan 


\section{Sub materi 3: Perencanaan Sumber Daya Manusia}

Aktivitas perencanaan untuk memuaskan kebutuhan perusahaan atas pekerja, terdapat 3 tugas: meramalkan kebutuhan tenaga kerja, analisis pekerja dan perekrutan.

1. Meramalkan kebutuhan tenaga kerja

Menentukan jumlah yang tepat atas kualifikasi orang-orang dan dimana mereka dibutuhkan. Terdapat 3 peristiwa yang dusyaratkan atas perkiraan tersebut:

a) Firm expansion

b) Pengunduran diri/expansion

c) Temporary increase in production

\section{Analisis Kerja}

Analisis yang digunakan untuk menentukan tugas dan surat kepercayaan yang diperlukan untuk posisi tertentu. Hasil job analisis adalah :

a) Job specification

Identifikasi berbagai keterampilan yang diperlukan, ciri atau atribut untuk kesuksesan performance sebuah pekerjaan tertentu.

b) Job description

Uraian tugas dan tanggung jawab posisi pekerjaan (job description)

\section{Perekrutan}

Meliputi pencarian dan menarik individu yang berkualitas yang dapat dipilih.

a. Internal : Merekrut karyawan di dalam perusahaan

b. Eksternal : Merekrut karyawan di luar perusahaan

\section{Sub Materi 4: Kompensasi}

1. Kompensasi mencakup seluruh imbalan yang diberikan kepada karyawan sebagai penghargaan atas jasa mereka, yang meliputi:

a. Kompensasi finansial langsung: Bayaran yang diterima dalam bentuk gaji, upah, komisi, bonus, dsb.

b. Kompensasi finansial tidak langsung (tunjangan): Semua imbalan finansial yang tidak termasuk dalam kompensasi langsung seperti cuti dibayar, cuti sakit, liburan, asuransi kesehatan, dsb. 
c. Kompensasi nonfinansial: Kepuasan yang diterima seseorang dari pekerjaan itu sendiri atau dari lingkungan psikologis dan/atau fisik di mana orang tersebut bekerja.

2. Tujuh metode kompensasi
a. Gaji dan upah
b. Pilihan persediaan
c. Komisi
d. Bonus
e. Bagi hasil
f. Imbalan kerja
g. Penghasilan tambahan

3. Insentif-insentif individu

a. Bonus

Insentif kinerja perorangan dalam bentuk pembayaran khusus

b. Komisi

Kompensasi untuk mencapai target penjualan tertentu.

c. Sistem Penggajian Prestasi (Merit salary system)

Program insentif yang menghubungkan kompensasi terhadap kinerja dalam pekerjaan nonpenjualan.

d. Pembayaran atas Kinerja (pay for performance) atau Pembayaran variabel (variable pay). Insentif perorangan yang diberikan kepada seorang manager terutama untuk output yang produktif

4. Insentif di keseluruhan perusahaan

a. Rencana Upah Bagi Laba (Profit sharing plans)

Program insentif yang membagikan bonus kepada karyawan apabila laba perusahaan diatas tingkat tertentu.

b. Rencana Upah Bonus (gain sharing plans)

Program insentif yang membagikan bonus kepada karyawan yang kinerjanya memperbaiki produktivitas.

c. Rencana Upah Atas Pengetahuan (Pay for knowledge) 
Program insentif untuk mendorong para karyawan mempelajari ketrampilan baru atau menjadi ahli dalam pekerjaan yang berbeda.

5. Tunjangan/benefit

a. Kompensasi selain upah dan gaji yang ditawarkan perusahaan kepada para karyawannya.

b. Asuransi Kompensasi pekerja (worker's compensation insurance)

Asuransi legal untuk mengkompensasikan pekerja yang terluka sewaktu melaksanakan pekerjaan.

c. Bentuk-bentuk tunjangan :

Pembayaran masa liburan; Kesehatan; Asuransi kesehatan; Kematian atau gigi; Program pensiun; Perumahan, kendaraan; Pendidikan.

\section{E. Sub Materi 5: Pengelolaan Karyawan}

1. Pengembangan keahlian karyawan

a. Teknis

b. Pembuatan Keputusan

c. Pelayanan Pelanggan

d. Keselamatan

e. Hubungan Manusia

2. Evaluasi kinerja karyawan

Menjadi bagian oleh kriteria yang relevan untuk masing-masing posisi pekerjaan.

a. Memberikan Umpan Balik.

b. Memberikan Arahan.

c. Tunjukan Kekuatan dan Kelemahan.

d. Menentukan kenaikan gaji atau promosi.

e. Pertimbangkan kriteria yang obyektif dibandingkan subjektif.

3. Pengembangan keadilan evaluasi

a. Komunikasi tanggung jawab pekerjaan

b. Informasikan pekerja tentang inefisiensi

c. Gunakan konsistensi di antara pekerja 


\section{Desain pekerjaan}

Herjanto (2001) menjelaskan bahwa desain pekerjaan adalah rincian tugas dan cara pelaksanaan tugas atau kegiatan yang mencakup orang-orang yang mengerjakan tugas, cara tugas itu dilaksanakan, tempat tugas itu dikerjakan dan hasil apa yang diharapkan.

\section{Analisis pekerjaan}

Pengumpulan, penilaian, dan penyusunan informasi secara sistematis mengenai tugas-tugas dalam perusahaan, yang biasanya dilakukan oleh seorang ahli disebut job analyst. Informasi yang dikumpulkan secara lebih rinci meliputi tugas-tugas (duties), tanggung jawab (responsibility), kemampuan manusia (human ability), dan standar kinerja (performance standard).

6. Tujuan desain analisis pekerjaan
a. SDM yang handal
b. Nyaman dalam bekerja
c. Bermartabat dan Berkeadilan

7. Langkah-langkah dalam analisis pekerjaan
a. Menguji organisasi secara Keseluruhan dan Kecocokan tiap pekerjaan
b. Menentukan bagaimana Informasi analisis Pekerjaan akan digunakan
c. Memilih jenis pekerjaan untuk di teliti
d. Mengumpulkan data dengan teknik analisis pekerjaan yang dapat di terima
e. Menyiapkan deskripsi tugas
f. Menyiapkan spesifikasi pekerjaan

\section{Elemen-elemen pekerjaan}

Handoko (2000) menjelaskan bahwa elemen desain pekerjaan meliputi elemen organisasi ( pendekatan mekanik, aliran kerja dan praktik kerja), elemen lingkungan (tersedianya tenaga kerja yang potensial), dan elemen perilaku (otonomi, variasi tugas, identitas tugas dan umpan balik). 


\section{F. Sub Materi 6: Keperilakuan dan Efisiensi}

Pekerjaan tidak bisa dirancang hanya dengan menggunakan elemen-elemen yang mengarah efisiensi. Sebagai gantinya para perancang pekerjaan menggunakan riset perilaku untuk menyediakan suatu lingkungan pekerjaan yang membantu mencukupi kebutuhan individu. Efisiensi merupakan perbandingan antara keluaran dengan pemasukan. Unsur-unsur efisiensi akan membentuk spesialisasi yang tinggi, mengurangi perbedaan atau variasi, meminimumkan otonomi dan unsur-unsur kontradiktif lainnya.

1. Metode pengumpulan informasi analisis pekerjaan
a. Metode Wawancara
b. Metode Observasi
c. Metode Kuesioner
d. Metode Catatan Karyawan (Diary)
e. Metode Kombinasi

2. Tipe informasi yang dikumpulkan
a. Aktifitas yang berhubungan dengan pekerjaan
b. Teknologi/alat yang digunakan
c. Pelaksanaan pekerjaan
d. Aktifitas yang berorientasi pada karyawan
e. Persyaratan kepegawaian

3. Informasi yang dikumpulkan
a. Aktivitas pekerjaan
b. Perilaku manusia
c. Mesin, perangkat, peralatan, dan bantuan pekerjaan
d. Standar prestasi
e. Konteks pekerjaan
f. Persyaratan manusia 
4. Teknik rancang pekerjaan kelompok dan individu

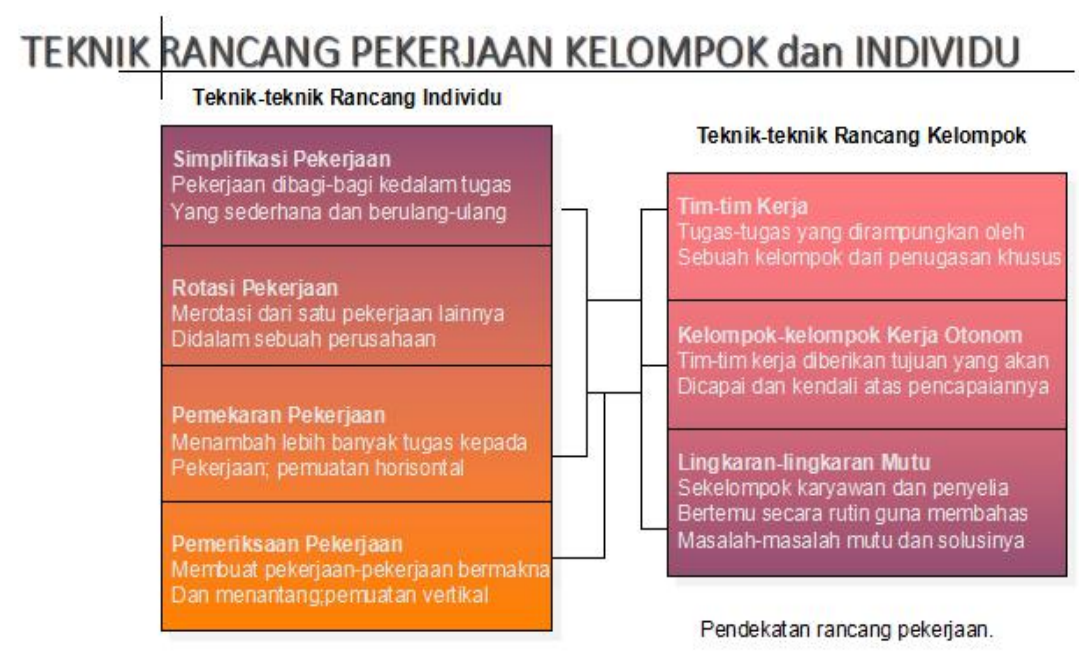

Gambar 4.4 Teknik rancang pekerjaan

5. Aplikasi analisis pekerjaan

\section{Aplikasi Analisis Pekerjaan}

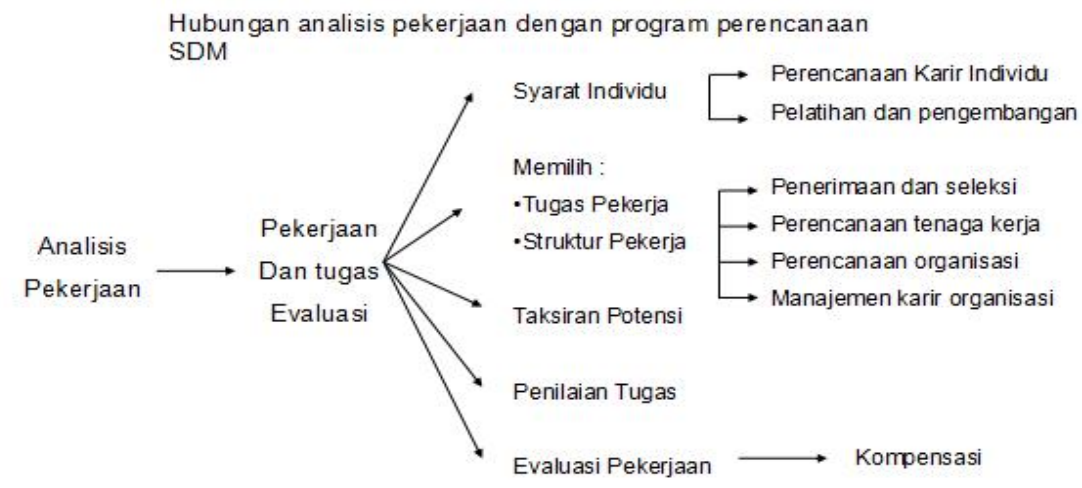

Gambar 4.5 Aplikasi analisis pekerjaan

6. Penggunaan analisis pekerjaan

Analisis pekerjaan bermanfaat untuk mengumpulkan, mengevaluasi, dan mengorganisasi informasi pekerjaan secara menyeluruh. Informasi analisis pekerjaan dapat dipergunakan untuk;

a. Menetapkan dasar pemberian kompensasi

b. Mengevaluasi faktor-faktor lingkungan yang mempengaruhi pekerjaan 
c. Menghilangkan persyaratan kerja yang menyebabkan diskriminasi pekerjaan individual

d. Merencanakan kebutuhan pengadaan sumber daya manusia untuk waktu yang akan datang

e. Memadukan lamaran-lamaran dengan kualifikasi yang ada

f. Meramalkan dan menentukan kebutuhan bagi karyawan baru dan lama, serta mengembangkan karyawan yang potensial

g. Menetapkan standar prestasi kerja yang realistis

h. Menetapkan karyawan sesuai dengan kemampuan dan keterampilannya

i. Membantu revisi struktur organisasi dan memperbaiki aliran kerja Orientasi karyawan

7. Hasil analisis pekerjaan

Berdasarkan data yang dikumpulkan akan didapat dua output besar yaitu deskripsi/ uraian pekerjaan dan spesifikasi pekerjaan. Dari hasil uraian pekerjaan kemudian dapat dibangun formulir penilaian prestasi kinerja dan sistem klasifikasi pekerjaan. Sistem klasifikasi ini kemudian secara mantap digunakan untuk mengevaluasi dan sasaran kompensasi. Berdasarkan spesifikasi pekerjaan, maka rekrutmen dan seleksi dapat direncanakan serta dapat pula digunakan untuk merancang pelatihan pengembangan pegawai.

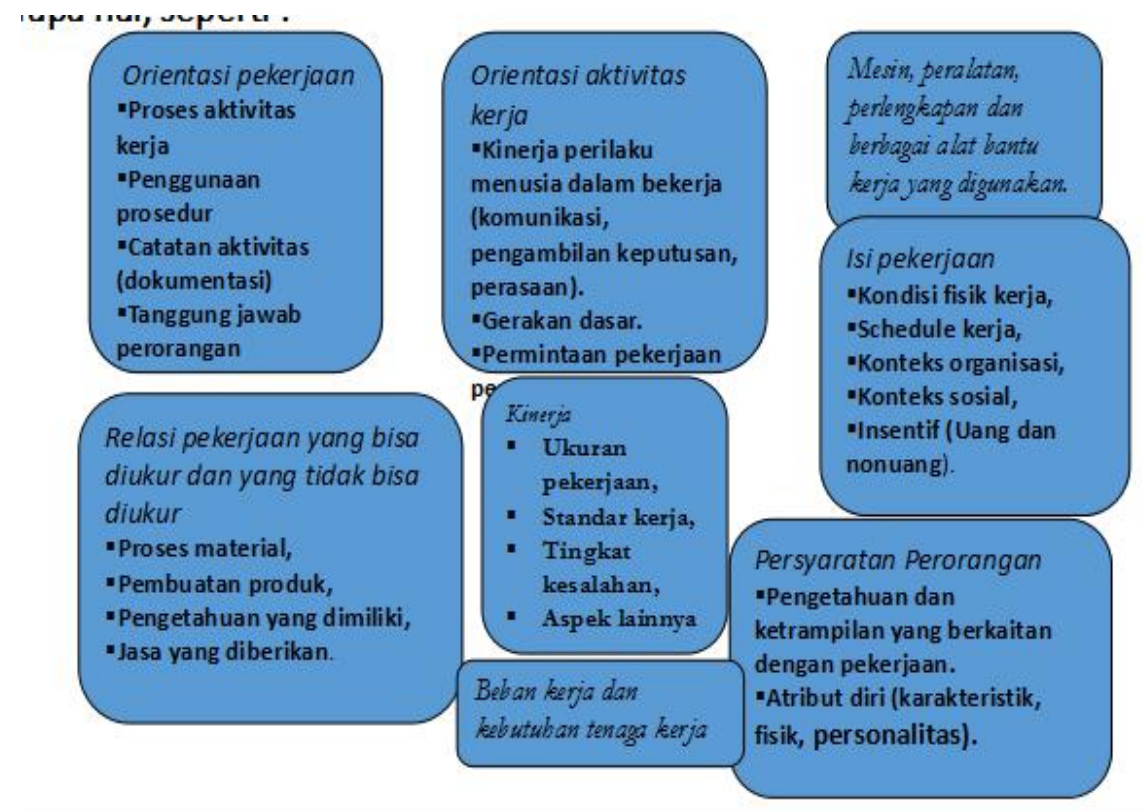

Gambar 4.6 Sejumlah informasi yang akan didapat dari hasil analisis pekerjaan 


\section{Model Karakteristik Pekerjaan dari Motivasi Kerja}

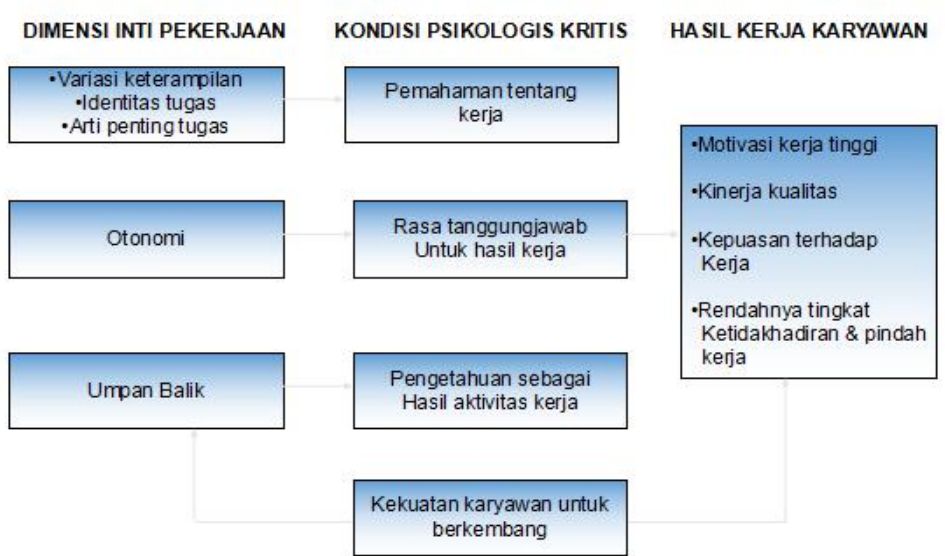

Gambar 4.7 Model Karakteristik Pekerjaan dari Motivasi Kerja 


\section{MATERI V}

\section{Proses Rekrutmen}

\section{A. Sub Materi 1: Rekrutmen}

Proses untuk mendapatkan sejumlah SDM yang berkualitas untuk menduduki suatu jabatan atau pekerjaan dalam suatu perusahaan.

Serangkaian kegiatan yang dimulai ketika sebuah perusahaan atau organisasi memerlukan tenaga kerja dan membuka lowongan sampai mendapatkan calon yang diinginkan sesuai dengan jabatan yang yang ada.

1. Hal yang penting dalam rekrutmen adalah :

a. Bagaimana mengidentifikasi strategi rekrutmen berdasarkan informasi dari analisis pekerjaan dan perencanaan SDM

b. Bagaimana aturan dan cara rekrutmen pada sebuah perusahaan untuk mengorganisasikan tujuan-tujuan tindakan yg telah ditetapkan

c. Membahas mengenai proses rekrutmen sebagai dasar penempatan

d. Kaitan metode rekrutmen dengan jenis pekerjaan atau tuga yang berbeda

e. Bagaiamana aturan penempatan dalam perusahaan, kantor tenaga kerja dan organisasi lain pencari tenaga kerja

f. Deskripsi aturan tentang aplikasi dalam rekrutmen dan seleksi

2. Alasan adanya perekrutan, Gomes $(2003 ; 105)$
a. Berdirinya organisasi baru
b. Adanya perluasan (ekspansi) kegiatan organisasi
c. Terciptanya pekerjaan-pekerjaan dan kegiatan-kegiatan baru
d. Adanya pekerjaan yang pindah ke organisasi lain
e. Adanya pekerja yang berhenti, baik dengan hormat maupun tidak dengan hormat sebagai tindakan preventif
f. Adanya pekerja yang berhenti karena memasuki usia pensiun, dan
g. Adanya pekerja yang meninggal dunia.

3. Perekrutan 
a. Hakekat rekrutmen adalah suatu proses menentukan dan menarik pelamar yang mampu untuk bekerja dalam suatu perusahaan.

b. Proses rekrutmen dimulainya para pelamar dicari dan berakhir ketika lamaran mereka diserahkandikumpulkan

c. Hasil rekrutmen : sekumpulan pelamar calon karyawan baru untuk diseleksi dan dipilih.

4. Tujuan perekrutan

Menerima pelamar sebanyak-banyaknya sesuai dengan kualifikasi kebutuhan perusahaan dari berbagai sumber, sehingga memeungkinkan akan terjaring calon karyawan dengan kualitas tertinggi dari yang terbaik.

5. Isu Stratejik Dalam Rekrutmen (Schuler and Jackson, 2006)

a. Proses rekrutmen harus konsisten dengan strategi, visi, dan nilai-nilai organisasi.

b. Proses rekrutmen harus bisa dilaksanakan secara efisien dan efektif.

c. Proses rekrutmen harus dibarengi dengan kemampuan organisasi dalam mempertahankan para karyawan terbaik.

6. Strategi Rekrutmen (Mathis and Jackson, 2003)

a. Human Resource Planning

1) How many employees needed

2) When will employees be needed

3) What spesific KSAs needed

4) Diversity goals to be met

b. Organizational Responsibilities

1) HR staff and operating managers

2) Recruiting presence and image

3) Training of recruiters

c. Strategic Recruiting Decisions

1) Organizational-based vs outsourcing

2) Reguler vs flexible staffing

3) EEO/diversity considerations

4) Recruiting source choices 


\section{d. Recruiting Methodes}

1) Internal methods

2) Internet/Web-based

3) External methods

7. Sumber rekrutmen

a. Sumber Internal (Rencana suksesi; Job Posting; Perbantuan pekerja; Keluarga pekerja; Promosi \& pemindahan)

Keuntungan:

Tidak terlalu mahal; Dapat memelihara loyalitas dan mendorong usaha yang jelas; Sudah terbiasa dengan suasana perusahaan sendiri

Kelemahan

Pembatasan terhadap bakat-bakat; Mengurangi peluang; Dapat meningkatkan perasaan puas diri

b. Sumber eksternal (Pelamar / Walk-ins and write-ins, Lembaga Pendidikan, Rekomendasi Karyawan, Agen Tenaga Kerja, Organisasi Profesi, Iklan, Open house)

8. Hal yg sering timbul dalam perekrutan
a. Rencana SDM dan strategi
b. Kesempatan kerja yang sama
c. Kebisaan rekruter yg mengarah pada keputusan membatasi konsumi waktu
d. Persyaratan pekerja
e. Harga pelamar dalam proses rekrutmen
f. Kebijakan perusahaan untuk memperoleh manfaat informasi dan ekonomi 


\section{MATERI VI}

\section{Pengembangan Sumber Daya Manusia}

\section{A. Sub Materi 1: Deskripsi Pengembangan SDM}

"Upaya manajemen yang terencana dan dilakukan secara berkesinambungan untuk meningkatkan kompetensi pekerja dan untuk kerja organisasi melalui program pelatihan, pendidikan dan pengembangan"

(Mondy and Noe, 1990)

Pengembangan Sumber Daya Manusia dirancang untuk membantu individu, kelompok, dan organisasi secara keseluruhan, agar menjadi lebih efektif. Program ini diperlukan karena manusia, pekerjaan dan organisasi selalu berubah.

\section{Perubahan SDM terjadi karena}

a. Dinamika internal organisasi maupun dinamika faktor-faktor eksternal

b. Perkembangan teknologi misalnya mempunyai implikasi terhadap syarat-syarat atau tuntutan pekerjaan

c. Kesenjangan antara kemampuan pekerja dan tuntutan pekerjaan yang selalu berkembang, maka diperlukan adanya peningkatan atau penyesuaian pengetahuan dan keterampilan serta sikap pekerja

d. Dengan kata lain diperlukan sikap profesionalisme

2. Jenis-jenis pengembangan SDM

a. Pelatihan (Trainning)

Meliputi aktivitas-aktivitas yang berfungsi meningkatkan unjuk kerja seseorang dalam pekerjaan yang sedang dijalani atau yang terkait dengan pekerjaannya.

b. Pendidikan (Education)

Mencakup kegiatan-kegiatan yang diselenggarakan untuk meningkatkan kompetensi menyeluruh seseorang (Overall Competence) dalam arah tertentu dan berada di luar lingkup pekerjaan yang ditanganinya saat ini. 


\section{c. Pengembangan (Development)}

Meliputi pemberian kesempatan belajar yang betujuan untuk mengembangkan individu, tetapi tidak dibatasi pada pekerjaan tertentu pada saat ini atau pada masa yang akan datang

\section{Tujuan pengembangan SDM}

Sasaran langsung dari program pelatihan dan pengembangan dalam organisasi adalah untuk:

a. Meningkatkan kesadaran diri/individu

b. Meningkatkan keterampilan dalam satu bidang atau lebih

c. Meningkatkan motivasi individu untuk melaksanakan tugas atau pekerjaannya secara memuaskan

Wexley, 1991

Dengan kata lain, melalui peningkatan kemampuan dan unjuk kerja individu dan kelompok, program pelatihan pada gilirannya diharapkan dapat meningkatkan unjuk kerja organisasi.

\section{Faktor-faktor yang mempengaruhi SDM}

Menurut Mondy dan Noe (1987) ada tujuh faktor yang mempengaruhi pengembangan SDM:

a. Dukungan manajemen puncak

b. Komitmen para spesialis dan generalis dalam pengelolaan SDM

c. Perkembangan teknologi

d. Kompleksitas organisasi

e. Pengetahuan tentang ilmu-ilmu perilaku

f. Prinsip-prinsip belajar

g. Unjuk kerja fungsi-fungsi manajemen SDM lainnya

\section{Proses pengembangan SDM}

Pengembangan Sumber Daya Manusia dimulai dengan

a. Penentuan kebutuhan pengembangan atau suatu penilaian kebutuhan yang komprehensif

b. Penetapan tujuan yang bersifat umum dan spesifik 

c. Pemilihan metoda
d. Pemilihan media
e. Implementasi program
f. Evaluasi program

\section{Analisis kebutuhan SDM}

Untuk menentukan secara tepat kebutuhan pengembangan SDM diperlukan 3 jenis analisis:
a. Analisis organisasi
b. Analisis tugas
c. Analisis orang

Ketiga analisis ini akan menjawab tiga pertanyaan:

1. Pada bagian mana dalam organisasi diperlukan program pengembangan?

2. Apa yang harus dipelajari oleh peserta agar dapat melaksanakan pekerjaan secara efektif?

3. Siapa yang perlu dilatih/dididik dan latihan/pendidikan apa yang perlu diberikan kepada mereka?

\section{Analisis Organisasi}

Analisis organisasi mencakup pengkajian terhadap lingkungan eksternal tempat organisasi beroperasi, tujuan organisasi, sumber daya manusia dan iklim organisasi. Melalui analisis ini dapat ditentukan dibagian mana kegiatan pelatihan dan pengembangan harus diselenggarakan (apakah dibutuhkan?) dan layak diselenggarakan (apakah berhasil?)

Jika jawaban terhadap di mana dan mengapa program pengembangan sudah ditemukan, maka selanjutnya perlu ditentukan rancangan atau isi program itu sendiri. Ini dilakukan melalui analisis terhadap tugas.

Analisis tugas dilakukan dengan cara:

a. Mengidentifikasi tugas-tugas dalam jabatan yang akan dirancang program pelatihannya

b. Mengidentifikasikan pengetahuan, keterampilan, dan sikap yang diperlukan untuk melakukan tugas-tugas tersebut dengan sebaik-baiknya 
Analisis lain yang dilakukan dalam identifikasi kebutuhan adalah analsis terhadap orang (person analysis) yang berfokus pada pekerja secara individual

Analisis ini akan menjawab pertanyaan:

a. Siapa yang memerlukan pelatihan dan apa jenis pelatihannya?

b. Siapa yang perlu dilatih dapat diketahui antara lain dengan melakukan penilaian unjuk kerja

Jika prestasi seseorang di bawah standar, diperlukan analisis lanjutan untuk mengidentifikasikan pengetahuan dan keterampilan spesifik yang dibutuhkannya untuk melakukan tugas-tugas secara baik.

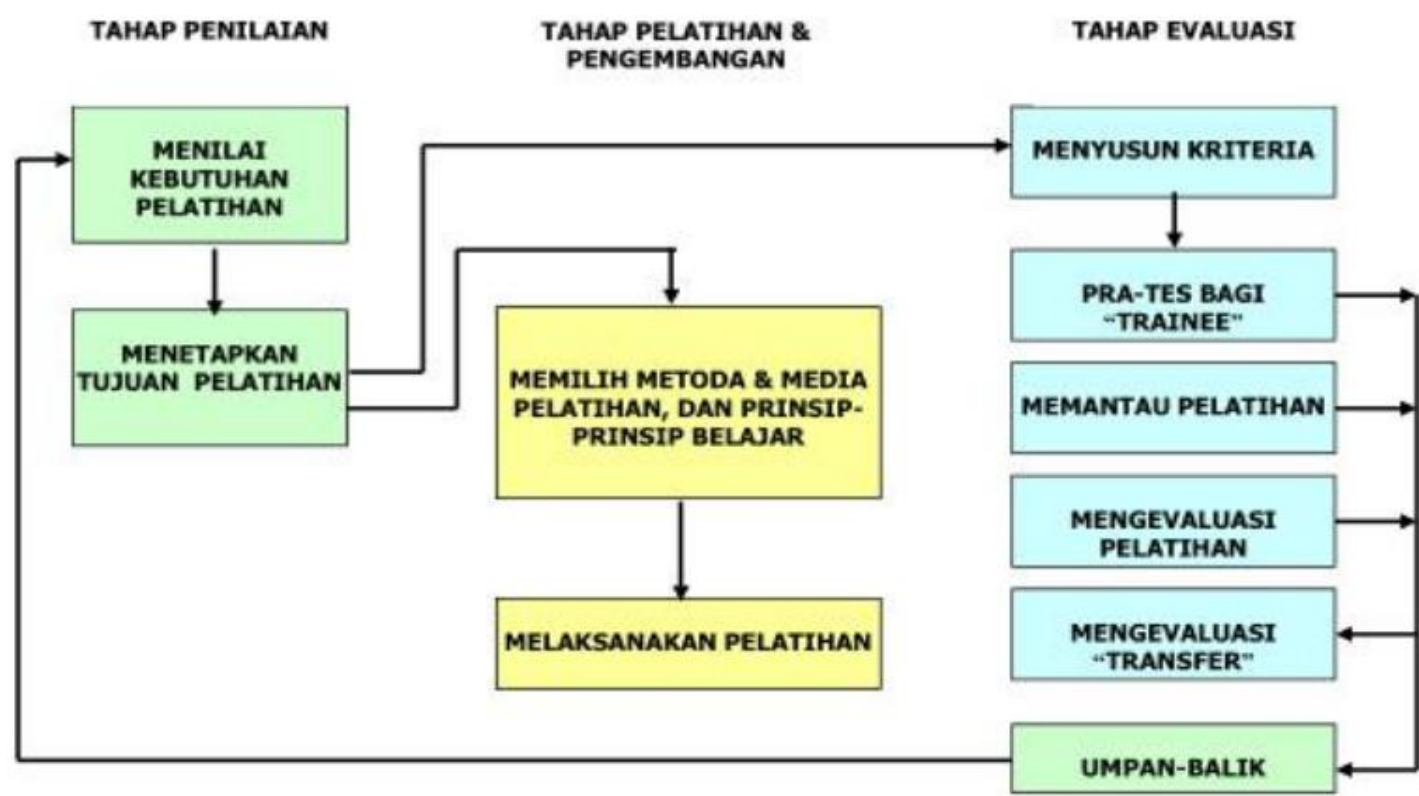

Sumber: Adaptasi dari Cascio. Managing Humna Resources: Productivity, Quality of Work Life, Profits. $\odot 1992 . \mathrm{h} .236$.

Gambar 6.1 Model umum pelatihan dan pengembangan

8. Media pelatihan dan pengembangan

Media adalah metoda atau peralatan khusus yang digunakan untuk mengkomunikasikan gagasan-gagasan dan konsep-konsep didalam program pelatihan dan pengembangan. Media yang lazim digunakan dalam pelatihan dan pengembangan adalah Videotape, film, closed-circuit television, slide projector, overhead and opaque projector, flip chart and chalkboards. 
9. Evaluasi pelatihan dan pengembangan

Pelatihan harus di evaluasi dengan mendokumentasikan atau mencatat secara sistematis hasil-hasil pelatihan. Bagaimana perilaku peserta sesudah mereka kembali bekerja dan relevan tidaknya perilaku peserta dengan tujuan organisasi. Untuk mengetahui manfaat atau nilai pelatihan, kita harus menjawab empat pertanyaan berikut:

a. Apakah terjasi perubahan sesudah pelatihan?

b. Apakah perubahan itu terjadi karena program pelatihan?

c. Apakah perubahan itu mempunyai korelasi positif dengan pencapaian tujuan-tujuan organisasi?

d. Apakah perubahan yang sama akan dialami pula oleh peserta baru yang mendapatprogram pelatihan yang sama?

Menurut Cascio (1993), dalam mengevaluasi program pelatihan, kita mengukur perubahan yang terjadi dalam empat kategori:

a. Reaksi, Bagaimana perasaan peserta terhadap program pelatihan?

b. Belajar, Sampai pada tingkat apa peserta belajar dari apa yang diajarkan?

c. Perilaku, Perubahan perilaku apa (dalam konteks pekerjaan) yang terjadi sebagai hasil dari kehadiran dalam program pelatihan?

d. Hasil, Sejauh mana diperoleh perubahan perilaku yang terkait dengan biaya (misalnya, peningkatan produktivitas atau kualitas, penurunan turn over atau kecelakaan kerja) sebagai hasil dari program pelatihan? 


\section{MATERI VII}

\section{Konseling dan Karier}

\section{A. Sub Materi 1: Konsep Bimbingan dan Karier}

Secara etimologi kata bimbingan merupakan terjemahan dari kata "Guidance" berasal dari kata kerja "To Guide" yang mempunyai arti "menunjukkan, membimbing, menuntun ataupun membantu". Sesuai dengan istilahnya, maka secara umum bimbingan dapat diartikan sebagai suatu bantuan atau tuntunan.

Definisi bimbingan berarti pemberian bantuan kepada seseorang atau kepada sekelompok orang di dalam membuat pilihan-pilihan secara bijaksana dan dalam mengadakan penyesuaian diri terhadap tuntunantuntunan hidup.

Istilah konseling dapat dipahami sebagai bagian dari bimbingan baik sebagai pelayanan maupun sebagai teknik. Konseling merupakan inti kegiatan bimbingan secara keseluruhan dan lebih berkenaan dengan masalah individu secara pribadi yang dilakukan secara individual antara klien dan konselor.

1. Tujuan adanya bimbingan konseling

a. Mengembangkan seluruh potensi dan kekuatan yang dimilikinya seoptimal mungkin.

b. Mampu memilih memutuskan, dan merencanakan hidupnya secara bijaksana baik dalam bidang pendidikan pekerjaan dan sosial pribadi.

c. Mampu mengatasi hambatan serta kesulitan yang dihadapi dalam penyesuaian dengan lingkungan pendidikan, masyarakat, ataupun lingkungan kerja

d. Memahami dan mengarahkan diri dalam bersikap dan bertindak sesuai keadaan lingkungannya.

e. Memelihara dan mencapai kesehatan mental yang positif, menyelesaikan segala sesuatu dengan bijaksana

2. Fungsi bimbingan dan konseling

a. Fungsi Pemahaman 

b. Fungsi Penyaluran
c. Fungsi Adaptasi
d. Fungsi Penyesuaian
e. Fungsi Pemeliharaan dan Pengembangan

3. Asas-asas bimbingan konseling
a. Asas kerahasiaan
b. Asas alih tangan kasus (yang menangani harus yang ahli, jika tidak bisa dialihkan kepada yang lebih ahli)
c. Asas kesukarelaan
d. Asas keterbukaan
e. Asas keterpaduan
f. Asas keahlian khusus (penyelenggaraan atas kaidah profesionalisme)

4. Metode dan teknik bimbingan konseling

a. Metode

1) Metode bimbingan kelompok

2) Metode bimbingan individual

a) Konseling direktif

b) Konseling non direktif

b. Teknik

1) Teknik Rapport ( suatu kondisi saling memahami dan mengenal tujuan bersama)

2) Teknik Structuring (Structuring memberikan kerangka kerja atau orientasi terapi kepada klien)

3) Teknik Eksplorasi (keterampilan konselor untuk menggali perasaan, pengalaman, dan pikiran klien)

4) Teknik Mengarahkan/ Directing (untuk mengajak klien berpartisipasi secara penuh di dalam proses konseling, perlu ada ajakan dan arahan dari konselor)

5) Teknik Mengakhiri (untuk mengakhiri sesi konseling dapat dilakukan konselor dengan cara mengatakan bahwa waktu sudah habis, merangkum isi pembicaraan, menunjukkan kepada pertemuan yang akan datang, mengajak klien berdiri dengan isyarat gerak tangan, menunjukkan 
catatan-catatan singkat hasil pembicaraan konseling, memberikan tugas-tugas tertentu kepada klien yang relevan dengan pokok pembicaraan apabila diperlukan.

\section{B. Sub Materi 2: Perencanaan dan Pengembangan Karier}

\section{Pengertian}

Karier terdiri dari semua pekerjaan yang ada selama seseorang bekerja, atau dapat pula dikatakan bahwa Karier adalah semua jabatan/pekerjaan yang dimiliki/dipegang selama kehidupan kerja seseorang. Untuk orang-orang tertentu jabatan-jabatan ini merupakan tahapan dari suatu perencanaan yang cermat, sedangkan bagi yang lain, karier merupakan bentuk keberuntungan. Meskipun seseorang telah menyusun perencanaan suatu karier tidak menjamin kariernya menjadi berhasil.

Untuk beberapa orang bekerja adalah bagian dari suatu rencana, sedangkan untuk beberapa orang lainnya karier hanyalah merupakan sesuatu keberuntungan saja. Ada beberapa peren penting dalam menunjang kesuksesan seseorang yaitu Kinerja yang unggul, Pengalaman, pendidikan, keahlian dan keberuntungan. Kesuksesan seseorang diindentifikasikan sebagai tujuan karier, rencana, dan kemudian tidakan. Sedangkan keberuntungan hanya terjadi ketika ada titik temu antara kesempatan dan persiapan. Perencanaan karier adalah suatu perencanaan tentang kemungkinan seorang karyawan suatu organisasi atau perusahaan sebagai individu meniti proses kenaikan pangkat atau jabatan sesuai persyaratan dan kemampuannya.

Pengembangan karier terdiri atas peningkatan pribadi yang dijalani seseorang untuk mencapai rencana kariernya dan hal ini menjadi tanggung jawab karyawan tersebut. Manajer dan departeman SDM hanya membantu di dalam perencanaan karier serta memberikan jalan menuju karier tersebut. Beberapa pertanyaan kunci yang kerap diajukan kebanyakan orang, terutama tentang lingkungan pekerjaan yang mengharapkan tanggung jawab individu yang tinggi, apapun upayanya dalam mengelola karier. Sejumlah orang berpendapat, siapa yang mampu memprediksi kemana karier menuju pada 10,20, atau 30 tahun ke depan?

Meskipun manajer dan departeman SDM bisa mempafasilitasi proses perencanaan karier dan membantu menjawab beberapa pertanyan tentang 
jenjang karier yang tepat, pada akhirnya tanggung jawab kemajuan karier karayawan akan terpulang pada karyawan itu sendiri. Kendati demikian, lebih banyak perusahaan yang terus maju dan menganggap bantuan perencanaan karier sebagai cara untuk membantu memastikan pemasokan yang memadai bakat internal.

2. Konsep-konsep dasar perencanaan karier

a. Karier . Merupakan seluruh posisi kerja yang dijabat selama silkus kehidupan pekerja seseorang

b. Jenjang karier. Merupakan model posisi pekerjaan berurutan yang membentuk karier seseorang

c. Tujuan karier. Merupakan posisi mendatang yang diupayakan pencapaiannya oleh seseorang sebagai bagian kariernya

d. Perencanaan karier. Merupakan proses dimana kita menyeleksi tujuan karier dan jenjang karier menuju tujuantujuan tersebut

e. Pengembangan karier. Terdiri dari peningkatan pribadi yang dilakukan oleh seseorang dalam mencapai rencana karier pribadinya.

Dengan demikian karier adalah seluruh pekerjaan yang dimiliki atau dilakukan oleh individu selama masa hidupnya. Karier merupakan pola dari pekerjaan dan sangat berhubungan dengan pengalaman (posisi, wewenang, kepuasan, dan interpretasi subjektif atas pekerjaan) dan aktivitas selama masa kerja individu.

Definisi ini menekankan bahwa karier tidak berhubungan dengan kesuksesan atau kegagalan, namun lebih kepada sikap dan tingkah laku, dan kontinuitas individu dalam aktivitas yang berkaitan dengan pekerjaannya. Tujuan karier adalah posisi dimasa mendatang yang ingin dicapai oleh individu dalam pekerjaannya.

3. Tujuan dan manfaat perencanaan dan pengembangan karier

Sepanjang sejarah peranan depertemen SDM sangat terbatas, sejalan dengan terbatasnya SDMyang dimiliki serta masih adanya anggapan bahwa perencanaan karier dipandang sebagai persoalan individu. Padahal perencanaan karier merupakan Cara untuk memenuhi kebutuhan internal karyawan. 
Dengan perencanaan karier para karyawan dapat menetapkan tujuan kariernya, di mana hal ini akan mendorongnya untuk meraih jenjang pendidikan lebih lanjut serta pelatihan dan kegitan pengembangan lainnya sehingga akan menambah jumlah kualifikasi pelamar internal dan dengan demikian formasi pekerjaan dapat dipenuhi secara internal, tidakperlu merekrut pelamar dari luar.

\section{a. Manfaat pengembangan karier}

Pengembangan karier pada dasarnya memiliki manfaat yang hampir sama dengan apa yang dikemukakan di atas,namun manfaat pengembanganini ada kekhususan karena sudah menyangkut kegiatan pendidikan dan latihan Manfaat tersebut adalah sebagai berikut:

1) Meningkatkan kemampuan karyawan

2) Meningkatnya suplay karyawa yang berkemampuan

b. Tujuan dan tanggung jawab pengembangan karier

Pengembangan karier sebagai kegiatan manajemen SDM pada dasarnya bertujuan untuk memperbaiki dan meningkatkan efektivitas pelaksanaan pekerjaan oleh pekerjaan oleh para pekerja, agar semakin mampu memberikan kontribusi terbaik dalam mewujudkan tujuan bisnis organisasi.

Dalam hal tanggung jawab, pengembangan karier dibedakan menjadi 2 pendekatan yaitu:

1)Dengan pendekatan tradisional

2)Dengan pendekatan baru

4. Ada 5 hal yang menjadi keinginan karyawan

a. Persamaan karier (career equity)

b. Masalah pengawasan (supervisory concern)

c. Kesadaran akan adanya kesempatan (awarenes of opportunity)

d. Minat karyawan (employent interest)

e. Kepuasan karier (career satisfaction)

\section{Perencanaan karier}

a. Kebutuhan dan kesempatan karyawan dan perusahaan dapat disesuaikan dengan berbagai cara. 
b. Pendekatan yang paling sering digunakan adalah konseling karier oleh karyawan dengan penyelia. Sedangkan pendekatan formal jarang digunakan, seperti workshop, seminar, dan pusat-pusat pengembangan diri.

c. Konseling karier yang dilakukan oleh penyelia umumnya termasuk pula evaluasi kinerja.

6. Tujuan dan manfaat perencanaan karier

a. Meluruskan strategi dan syarat-syarat karyawan intern (aligns strategy and internal staffing)

b. Mengembangkan karyawan yang dapat dipromosikan (develops promotable employees)

c. Memudahkan penempetan keluar negeri (facilitates internal plecement)

d. Membantu di dalam keaneka ragaman tenaga kerja (assists with workforce deversity)

e. Mengurang pergantian (lower turnover)

f. Menyaring potensi karyawan (taps employee potential)

g. Meneruskan pertumbuhan pribadi (furthers personal growth)

h. Mengurani penimbunan (raduce hoarding)

i. Memuaskan kebutuhan karyawan (satisfies employee needs)

j. Membantu perencanaan tindakan secara afirmatif (assists affirmative action plans)

7. Dukungan perusahaan

Untuk dapat terwujudnya manfaat perencanaan karier perusahaan harus mendukung melalui:

a. Pendidikan karier

b. Informasi tentang Perencanaan karier

c. Konseling karier

d. Bimbingan karier:

1) Penilaian karier diri sendiri oleh karyawan

2) Penilaian terhadap lingkungan 


\section{Pola karier}

a. Hasil dari perencanaan karier adalah penempatan SDM pada bidang tugas yang merupakan bagian awal dari rangkaian suatu pekerjaan.

b. Dari perspektif perusahaan, pola karier merupakan perencanaan yang penting di bidang SDM.

c. Pola karier didefinisikan sebagai bagian dari pekerjaan yang membentuk karier individu.

9. Pengembangan karier

a. Pengembangan karier Individu

1) Prestasi Kerja (job Performance)

2) Eksposur (exposure)

3) Jaringan Kerja (net working)

4) Pengunduran Diri (resignations)

5) Kesetiaan terhadap organisasi (organizational loyality)

6) Pembimbing dan sponsor (mentors sponsors)

7) Bawahan yang mempunyai peranan kunci (key subordinatess)

8) Peluang untuk tumbuh (growth opportunies)

9) Pengalaman Internasional (international experience)

$b$. Pengembangan Karier yang didukung oleh Departemen SDM

c. Peran Pimpinan Dalam Pengembangan Karier

d. Peran Umpan Balik terhadap Pengembangan Karier

1) Untuk menjamin bahwa karyawan yang gagal menduduki suatu posisi dalam rangka pengembangan kariernya masih tetap berharga dan akan dipertimbangkan lagi untuk promosi diwaktu mendatang bila mereka memenuhi syarat

2) Untuk menjelakan kepada karyawan yang gagal kenapa mereka tidak terpilih

3) Untuk mengidentifikasi apa tinakan-tindakan pengembangan karier spesifik yang harus mereka laksanakan 
10. Pilihan pengembangan karier

Pengembangan karir itu sendiri mempunyai arah atau jalur-jalur serta pilihan yang akan memberikan kepada setiap karyawan untuk mengembangkan karirnya sepanjang arah itu mencerminkan tujuan dan kemapuannya. Pilihan arah yang ingin dikembangkan merupakan kesempatan yang baik bagi karyawan itu sendiri di manapun dan kapanpun. Pilihan arah atau jalur pengembangan karier meliputi.

a. Enrichment

b. Lateral

c. Vertical

d. Relocation

e. Exploration

f. Realignment

Yaitu pergerakan kearah bawah yang mungkin dapat merfleksikan sesuatu peralihan atau pertukaran prioritaspekerjaan bagi karyawan untuk mengurangi resiko, tanggung jawab, dan stress, menempatkan posisi karyawan tersebut kearah yang lebih tepat yang sekaligus sebagai kesempatan atau peluang yang baru.

11. Tahap-tahap pengembangan karier individu

\begin{tabular}{l|l|l|l|l} 
Kebututan & Keamanan, & Pencapaian, Harga & Harga Diri, & Aktualisasi Diri \\
Utama & Jaminan Psikologi & Diri, Kebebasan & Aktualisasi Diri & \\
\cline { 2 - 4 }
\end{tabular}

Usia

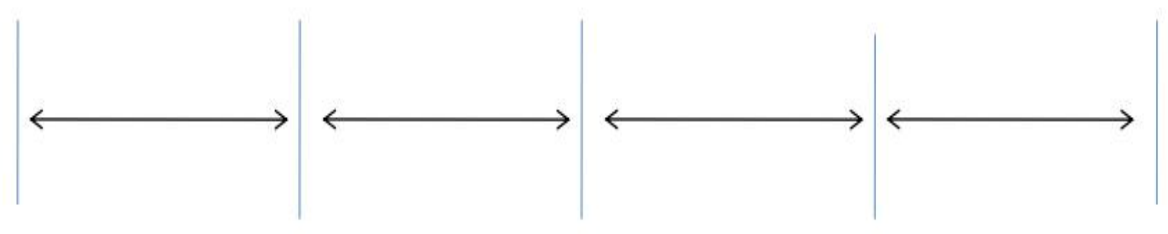

Tahap

Fase Awal

Karier
Fase Lanjutan

Promosi

\section{Fase Mempertahankan Fase Pensiun \\ Mempertahankan posisi \\ Berfikir Strategis}

\section{Tahap-Tahap Karier}

Gambar 7.1 Tahap pengembangan karier individu 
Penjelasan gambar 7.1

a. Fase Awal pembentukan, menekankan pada perhatian untuk memperoleh jaminan terpenuhinya kebutuhan dalam tahun-tahun awal pekerjaan

b. Fase Lanjutan, dimana pertimbangan jaminan keamanan sudah mulai berkurang, namun lebih menitik beratkan pada pencapaian, harga diri dan kebebasan

c. Fase Mempertahankan, pada fase ini individu mempertahankan pencapaian keuntungan atau manfaat yang telah diraihnya sebagai hasil pekerjaan dimasa lalu

d. Fase Pensiun, pada fase ini Individu talah menyelesaikan satu karier, dan ia akan berpindah ke karier yang lain.

12. Program pengembangan karier

a. . Pengembangan Karier Terintegrasi dengan Perencanaan SDM.

Hubungan antara pengembangan karier dan perencanaan SDM adalah cukup jelas. Pengembangan karier menyediakan bakat dan kemampuan, sementara Perencanaan SDM memproyeksikan kebutuhan perusahaan terhadap bakat dan kemampuan. Walaupun perusahaan telah membuat suatu program pengembangan karier dan perencanaan SDM, namun perusahaan menemui kesulitan untuk mengintegrasikan keduanya.

Alasan pertama, kesulitan tersebut karna kedua program tersebut dikerjakan oleh ahli-ahli yang berbeda.Pengembangan karier dikerjakan oleh psikolog, sementara perencanaan SDM dikerjakan oleh ahli-ahli ekonomi dan sistem analisis. Ahli-ahli yang mempunyai disiplin ilmu yang berbeda ini biasanya memiliki kesulitan dalam komunikasi karena latar belakang pendidikan dan pengalaman mereka menjadikan suatu karier atau halangan untuk berkomunikasi secara efektif.

Alasan kedus, berkaitan dengan struktur organisasi perusahaan. Pengembangan karier umumnya merupakan fungsi dari departeman SDM, sementara perencanaan SDM merupakan fungsi dari perencanaan staf. Kedua aktivitas tersebut dijalankan oleh unit organisasi/departemen yang berbeda. 


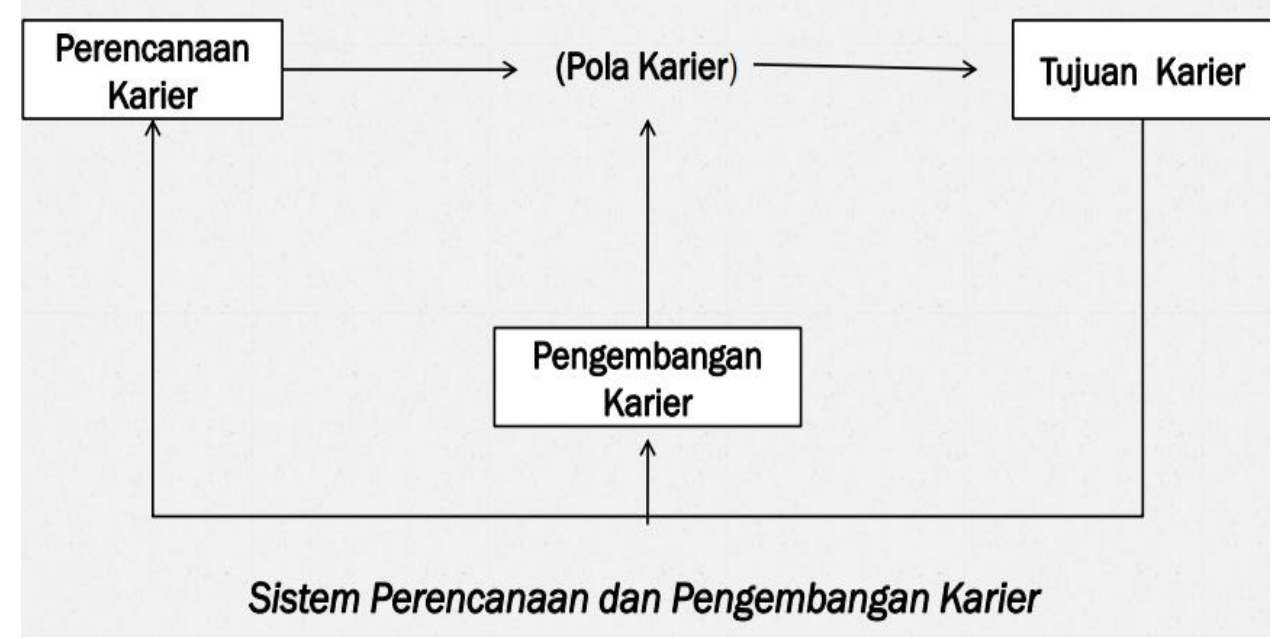

Gambar 7.2 Hubungan perencanaan dan pengembangan karier

Tanpa umpan balik, sangat sulit bagi karyawan untuk mengetahui prestasi/kekurangan atas pekerjaan yang telah dilakukannya. Umpan balik memilki tiga tujuan utama, yaitu:

a. Untuk meyakinkan karyawan bahwa mereka masih berharga dan akan dipertimbangkan untuk promosi di masa yang akan datang apabila mereka memenuhi kualifikasi

b. Untuk menjelaskan mengapa karyawan tidak terpilih untuk menduduki jabatan tertentu

c Untuk mengindentifikasi rindakan khusus yang sebaiknya mereka lakukan dalam rangka pengembangan karier

13. Kebutuhan karyawan

Dalam bekerja, di samping untuk memenuhi kebutuhan hidupnya, karyawan juga membutuhkan:

a. Persamaan Perlakuan untuk karier

b. Pengawasan

c. Kesadaran terhadap kesempatan

d. Minat karyawan

e. Kepuasan karier 
14. Pendekatan Diagnotik Untuk Perencanaan Dan Pengembangan Karier Pada pendekatan diagnotik, perencanaan dan pengembangan karier dipengaruhi oleh dua faktor penting, yaitu:

a. Pengaruh lingkungan eksternal, antara lain:

1). Peraturan perudang-undangan dan persyaratan yang dikeluarkan oleh pemerintah

2). Serikat pekerja

3). Kondisi ekonomi

4). Tingkat kompetisi

5). Komposisi angkatan kerja

6). Lokasi organisasi

b. Pengaruh lingkungan internal antara lain:

1). Strategi Perusahaan

2). Tujuan Perusahaan

3). Budaya Perusahaan

4). Sifat Pekerjaan

5). Gaya kepemimpinan dan pengalaman

Karier individu umumnya berjalan melalui tahap-tahap tertentu. Masing-masing tahap mungkin dipengaruhi oleh sikap, motivasi, sifat karyawan, kondisi ekonomi, dan lain-lain

\section{Karier tanpa batas}

Karier tanpa batas memerlukan suatu kompetensi yang berbeda. Kompetensi yang diperlukan untuk karier tanpa batas adalah:

a. Knowledge base tecnical speciality

b. Cross functional and international experience

c. Collaborative leadership

d. Self management skills

e. Personal traits

16. Instrumen Pengukuran Pengembangan Karier

a. Petunjuk pengisian bagi karyawan

1) Dimohon kesediaan Anda untuk membaca dengan cermat butir-butir pertanyaan yang terdapat pada lembaran berikut ini, kemudian pilihlah 
salah satu jawaban yang menurut Anda paling tepat/sesuai dengan yang Anda alami, Anda ketahui, dan Anda yakini dengan memberikan lingkaran pada salah satu jawaban pilihan Anda.

2) Instrumen ini semata-mata untuk tujuan penelitian, sehingga Anda tidak perlu mencantumkan nama ataupun identitas lainnya

3) Apapun jawaban Anda, akan dijamin kerahasiannya

4) Apapun jawaban Anda, akan membantu kami dalam upaya untuk lebih meningkatkan kualitas pengelolaan pelatihan (Diklat)

5) Apa bila Anda ingin mengubah pilihan yang telah Anda tandai, berilah tanda silang $(\mathrm{X})$ pada pilihan lama, dan kemudian berikan lagi lingkaran pada pilihan baru.

17. Penting untuk Departemen SDM

a. Instrumen ini akan lebih bermanfaat bila dalam tabulasinya hanya pada karyawan yang levelnya (jabatan, pangkat, fungsi atau tugas) yang sama

b. Instrumen ini sebaiknya Anda berikan kepada semua karyawan, atau kalau karyawan pada perusahaan Anda di atas 100 sebaiknya dilakukan dengan simple random sampling

c. Ciptakan suasana tenang, bersahabat dan jauhkan responden dari tekanan attaupun ancaman ketika mereka menjawab instrumen penelitian ini

d. Masing-masing butir jawaban diberi bobot nilai : (a) $=5$; (b) $=4$; (c) $=3$; (d) $=2$ dan $(\mathrm{e})=1$.

e. Setelah Instrumen pengukuran ini dijawab oleh responden, lalu ditabulasi dan bila hasil tabulasi menunjukkan rata-rata skor di atas 4, artinya pengembangan karier telah dilaksanakan dengan baik, meskipu masih perlu ada perbaikan.

f. Namun bila rata-rata skor cenderung berada dibawah 3, perlu diteliti lebih lanjut penyebabnya.

g. Kaji secara mendalam dengan melibatkan semua pihak yang terkait dengan pengembangan karier karyawan

h. Sebaiknya setiap periode (setahun) instrumen ini diperbaharui sesuai dengan perkembangan, dengan mengacu dan merujuk pada teoruteori baru, sehingga terhindar dari kepentingan pribadi. 
18. Mendesain program pengembangan karier

Desain program pengembangan karier ini akan membantu para manajer dalam membuat keputusan yang kreatif mengenai pengembangan karier para pekerja.Untuk itu perlu dibedakan atas tiga fase dalam mendesain program pengembangan karier yang terdiri dari:

a. .Fase perencanaan

b. .Fase pengarahan

1) .Pengaranan dengan menyelenggarakan konseling karier.

2) Perbedaan dengan menyelenggarakan playanan informasiyang mencakup kegiatan sebagai berikut:

a) Sistem pemberitaan pekerjaan sasaran terbuka.

b) Menyediakan informasi inventarisasikemapuan pekerja, yang dapat dan boleh diketahui oleh masing-masing pekerja.

c) Informasi tentang alirankarier berupa chart yang menunjukan kemungkinan arah dan kesempatan yang tersedia di dalam organisasi.

d) Selenggarakan pusat sumber pengembangan karier merupakan himpunan bahan-bahan yang berhubungan dengan pekerjaan jabatan, dan lain-lain.

c. Fase pengembangan

Fase ini adalah tenggang waktu yang diperlukan pekerja untuk memenuhi persyaratan yang memungkinkannya melakukan gerak dari suatu posisi ke posisi lain yang menginginkanya. Kgiatan-kegitan yang dapat dilakukan antara lain.

1) .Menyelenggarakan system mentor

2) Pelatihan

3).Rotasi jabatan

4) Program beasisiwa/ ikatan dinas 


\section{MATERI VIII}

\section{Komunikasi, Produktif dan Perencanaan SDM}

\section{A. Sub Materi 1: Pendahuluan}

1. Komunikasi

Masalah produktivitas kerja dalam suatu organisasi merupakan faktor yang penting. Komunikasi memegang peranan penting bagi kehidupan suatu organisasi, baik perusahaan swasta maupun pemerintahan. Komunikasi penting untuk menjalin hubungan kerja sama antara manusia yang terlibat dalam organisasi dan mempunyai pengaruh yang sangat besar dalam proses pencapaian tujuan organisasi.

\section{Komunikasi Organisasi}

Organisasi harus menyadari bahwa salah satu kunci penting tercapainya tujuan tergantung pada kemampuan pegawai dan pimpinan dalam melakukan komunikasi. Komunikasi menjadi titik penting karena segala proses perencanaan dan pengorganisasian tidak akan dapat dijalankan dengan baik tanpa adanya komunikasi yang baik.

Terdapat tujuh konsep kunci dari komunikasi organisasi sebagaimana dikemukakan oleh Muhammad (2002:67), yaitu:
a. Proses
b. Pesan
c. Jaringan
d. Keadaan Saling Tergantung
e. Hubungan
f. Lingkungan
g. Ketidakpastian

\section{Pembagian komunikasi}

Beberapa bentuk komunikasi organisasi menurut Athoillah (2010:219) adalah sebagai berikut:

a. Dari segi lawannya dapat dibedakan menjadi : 
1) Komunikasi satu lawan satu

2) Komunikasi satu lawan banyak

3) Komunikasi banyak lawan atau kelompok lawan satu

4) Komunikasi kelompok lawan kelompok

b. Dari segi arahnya, dapatdibedakan :

1) Komunikasi ke atas

2) Komunikasi kebawah

3) Komunikasi diagonal keatas

4) Komunikasi horizontal

c. Dari segi sifatnya dibagi :

1) Komunikasi Verbal

2) Komunikasi Non Verbal

Menurut Pace \& Faules (2010:497) beberapa indikator komunikasi organisasi adalah sebagai berikut:
a. Kepuasan organisasi
b. Iklim komunikasi
c. Kualitas media
d. Aksebilitas informasi
e. Penyebaran informasi
f. Beban informasi
g. Ketepatan pesan
h. Budaya organisasi

\section{B. Sub Materi 2: Pengawasan Sumber Daya Manusia}

Menurut Martoyo (2007:237) yang dimaksudkan dengan pengawasan sumber daya manusia adalah bagaimana pihak manajemen mengadakan pengamatan atas:

1. Jumlah sumber daya manusia yang ada dalam organisasi.

2. Jumlah sumber daya manusia yang benar- benar dibutuhkan organisasi.

3. Jumlah pasaran sumber daya manusia yang ada dan memungkinkan.

4. Kualitas sumber daya manusia yang dimiliki dan yang ada di pasaran tenaga kerja.

5. Kemampuan individual setiap sumber daya manusia dalam organisasi. 
6. Upaya peningkatan kemampuan sumber daya manusia dalam organisasi.

7. Semangat kerja mereka dan sebagainya.

Komunikasi Kesehatan.

Dibutuhkan Karena:

1. Gerakan untuk melokalisir para penderita penyakit menular ke suatu tempat tertutup yang terpisah dari masyarakat umum agar penyakit tersebut tidak menular

2. Yakni gerakan pendidikan yang bertujuan mengajarkan ilmu pengetahuan tentang kebersihan kepada masyarakat agar supaya lebih peduli terhadap kebersihan lingkungan. Yang hasilnya dapat menjauhkan dari sumber penyakit atau mencegah tubuh terinfeksi atau tertular dari penyakit yang lain

3. Merupakan gerakan yang mendorong setiap individu melakukan pengawasan terhadap kontak antara tubuh ditempat tempat umum.Gerakan ini umumnya dipelopori oleh pemerintah melalui regulasi mengenai perlindungan kesehatan dari waktu ke waktu

4. Gerakan ini memperkenalkan konsep baru dalam bidang kesehatan masyarakat. Misalnya dengan memperluas agenda kerja maupun ke sasaran masyarakat umum. Misalnya politik hijau,kesehatan kota,kesehatan sanitasi dllPerhatian dunia pada komunikasi kesehatanTahun 1978

WHO membuat kesepakatan mengenai pelayanan kesehatan primer ( primary health care ) yang mencakup 8 unsur pokok bidang kesehatan :

1. Penyuluhan kesehatan

2. Gizi

3. Sanitasi dasar dan air bersih

4. KIA (Kesehatan Ibu dan Anak)

5. Imunisasi terhadap penyakit utama

6. Pencegahan dan pengelolaan penyakit endemik

7. Pengobatan penyakit yang umum di jumpai

8. Tersedianya obat esensial

\section{Sub Materi 3: Komunikasi dan Pendidikan Kesehatan}

1. Komunikasi kesehatan 
Merupakan hubungan konseptual antara komunikasi dan kesehatan. Komunikasi kesehatan adalah studi yang mempelajari bagaimana cara menggunakan strategi komunikasi untuk menyebarluaskan informasi kesehatan yang mempengaruhi individu dan komunitas agar mereka dapat membuat keputusan yang tepat dengan pengelolaan kesehatan. Studi yang menekankan peranan teori komunikasi yang dapat di gunakan dalam penelitian dan praktik yang berkaitan dengan promosi kesehatan

\section{Pendidikan kesehatan}

Yakni suatu pendekatan yang menekankan pada usaha mengubah perilaku kesehatan secara luas agar mereka mempunyai kepekaan terhadap masalah kesehatan

3. Tujuan Strategis komunikasi kesehatan

a. Relay information (meneruskan informasi )

b. Enable informed decision making (memberikan informasi akurat untuk pengambilan keputusan)

c. Promote Healthy behaviors ( informasi untuk memperkenalkan perilaku sehat)

d. Promote self care ( memperkenalkan pemeliharaan kesehatan sendiri)

e. Manage demand for health services (memenuhi permintaan layanan kesehatan

4. Manfaat komunikasi kesehatan

a. Dapat memahami interaksi antara kesehatan dengan perilaku individu,

b. Meningkatkan kesadaran kita tentang isu kesehatan,masalah atau solusi.

c. Komunikasi kesehatan masa depan Telehealth: aplikasi teknologi dan telekomunikasi untukmemperkuat spektrum informasiInteractive health communication: interaksi antaraindividu dengan konsumen,pasien dan penyedia layanan kesehatanConsumer health informatics: interaktif komunikasi kesehatan yang di fokuskan pada komsumenTelemedicine: aplikasi telekomunikasi dan teknologi komputer yang secara khusus melayani klinik 


\section{Sub Materi 4: pengawasan sumber daya manusia}

Mempunyai beberapa fungsi yang penting dalam meningkatkan produktivitas karyawan, yaitu:

1. Mencegah terjadinya penyimpangan atau kesalahan

2. Memperbaiki berbagai penyimpangan atau kesalahan yang terjadi

3. Dapat membuat setiap bagian dalam perusahaan selalu dinamis dan terarah untuk mencapai tujuannya

4. Mempertebal rasa tanggung jawab karyawan

Menurut Yuniarsih dan Suwatno (2009:109) mengatakan bahwa langkah langkah dari pengawasan sumber daya manusia adalah sebagai berikut:

1. Menetapkan Standar

2. Menilai dan mengukur hasil yang telah dicapai

3. Membandingkan antara hasil pengukuran dengan standar

4. Melakukan tindak lanjut (follow up) di sesuaikam dengan kondisi riil yang di capai dari hasil penelitian

\section{E. Sub Materi 5: Produktivitas Kerja Karyawan}

Simanjuntak dalam Sutrisno (2009:103) menyatakan bahwa terdapat beberapa faktor yang dapat mempengaruhi produktivitas kerja karyawan, yaitu:

1. Pelatihan

2. Mental dan kemampuan fisik karyawan

3. Hubungan antara atasan dan bawahan

Untuk mengukur produktivitas kerja diperlukan suatu indikator. Menurut Sutrisno (2009:104) beberapa indikator produktivitas kerja adalah sebagai berikut:

1. Kemampuan

2. Meningkatkan hasil yang dicapai

3. Semangat kerja

4. Pengembangan diri

5. Mutu

6. Efisiensi 


\section{F. Sub Materi 6: Pengertian Perencanaan SDM}

Perencanaan SDM merupakan proses perencanaan sistematis untuk memaksimalkan sumber daya manusia sebagai aset utama perusahaan. Tujuan dari perencanaan SDM ini adalah untuk memastikan kesesuaian antara tenaga kerja dan pekerjaan, baik dari segi jumlah maupun kualitas yang dibutuhkan. Proses ini didasari oleh supply dan demand dalam konteks SDM perusahaan.

\section{Manfaat Perencanaan SDM}

a. Membantu HR (Human Resource) mengantisipasi kebutuhan tenaga kerja dengan berbagai kualifikasi di kemudian hari.

b. HR bisa bekerja secara proaktif dalam menemukan kandidat yang sesuai.

c. Sesuai dengan tujuan masing-masing perusahaan, perencanaan SDM memungkinkan HR untuk mengidentifikasi, memilih, dan mengembangkan kompetensi atau tenaga kerja yang dibutuhkan oleh perusahaan.

\section{Proses perencanaan SDM}

Secara garis besar, proses perencanaan SDM dibagi menjadi 4 langkah yang meliputi:

a. Persediaan tenaga kerja saat ini

Langkah paling awal yang bisa dilakukan dalam memulai perencanaan SDM yaitu menilai ketersediaan sumber daya manusia yang ada di perusahaan.. Penilaian ini termasuk studi komprehensif dari berbagai aspek SDM, seperti jumlah, skill, kompetensi, kualifikasi, pengalaman, usia, jabatan, kinerja, kompensasi, dan lain sebagainya.

b. Kebutuhan SDM di masa mendatang

Dalam langkah ini, berbagai variabel HR seperti pengurangan SDM, lowongan yang akan dibuka, promosi jabatan, mutasi karyawan, dan lain sebagainya perlu dimasukkan ke dalam pertimbangan.

c. Perkiraan permintaan SDM

HR bisa mencocokkan tenaga kerja yang ada saat ini dengan perkiraan kebutuhan tenaga kerja di kemudian hari dan membuat demand forecast (perkiraan permintaan). Dalam langkah ini, penting juga untuk mengetahui strategi dan objektif bisnis jangka panjang, agar perkiraan permintaan bisa sesuai untuk memenuhi kebutuhan perusahaan. 
d. Strategi dan implementasi pencarian SDM

Setelah mengetahui kekurangan yang dibutuhkan dari evaluasi supply dan demand SDM, HR bisa mengembangkan strategi berdasarkan perkiraan permintaan SDM yang sudah dibuat. Strategi yang dibuat tentunya harus bisa memberikan solusi bagi kekurangan masalah SDM di perusahaan. HR bisa melakukan relokasi, rekrutmen, outsourcing, pelatihan, manajemen SDM, hingga melakukan perubahan kebijakan terkait SDM.

3. Faktor yang dipertimbangkan dalam perencanaan SDM
a. Pertumbuhan (Growth)
b. Perubahan (Change)
c. Teknologi (Technology)

4. Tahapan Perencanaan SDM:
a. Analisis tujuan organisasi
b. Melakukan Inventarisasi SDM saat ini
c. Perkiraan permintaan dan pasokan SDM
d. Memperkirakan kesenjangan manusia
e. Merumuskan rencana tindakan SDM
f. Pemantauan, penendaian dan umpan balik

\section{HRM MODEL}

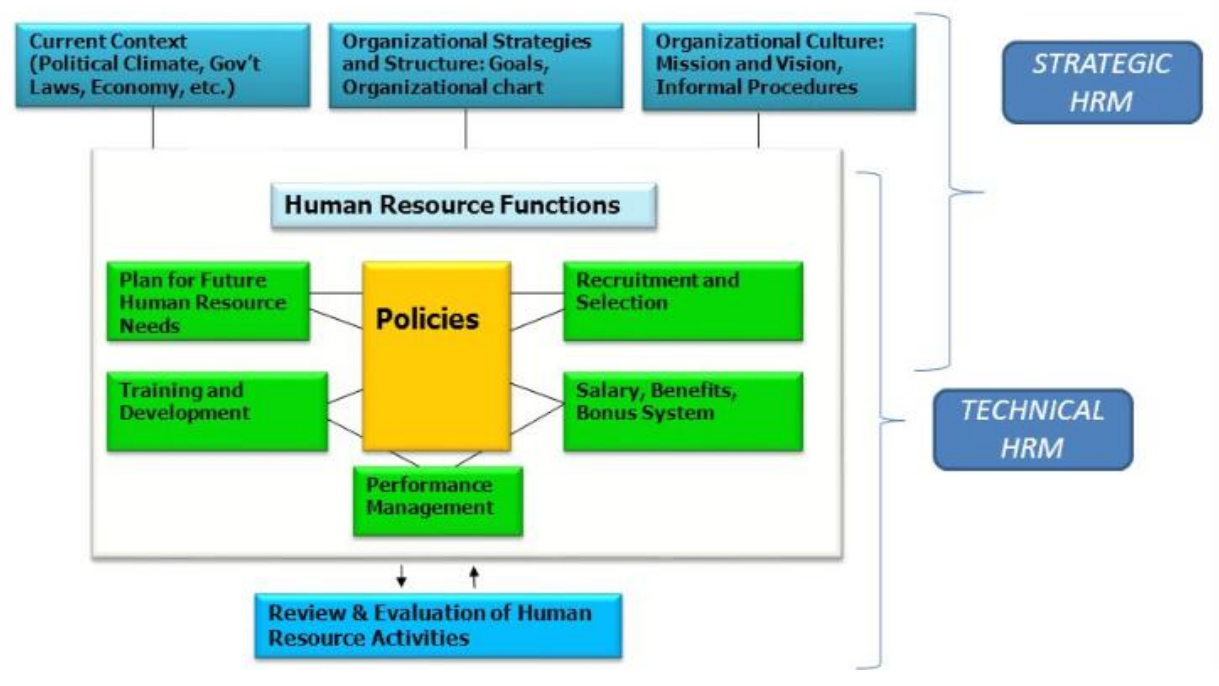

Gambar 8.1 Manajemen SDM dan Produktivitas Bidang Kesehatan 


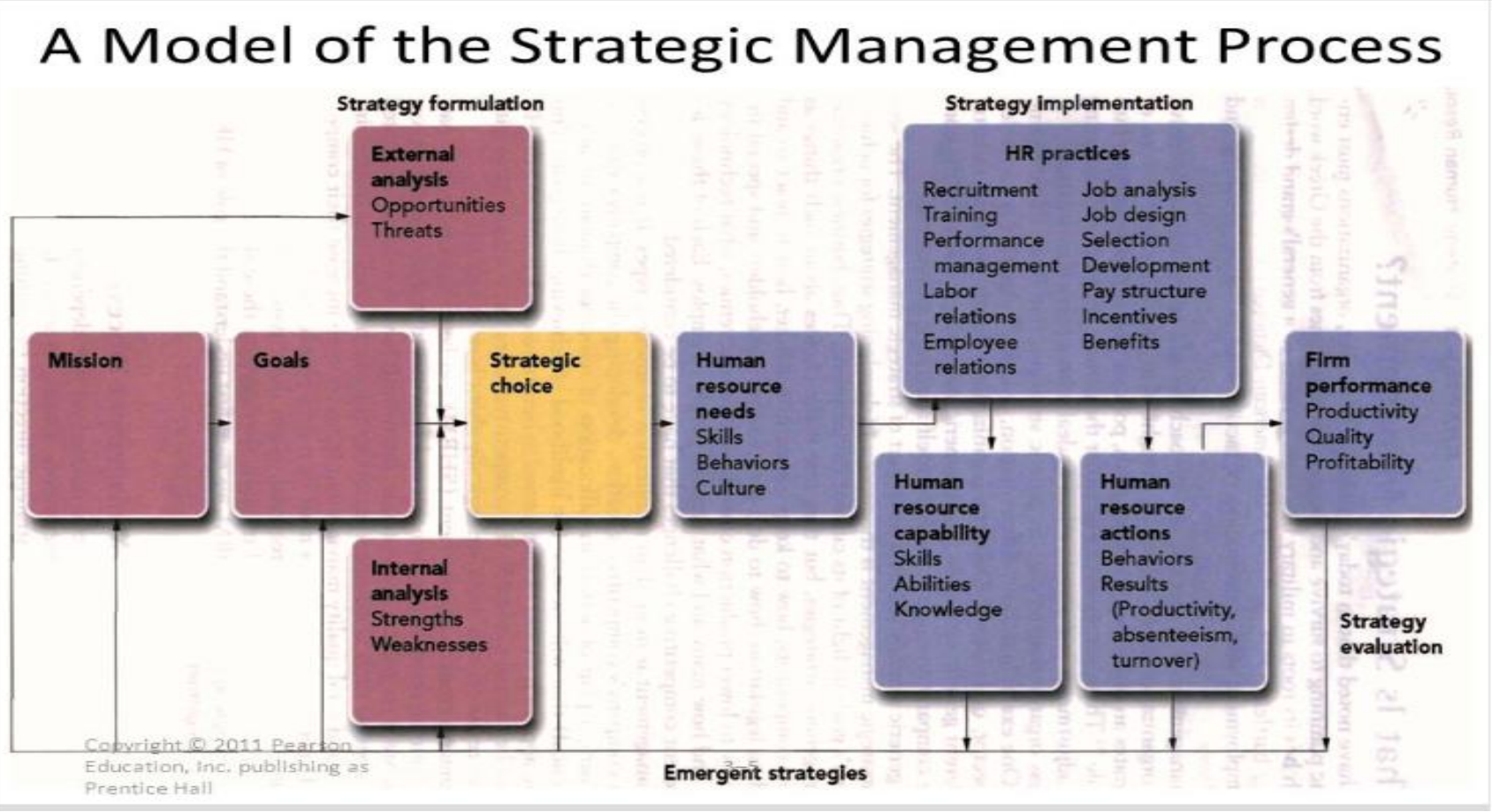

Gambar 8.2 Model proses manajemen stratejik

\section{Human Resource Management Functions}

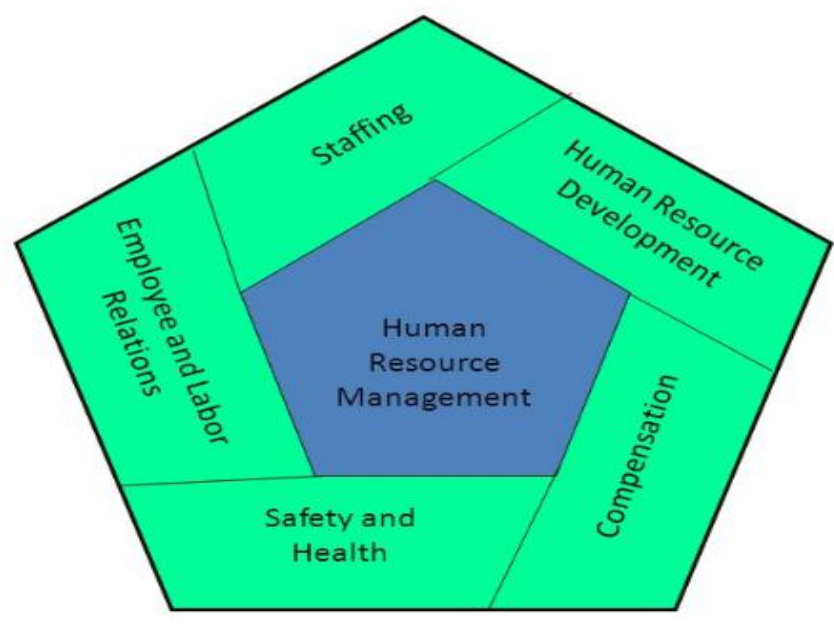

Q 2008 by Prentice $\mathrm{Hal}$

Gambar 8.3 Fungsi Manajemen SDM 


\section{Strategy and the Basic HR Process}

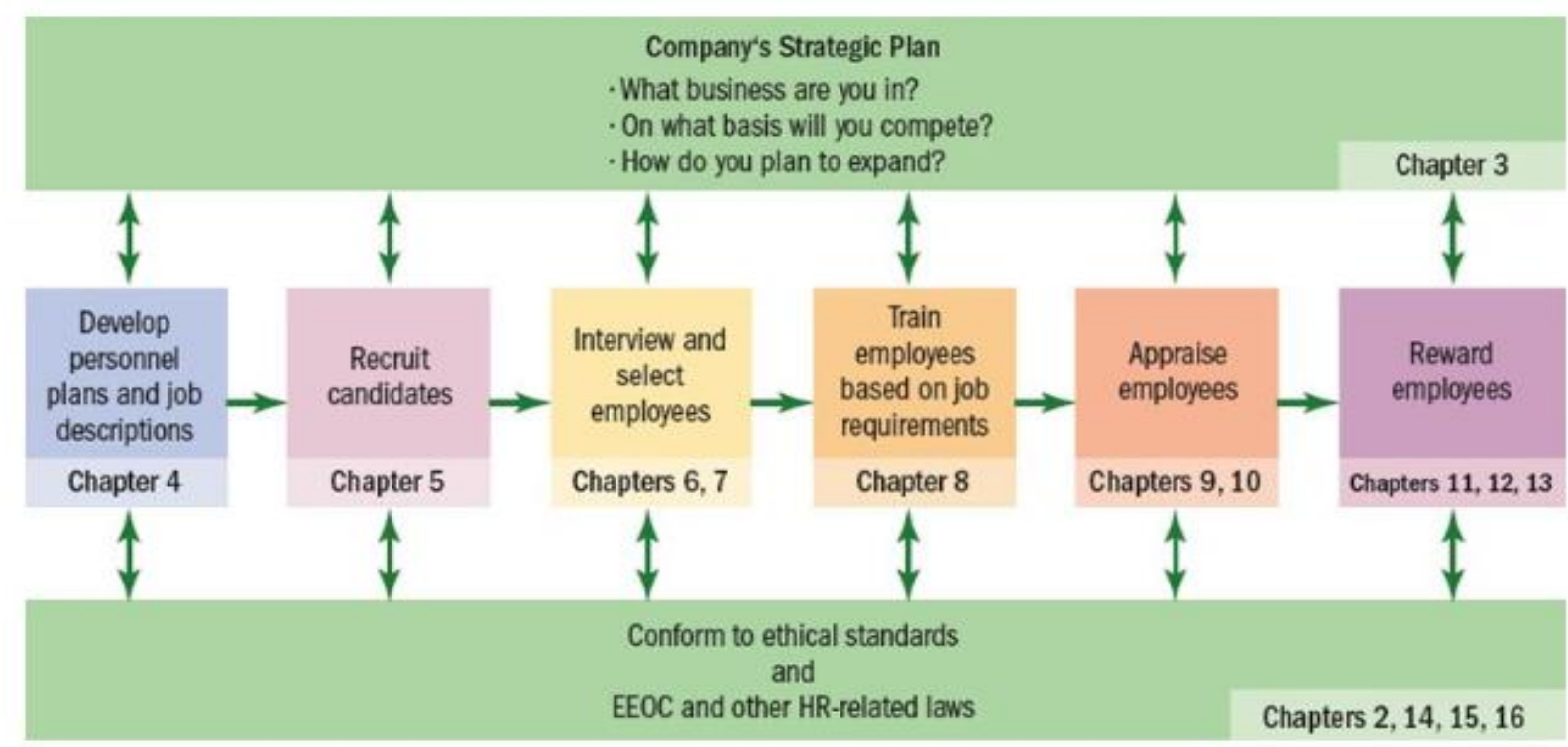

Gambar 8.4 Strategi dan dasar proses manajemen SDM

\section{Human Resource Management Process}

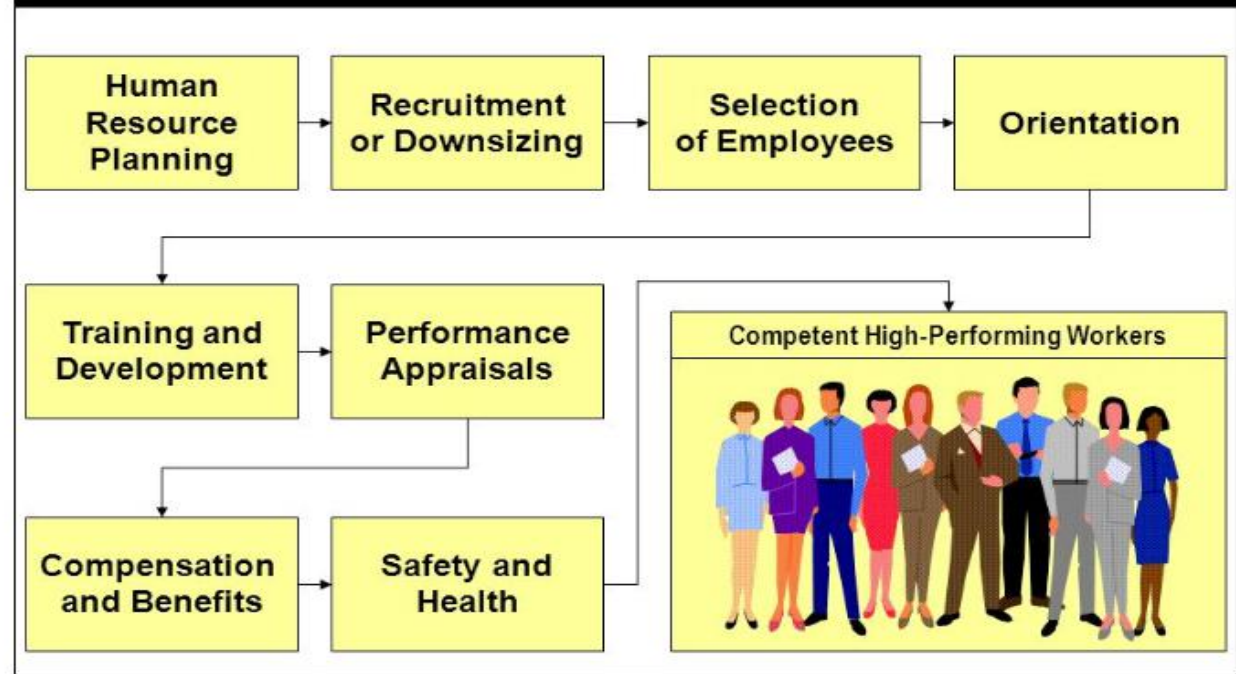

QPrentice Hall, 2001

Chapter 6

Gambar 8.5 Proses manajemen SDM 


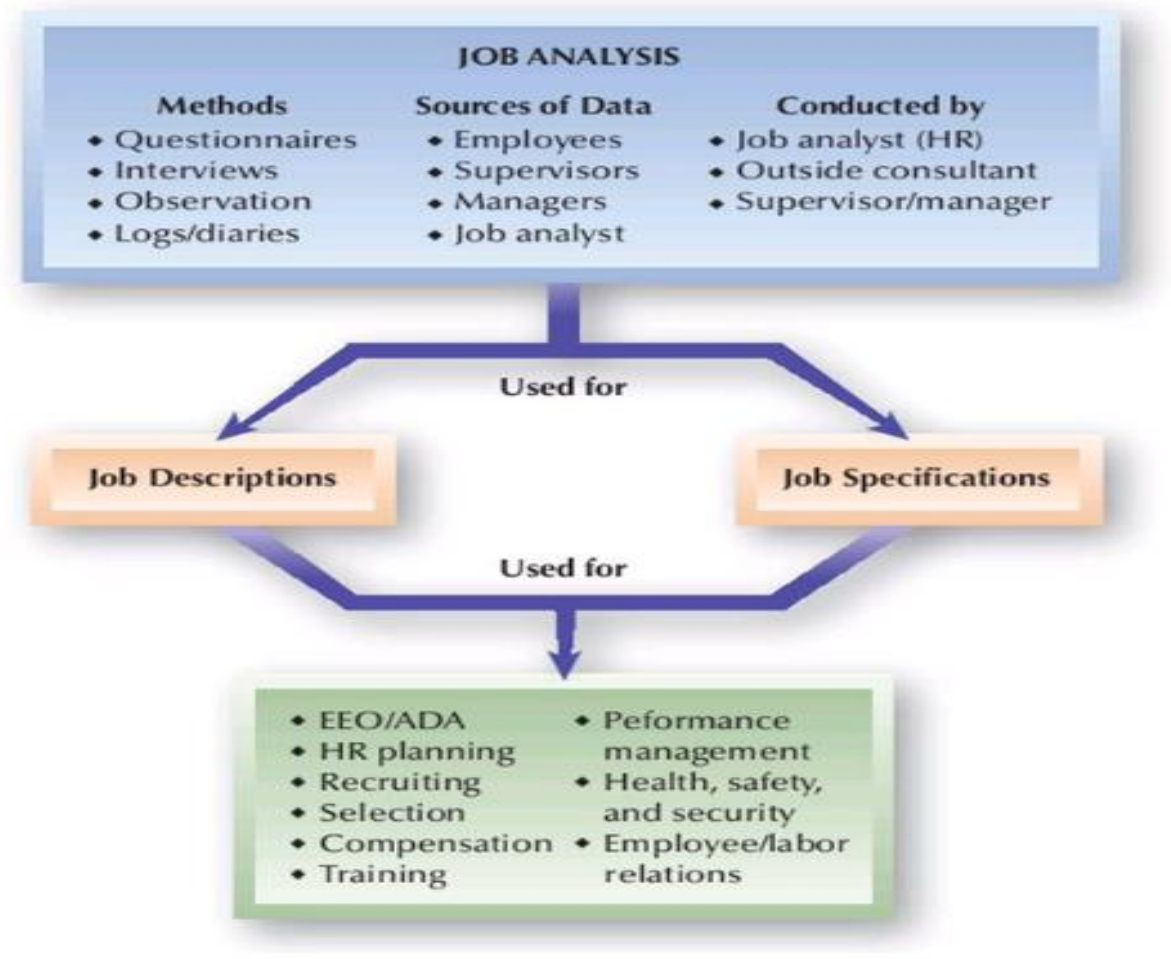

Gambar 8.6 Analisis pekerjaan

\section{Strategic Framework for Employee Recruiting}

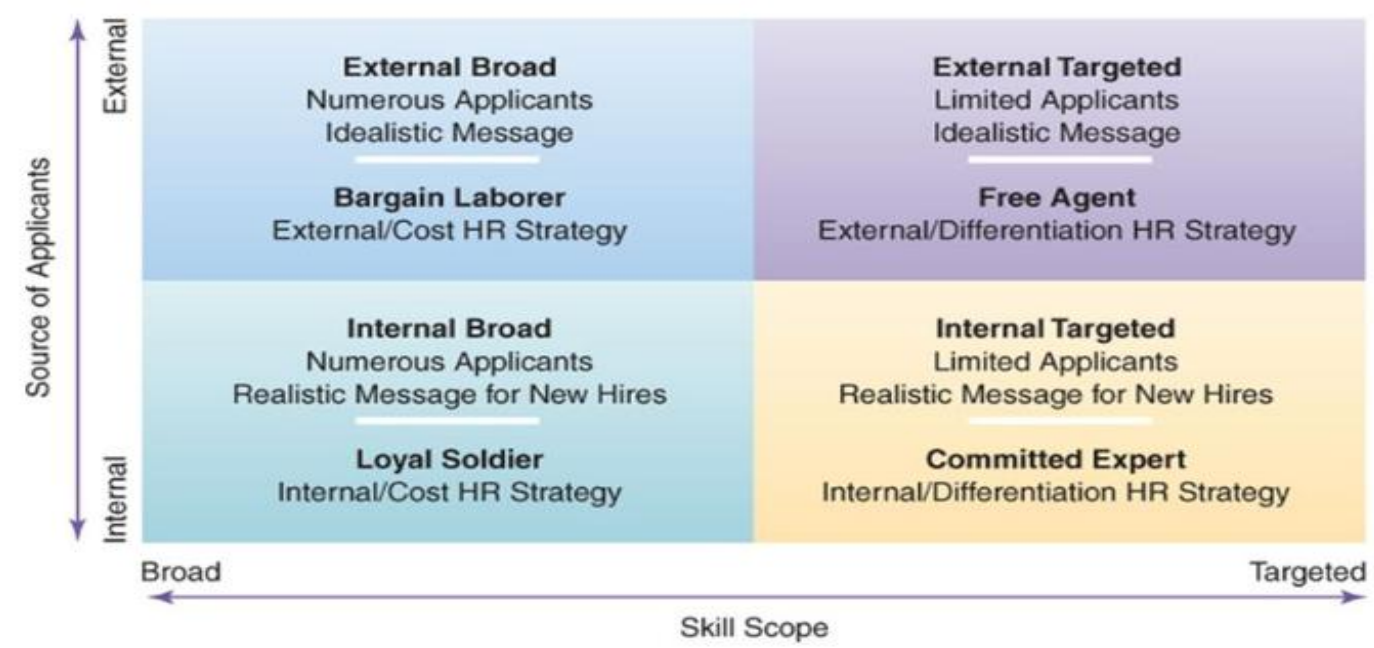

Gambar 8.7 Kerangka stratejik rekrutmen karyawan 


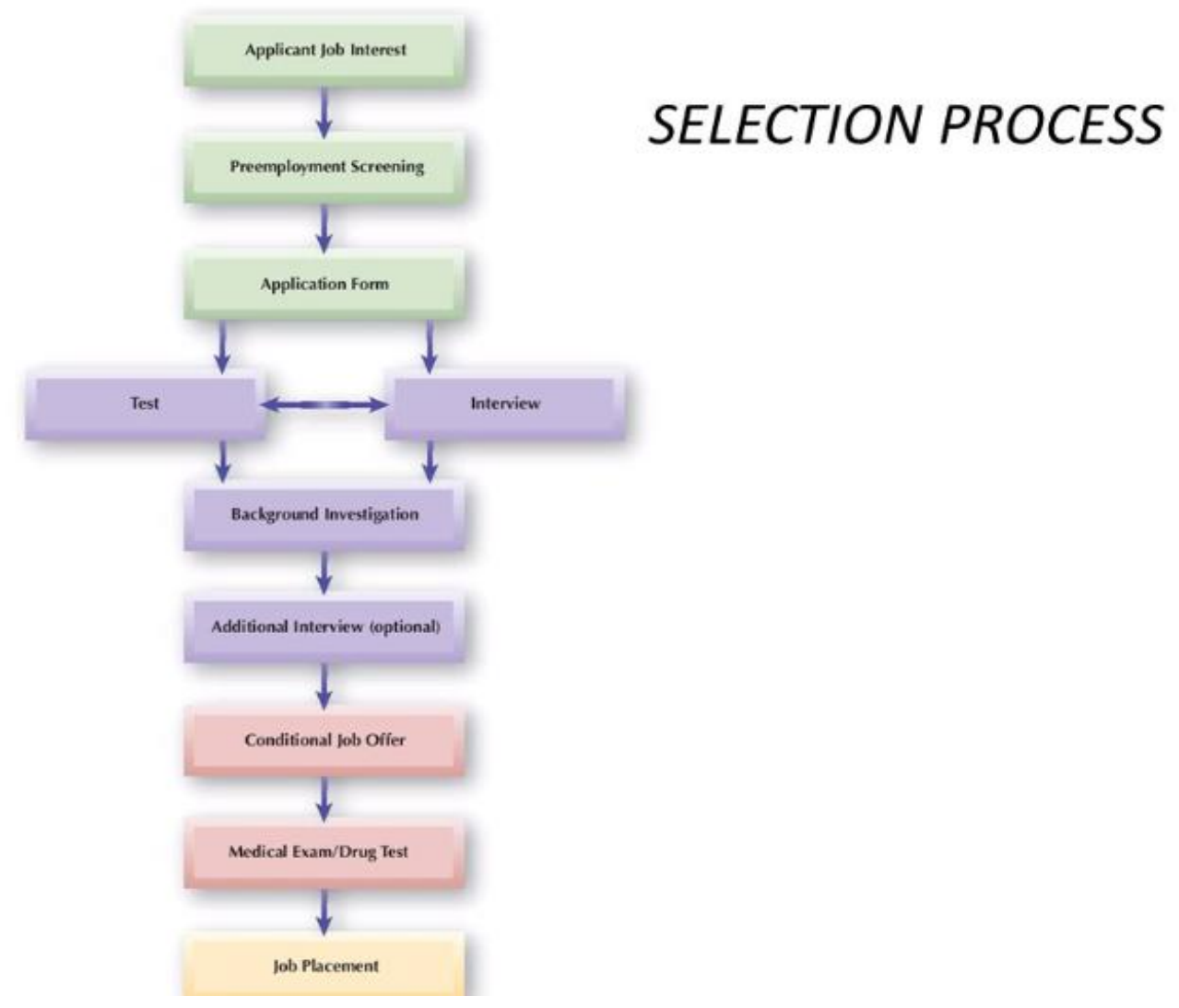

Gambar 8.8 Proses seleksi

\section{SYSTEMATIC TRAINING PROCESS}

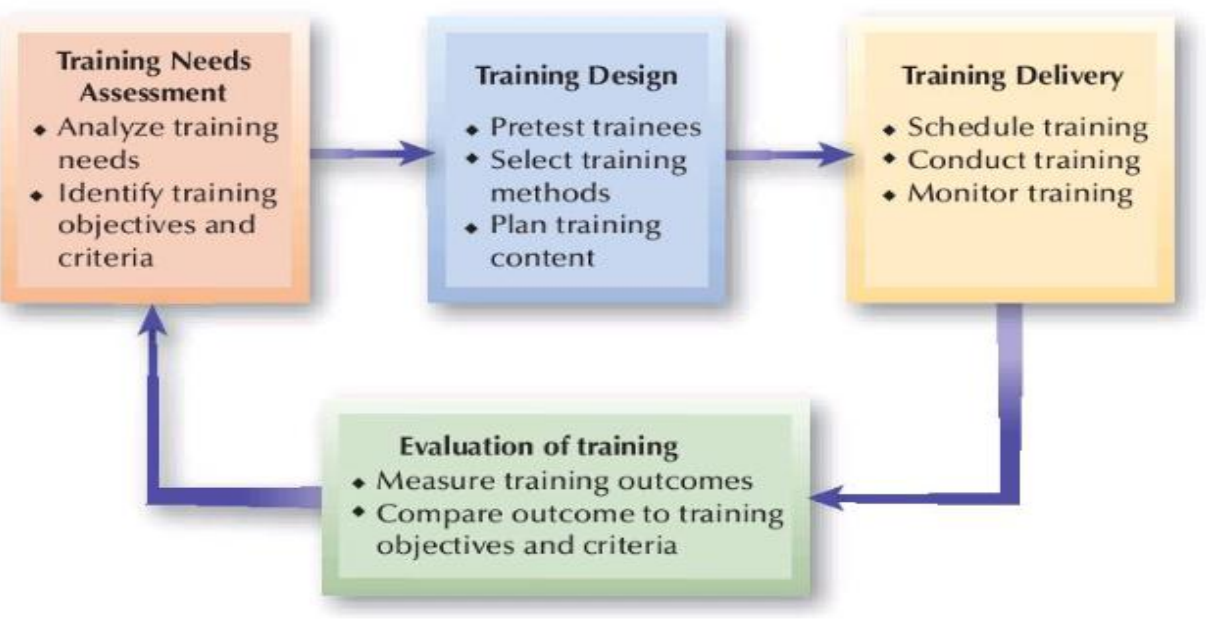

Gambar 8.9 Proses pelatihan sistematis 


\section{Training vs Development}

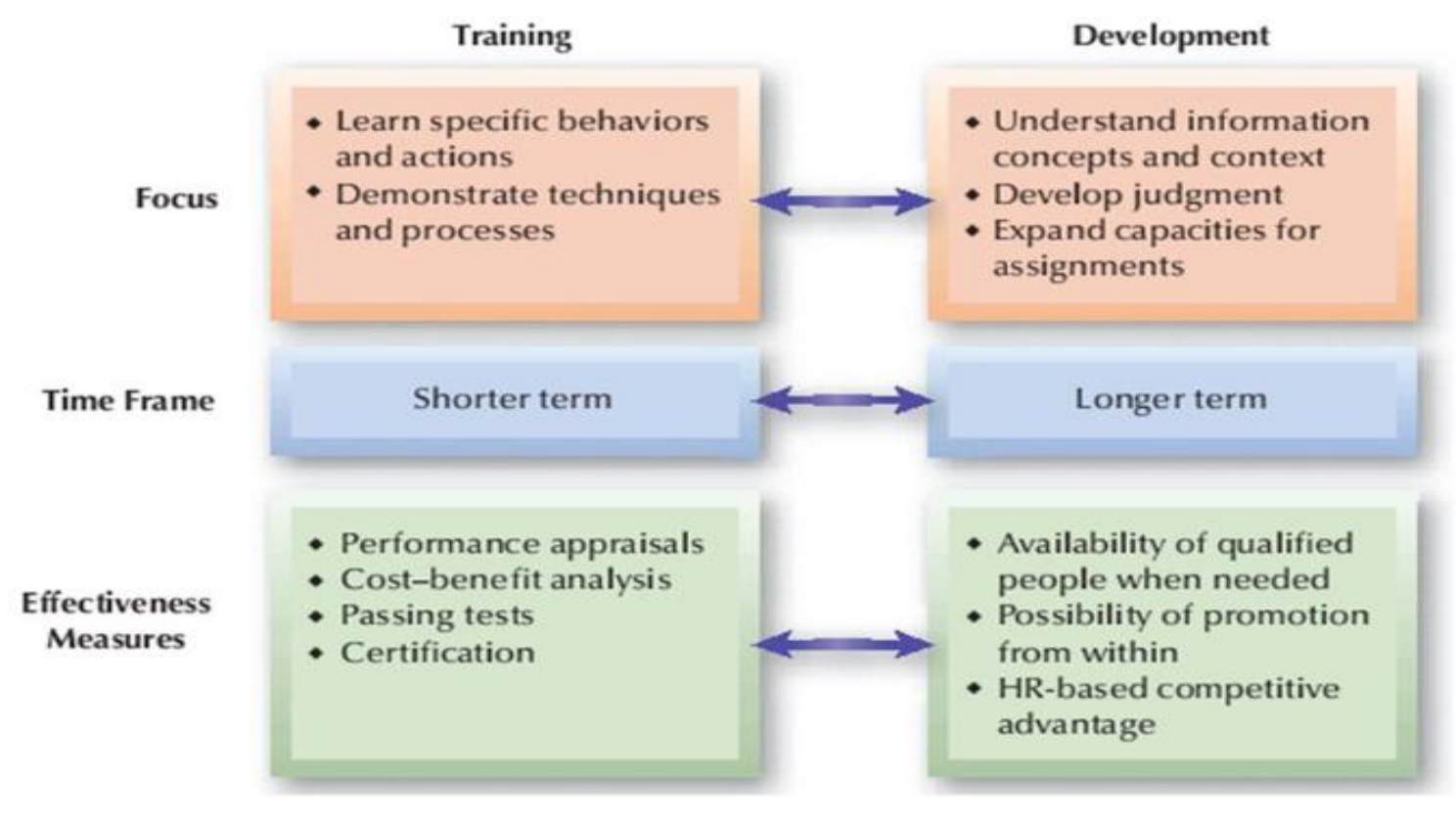

Gambar 8.10 Pelatihan dibanding pengembangan

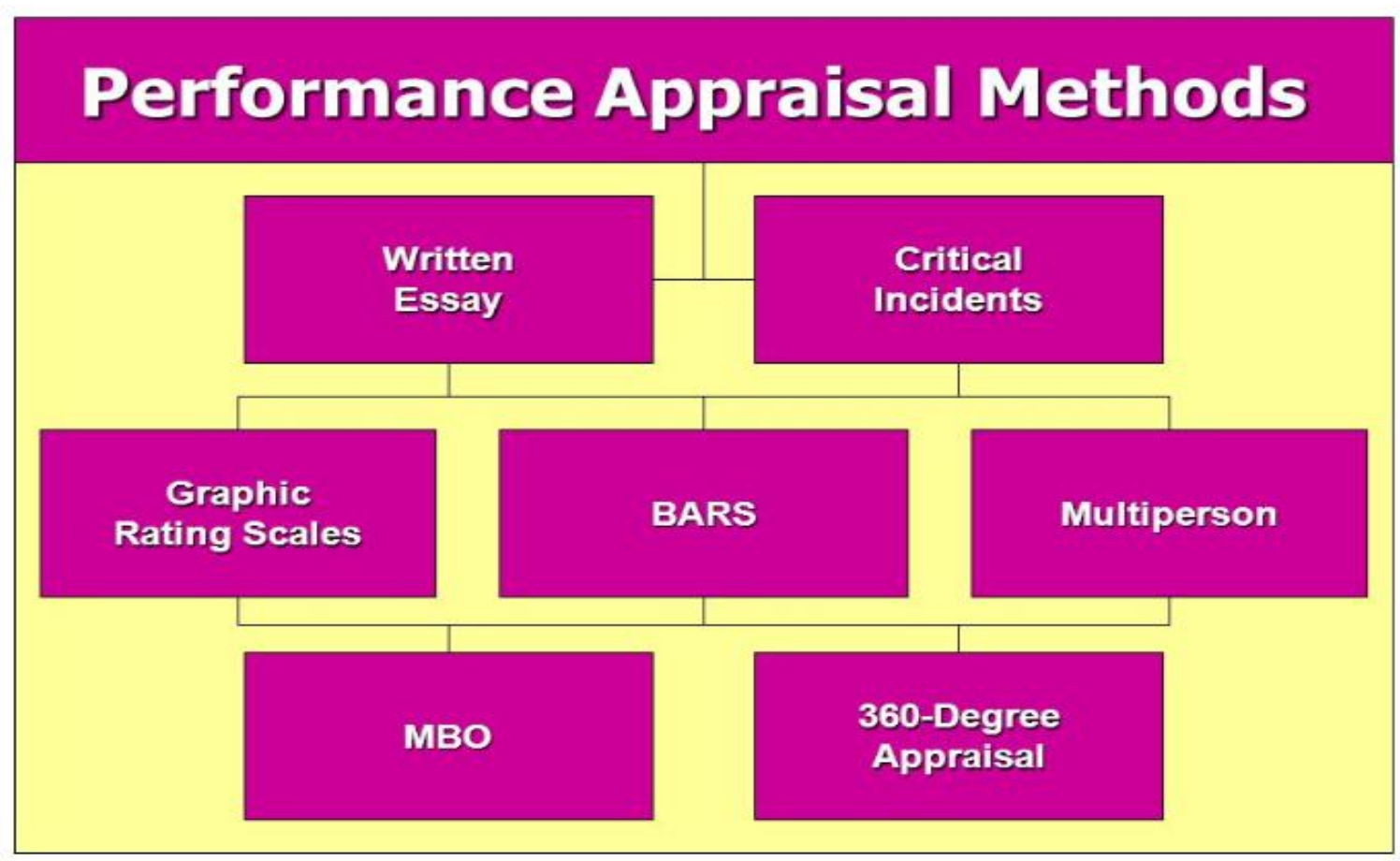

Gambar 8.11 Metode pencapaian performa/kinerja 


\section{Komponen Total Reward}

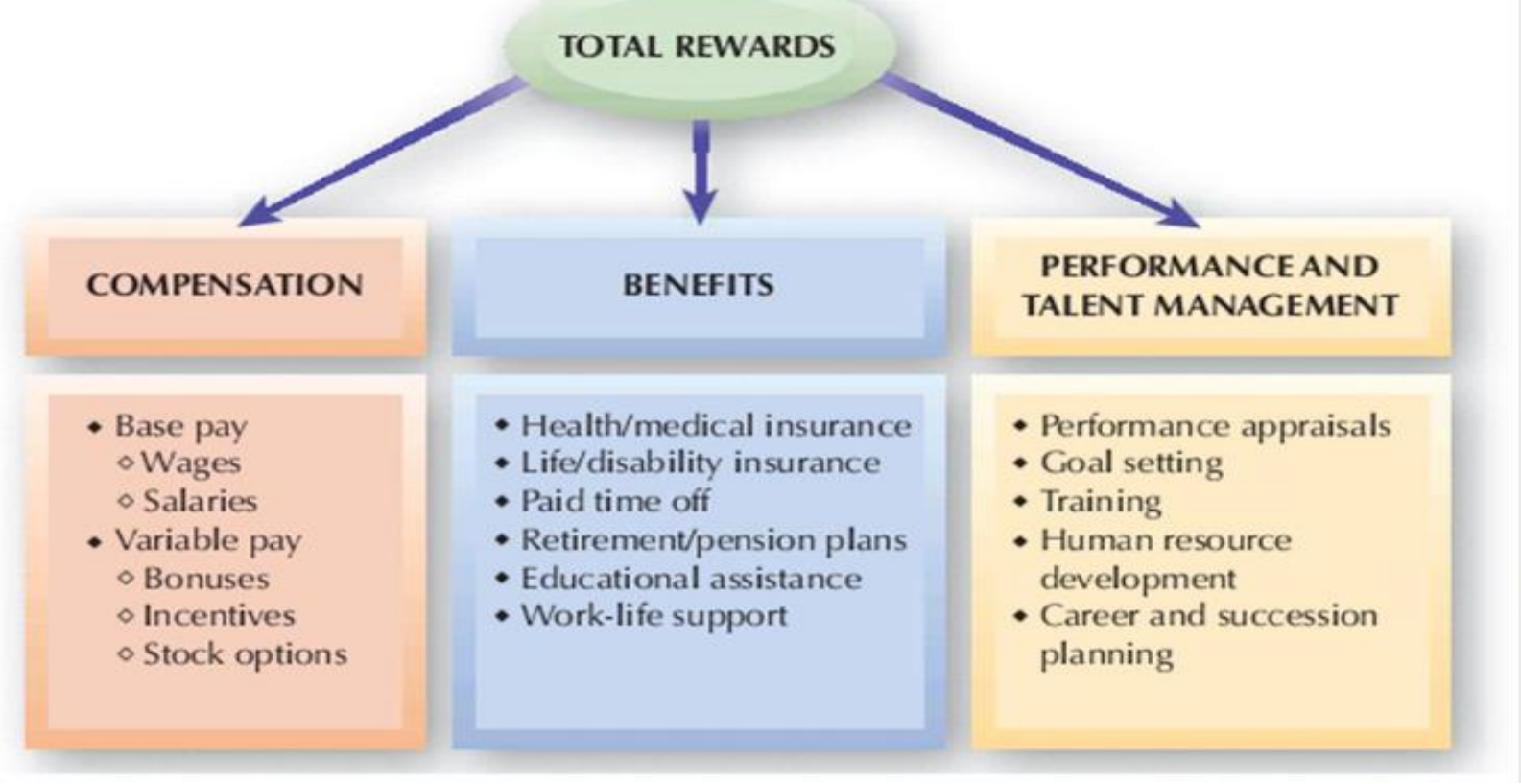

Gambar 8.12 Komponen penghargaan keseluruhan

\section{TEAM BUILDING PHASE}

\section{Forming}

Team acquaints and establishes ground rules.

Formalities are preserved and members are treated as strangers.

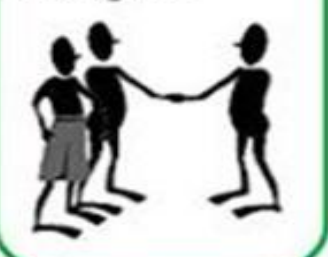

Storming Members start to communicate their feelings but still view themselves as individuals rather than part of the team. They resist control by group leaders and show hostility.

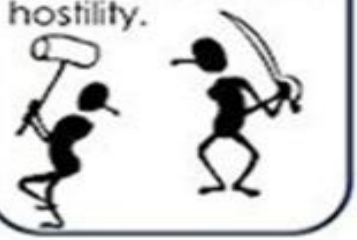

Adjourning The feam conducts an assessment of the year and implements a plan for transitioning roles and recognizing members' contributions. other viewpoints.

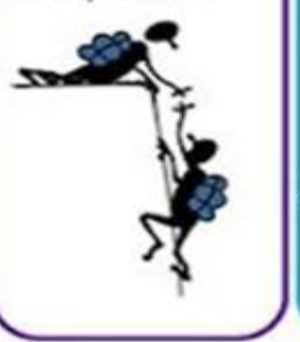

The team

works in an

trusting atmosphere where flexibility is the key and hierarchy is of little importance.

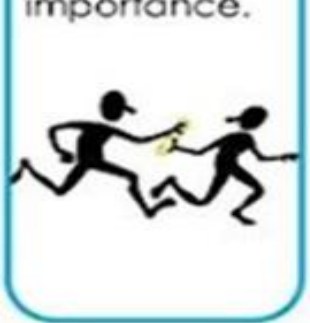

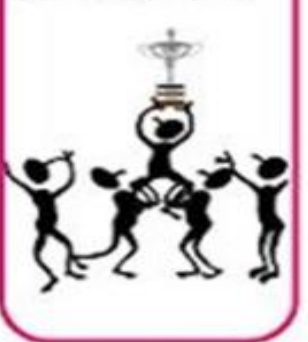

Gambar 9.13 Tahap pemgembangan tim/kelompok 


\section{Causes of Job Satisfaction}
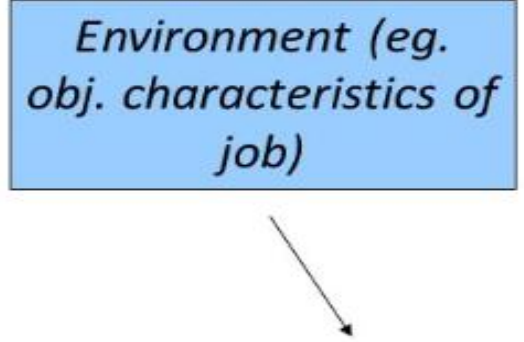

\section{Subjective interpretation of job environment}

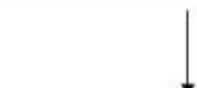

\section{Job Satisfaction}

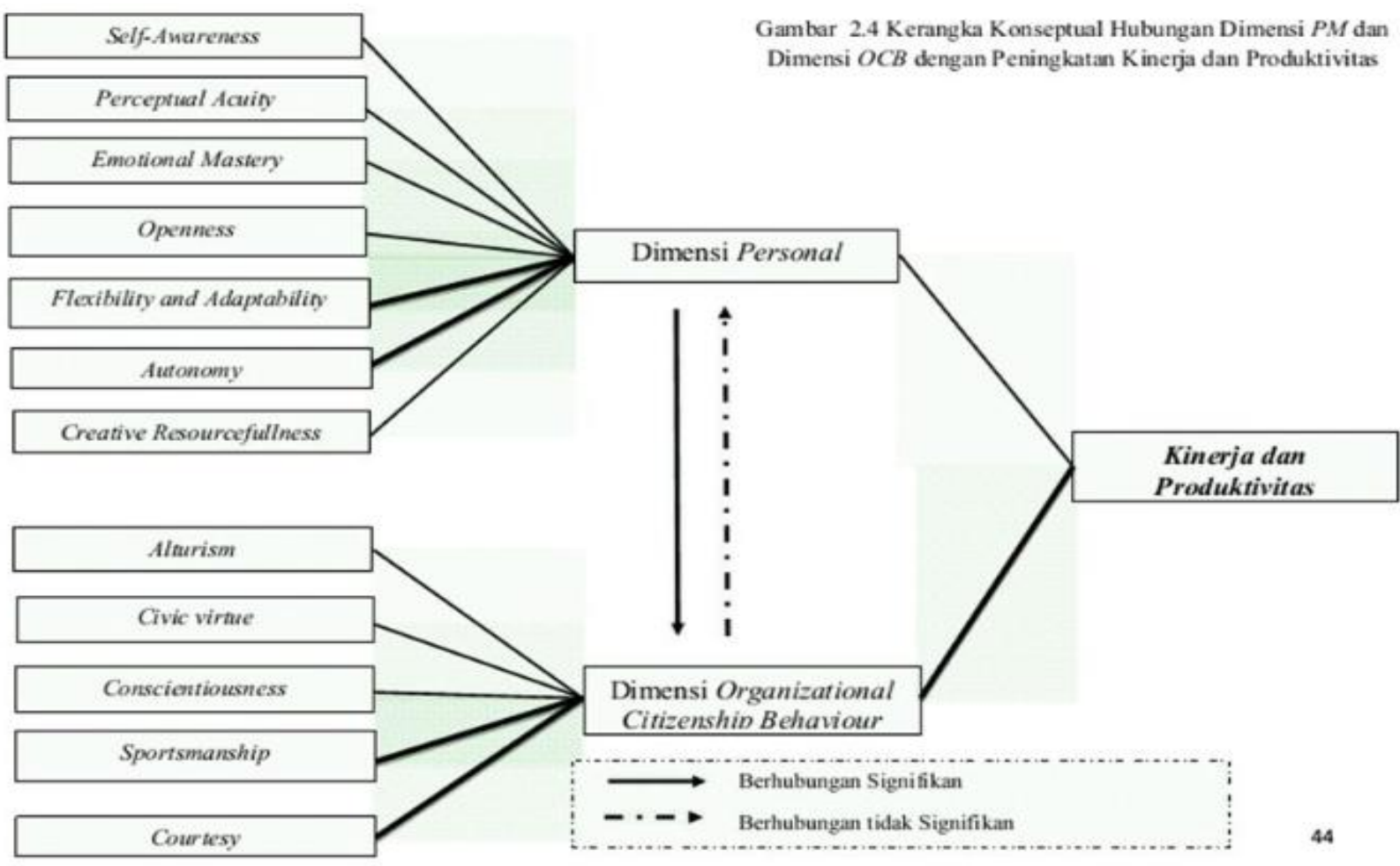

Gambar 8.15 Proses pencapaian kinerja dan produktivitas 


\section{MATERI IX}

\section{Promosi dan pemindahan SDM}

\section{A. Sub Materi 1: Permasalahan pemerintah terkait dengan sumber daya aparaturnya}

1. Kelembagaan birokrasi pemerintah yang besar dan didukung oleh sumber daya aparatur yang kurang profesional;

2. Mekanisme kerja yang sentralistik masih mewarnai kinerja birokrasi pemerintah;

3. Kontrol terhadap birokrasi pemerintah masih dilakukan oleh pemerintah, untuk pemerintah, dan dari pemerintah;

4. Patron klien $(\mathrm{KKN})$ dalam birokrasi pemerintah merupakan halangan terhadap upaya mewujudkan merirokrasi dalam birokrasi;

5. Tidak jelas dan bahkan cenderung tidak ada "sense of accountability" baik secara kelembagaan maupun secara individual

6. Jabatan birokrasi yang hanya menampung jabatan struktural danpengisiannya seringkali tidak berdasarkan kompetensi yang dibutuhkan;

7. Penataan sumber daya aparatur tidak disesuaikan dengan kebutuhan dan penataan kelembagaan birokrasi. (Thoha 2005:3).

\section{B. Sub Materi 2: Karier}

Kondisi yang menunjukkan adanya peningkatan status kepegawaian seseorang dalam suatu organisasi sesuai dengan jalur karir yang telah ditetapkan organisasi. Semua pekerjaan atau jabatan yang dipegang selama masa kerja seseorang. Menunjukkan perkembangan para karyawan secara individual dalam suatu jenjang atau kepangkatan yang dapat dicapai selama masa kerjanya dalam suatu organisasi. Karier merupakan suatu arah umum yang dipilih oleh seseorang untuk mengejar keseluruhan kehidupan kerjanya (Mondy dan Noe, 1996).

\section{Perencanaan Karier}

Perencanaan tentang kemungkinan-kemungkinan bagi seorang karyawan dan anggota suatu organisasi sebagai individu untuk meniti proses kenaikan 
pangkat dan jabatan sesuai persyaratan jabatan dan kemampuannya. Tidak harus dikonsentrasikan hanya pada peluang kenaikan jabatan, jika memang pada lingkungan kerja saat ini peluang tersebut sangat terbatas. Karakteristik dan kriteria pengelolaan karier dirancang berdasarkan pengembangan struktur organisasi sebab jalur karier ditentukan berdasarkan rentang struktur organisasi yang tersedia dalam organisasi. Persyaratan untuk duduk pada posisi tertentu sangat ditentukan oleh kompetensi yang dimiliki karyawan yang akan menduduki jabatan tersebut..

2. Mengapa perencanaan karir penting

a. Kesempatan untuk melakukan sesuatu yang membuat anda merasa senang.

b. Kesempatan untuk mencapai sesuatu yang berharga.

c. Kesempatan untuk mempelajari hal-hal baru, dan

d. Kesempatan untuk mengembangkan kecakapan dan kemampuan anda.

\section{Manfaat perencanaan karier}

a. Mengembangkan para karyawan yang dapat dipromosikan.

b. Menurunkan perputaran karyawan.

c. Mengungkap potensi karyawan.

d. Mendorong pertumbuhan.

e. Memuaskan kebutuhan karyawan.

f. Membantu pelaksanaan rencana kegiatan yang telah disetujui.

4. Unsur-unsur Program Perencanaan Karir.

a. Penilaian individu tentang kemampuan, minat, kebutuhan karir dan tujuan;

b. Penilaian organisasi tentang kemampuan dan kesanggupan pegawai;

c. Komunikasi informasi mengenai kebebasan memilih dan kesempatan karir pada organisasi; dan

d. Penyuluhan karir untuk menentukan tujuan-tujuan realistik dan rencana untuk pencapaiannya.

5. Dalam kursus penyuluhan karir, pegawai berusaha menjawab jenis-jenis pertanyaan : 
a. Kecakapan-kecakapan apakah yang sudah saya miliki, dan apakah kemungkinan-kemungkinannya untuk mengembangkan atau untuk mempelajari hal-hal yang baru?

b. Apakah sesungguhnya yang saya butuhkan untuk saya sendiri sepanjang mengenai pekerjaan?

c. Kemampuan dan kecakapan saya sekarang yang mana yang dapat saya berikan?

d. Apakah yang sesungguhnya diperlukan untuk pekerjaan-pekerjaan/jabatan-jabatan tertentu?

e. Latihan apakah yang diperlukan apabila saya memilih mengejar tujuan karir tertentu?

\section{Pengembangan karier}

Suatu kondisi yang menunjukkan adanya peningkatan-peningkatan status seseorang dalam suatu organisasi dalam jalur karir yang telah ditetapkan dalam organisasi yang bersangkutan. Bagaimanapun juga pengembangan karir masing-masing anggota dalam suatu organisasi tentunya tidak sama (bersifat unik).

\section{a. Pengembangan karier individual}

Secara individual, setiap anggota organisasi atau karyawan perusahaan harus siap mengembangkan diri dalam rangka meniti jenjang karirnya lebih lanjut. Ada enam kegiatan pengembangan karir yang dapat dilakukan masing-masing individu sebagai berikut:

1) Peningkatan PRESTASI KERJA sebagai dasar utama kegiatan pengembangan karir.

2) EXPOSURE, dalam arti berusaha untuk dikenal oleh para pengambil keputusan berkenaan dengan promosi, mutasi, dan kesempatan peningkatan karir lainnya.

3) PERMINTAAN BERHENTI, atau berpindah perusahaan, apabila dirasakan terdapat kesempatan pengembangan karir di tempat lain.

4) KESETIAAN ORGANISASIONAL, terutama untuk perusahaan-perusahaan yang melakukan penilaian karir berdasarkan jangka waktu kerja seorang karyawan di perusahaan tersebut. 
5) MENTOR DAN SPONSOR, umumnya adalah atasan langsung, yang memberikan bimbingan karir secara informal dan memberikan kesempatan-kesempatan karir dalam bentuk promosi dan nominasi untuk suatu jabatan.

6) KESEMPATAN UNTUK TUMBUH, yang dapat dicapai melalui peningkatan kemampuan karyawan, salah satunya melalui PROGRAM PENDIDIKAN DAN PELATIHAN

\section{Keberhasilan Karir Dipengaruhi Oleh :}

a. Pendidikan formal dan informal.

b. Pengalaman kerja dan keterampilan.

c. Sikap atasan.

d. Prestasi dan produktivitas kerja.

e. Bobot pekerjaan.

f. Lowongan jabatan.

\section{Jalur karier :}

4 jalur karier yang biasa digunakan oleh organisasi:

a. Jalur karier tradisional,

Suatu tipe jalur karier di mana karyawan mengalami kemajuan secara vertikal ke atas di dalam suatu organisasi dan suatu jabatan tertentu ke jabatan berikutnya.

b. Jalur karier jaringan,

Jalur karier yang meliputi urutan urutan (sekuensi) jabatan secara vertikal dan horizontal. Mengakui adanya saling pertukaran pengalaman pada level tertentu dan kebutuhan pengalaman yang luas pada suatu level sebelum promosi ke level yang lebih tinggi.

c. Jalur karier lateral,

Jalur karier yang memungkinkan seseorang memperoleh revitalisasi dan menemukan tantangan baru pada jenjang posisi yang sama karena jumlah jabatan yang akan ditempati sangat terbatas. Dalam hal ini tidak ada promosi dan kenaikan upah, namun nilai seseorang menjadi lebih tinggi dengan ditempatkannya pada posisi yang lebih menantang

d. Jalur karier rangkap. 
Jalur karir ganda yang diberikan kepada seseorang karena pengetahuan teknisnya sebagai penghargaan kepadanya. Hal ini biasanya terjadi pada perusahaan berteknologi tinggi dan karyawan tersebut tidak masuk dalam jajaran manajemen struktural.

9. Sasaran karier

Posisi di waktu yang akan datang di mana seseorang harus "berjuang" untuk mencapainya sebagai bagian dari jenjang karirnya. Titik sentral yang memungkinkan seseorang meniti suatu jalur karir pada dasarnya terletak pada dua hal utama:

a. Kemampuan intelektual

b. Kepribadian dalam kepemimpinan

10. Tingkatan karir , arir Percobaan, Karir Pembentukan/Kemajuan,

a. Karir Tengah

b. Karir Akhir.

11. Characteristic of Managerial Careers in the 21st Century'

a. Spesialisasi pengetahuan dasar teknis (a knowledge-based technical speciality)

b. Pengalaman bidang khusus dan Internasional (cross-functional and International experience)

12. Mengapa mengadakan perencanaan karir?

Merupakan fungsi kepegawaian yang relatif baru dan program-program masih jarang, kecuali dalam organisasi-organisasi yang besar atau maju. Akan tetapi keterlibatan organisasi dalam perencanaan karir makin bertambah. Banyak calon pegawai, khususnya calon-calon yang berpendidikan tinggi, menginginkan suatu karir, bukan "hanya suatu jabatan" saja.

\section{Sub Materi 3: Promosi}

Promosi adalah penghargaan dengan kenaikan jabatan dalam suatu organisasi ataupun instansi baik dalam pemerintahan maupun non pemerintah (swasta). Menurut Rivai (2009:199) promosi terjadi apabila seorang karyawan dipindahkan dari satu pekerjaan ke pekerjaan lain yang lebih tinggi dalam pembayaran, tanggung jawab, dan atau level. Umumnya diberikan sebagai penghargaan, hadiah (reward 
system) atas usaha dan prestasinya di masa lampau. Promosi dapat terjadi tidak hanya bagi mereka yang menduduki jabatan manajerial, akan tetapi juga bagi mereka yang pekerjaannya bersifat teknikal dan non-manajerial.

\section{Tujuan Promosi}

Menurut Sastrohadiwirjoyo (2002:261), tujuan promosi yaitu :

a. Meningkatnya Moral Kerja

Promosi merupakan salah satu faktor dominan yang dapat dilakukan perusahaan demi terwujudnya tujuan peningkatan moral kerja karyawan.

b. Meningkatnya Disiplin Kerja

c. Terwujudnya Iklim Organisasi yang Menggairahkan

d. Meningkatnya Produktivitas Kerja

\section{Dasar-dasar promosi}

Menurut Siagian (2005:170), organisasi pada umumnya menggunakan dua dasar utama dalam mempertimbangkan seseorang untuk dipromosikan yaitu:

\section{Prestasi kerja}

Promosi yang didasarkan pada prestasi kerja menggunakan hasil penilaian atas hasil karya yang sangat baik. Dengan demikian promosi tersebut dapatdipandang sebagai penghargaan organisasi atas prestasi kerja anggotanya.

\section{Senioritas}

Promosi berdasarkan senioritas berarti bahwa pegawai yang paling berhak dipromosikan ialah yang masa kerjanya paling lama.Banyak organisasi menempuh cara ini dengan tiga poin pertimbangan yaitu :

a. Sebagai penghargaan atas jasa-jasa seseorang paling sedikit dilihat dari segi loyalitas kepada organisasi.

b. Penilaian biasanya bersifat obyektif karena cukup dengan membandingkan masa kerja orang-orang tertentu yang dipertimbangkan untuk dipromosikan.

c. Mendorong organisasi mengembangkan para pegawainya karena pegawai yang paling lama berkarya akhirnya mendapat promosi. 


\section{Azas-Azas Promosi Karyawan/Pegawai}

Azas-azas promosi jabatan menurut Hasibuan (2002:108), yaitu :

a. Kepercayaan

Promosi hendaknya berazaskan pada kepercayaan atau keyakinan mengenai kejujuran, kemampuan dan kecakapan karyawan/pegawai yang bersangkutan baik pada jabatan tersebut.

b. Keadilan

Promosi jabatan berazaskan keadilan terhadap penilaian kejujuran, kemampuan dan kecakapan karyawan. Penilaian harus jujur dan obyektif tidak pilih kasih atau like and dislike.

c. Formasi

Promosi harus berdasarkan formasi yang ada. Karena promosi karyawan/pegawai hanya mungkin dilakukan jika ada formasi jabatan yang lowong. Untuk itu harus ada uraian pekerjaan/jabatan yang akan dilaksanakan karyawan/pegawai.

\section{Pedoman Promosi Karyawan}

Pedoman yang dijadikan untuk mempromosikan karyawan menurut Malayu (2006 : 106), adalah :

a. Pengalaman Pengalaman (senioritas) yaitu promosi yang didasarkan pada lamanya pengalaman kerja karyawan. Pertimbangan promosi adalah pengalaman kerja seseorang, orang yang terlama bekerja dalam perusahaan mendapat prioritas pertama dalam tindakan promosi.

b. Kecakapan Kecakapan (ability) yaitu seseorang akan dipromosikan berdasarkan penilaian kecakapan. Pertimbangan promosi adalah kecakapan, orang yang cakap atau ahli mendapat prioritas pertama untuk dipromosikan.

c. Kombinasi Kecakapan dan Pengalaman. Kombinasi kecakapan dan pengalaman yaitu promsi yang berdasarkan pada lamanya pengalan dan kecakapan. Pertimbangan promosi adalah sberdasarkan lamanya dinas, ijazah pendidikan formal yang dimiliki, dan hasil ujian kenaikan golongan. Jika seseorang lulus dalam ujian maka hasil ujian kenaikan tersebut dijadikan dasar untuk mempromosikan seseorang. 


\section{Syarat-syarat promosi}

Persyaratan promosi untuk setiap perusahaan tidak selalu sama tergantung kepada perusahaan/lembaga masing-masing. Menurut Handoko (1999) syarat-syarat promosi pada umunya sebagai berikut.
1. Kejujuran
6. Loyalitas
2.Disiplin
7. Kepemimpinan
3. Prestasi kerja
8. Komunikatif
4. Kerjasama
9. Pendidikan
5. Kecakapan

\section{Jenis-jenis Promosi Pegawai}

a. Kenaikan Pangkat Penyesuaian Ijazah

Kenaikan pangkat penyesuaian ijazah dapat diberikan kepada Pegawai setelah yang bersangkutan mengikuti ujian penyesuaian pangkat yang diselenggarakan oleh instansi dan dinyatakan lulus serta memenuhi persyaratan lainnya yang ditentukan.

b. Kenaikan Pangkat Pilihan

Berada satu tingkat di bawah jenjang pangkat terendah yang ditentukan untuk jabatan yang didudukinya;

1) Menunjukkkan prestasi kerja luar biasa baiknya;

2) Menemukan penemuan baru yang bermanfaat bagi negara

3) Sekurang-kurangnya telah 1 (satu) tahun dalam pangkat terakhir;

4) Sekurang-kurangnya telah 1 (satu) tahun dalam jabatan struktural yang didudukinya (dihitung kumulatif dalam tingkat jabatan struktural yang sama);

5) Setiap unsur DP-3 sekurang-kurangnya bernilai baik dalam 2 (dua) tahun terakhir.

\section{Jenis Kenaikan Pangkat Pilihan}

a. Kenaikan Pangkat Reguler

Syarat Kenaikan Pangkat Reguler :

1) Tidak menduduki jabatan struktural/fungsional tertentu; Diangkat dalam jabatan struktural dengan pangkat masih dibawah jenjang pangkat yang ditentukan tetapi telah 4 tahun dalam pangkat terakhir yang dimiliki; 
Menduduki jabatan struktural dan pangkatnya telah mencapai jenjang pangkat terendah yang ditentukan untuk jabatan itu; atau sedang tugas belajar dan sebelumnya menduduki jabatan struktural/fungsional tertentu;

2) Sekurang-kurangnya telah 4 (empat) tahun dalam pangkat terakhir;

3) Setiap unsur DP-3 sekurang-kurangnya bernilai baik dalam 2 (dua) tahun terakhir; dan

4) Tidak melampaui pangkat atasan langsungnya.

b. Kenaikan Pangkat Anumerta

1) Kenaikan pangkat anumerta diberikan setingkat lebih tinggi tmt. PNS/Karyawan tetap yang bersangkutan meninggal;

2) CPNS/karyawan tetap yang meninggal, diangkat menjadi PNS/karyawan tetapterhitung mulai awal bulan yang bersangkutan meninggal dan berlaku ketentuan sebagaimana dimaksud dalam point a;

3) Keputusan kenaikan pangkat anumerta diberikan sebelum PNS/Karyawan tetap yang meninggal tersebut dimakamkan.

c. Kenaikan Pangkat Pengabdian

1) Kenaikan pangkat pengabdian setingkat lebih tinggi diberikan tmt. PNS yang bersangkutan dinyatakan cacat karena dinas dan tidak dapat bekerja lagi dalam semua jabatan negeri;

2) CPNS yang cacat karena dinas dan dinyatakan tidak dapat bekerja lagi dalam semua jabatan negeri, diangkat menjadi PNS dan berlaku ketentuan.

\section{Promosi Jabatan}

Handoko (2004 : 47) menjelaskan bahwa promosi jabatan pada umumnya dapat memberikan motivasi yang positif terhadap karyawan dalam bekerja, beberapa dampak positf tersebut diantaranya adalah sebagai berikut :
a. Tingkat kedisiplinan tinggi
b. Meningkatnya semangat kerja karyawan
c. Motivasi tinggi
d. Tingkat absensi menurun
e. Kinerja karyawan meningkat 
Melalui penilaian prestasi kerja akan diketahui seberapa baik Ia telah melaksanakan tugas-tugas yang dibebankan kepadanya, sehingga perusahaan dapat menetapkan balas jasa yang sepantasnya atas prestasi kerja tersebut. Penilaian prestasi kerja juga dapat digunakan perusahaan untuk mengetahui kekurangan dan potensi seorang karyawan.

\section{Sub Materi 4: Demosi}

Menurut Suratman (1998) demosi adalah penurunan jabatan dalam suatu instansi yang biasa dikarenakan oleh berbagai hal, contohnya adalah keteledoran dalam bekerja. Turun jabatan biasanya diberikan pada karyawan yang memiliki kinerja yang kurang baik atau buruk serta bisa juga diberikan ada karyawan yang bermasalah sebagai sanksi hukuman Demosi merupakan suatu hal yang sangat dihindari oleh setiap pekerja karena dapat menurunkan status, jabatan, dan gaji. Namun, demosi atau turun jabatan ini biasa dilakukan oleh beberapa instansi ataupun perusahaan demi peningkatan kualitas kerja, dan juga sebagai motivasi bagi karyawannya agar mau berusaha untuk memperoleh yang diinginkan. Mendapatkan promosi dan menghindari demosi.

Menurut Handoko (2004 : 48) ada beberapa dampak yang dapat timbul dari kebijakan demosi karyawan. Adapun beberapa dampak tersebut adalah sebagai berikut :

a. Ketidakpuasan karyawan

b. Munculnya berbagai keluhan dari karyawan

c. Tidak adanya semangat kerja

d. Menurunnya disiplin kerja

e. Tingkat absensi yang tinggi

f. Pemogokan kerja Apabila karyawan memiliki produktivitas dan motivasi kerja yang tinggi, maka laju roda pun akan berjalan kencang, yang akhirnya akan menghasilkan kinerja dan pencapaian yang baik bagi perusahaan.

\section{E. Sub Materi 5: Mutasi}

Mutasi atau transfer menurut Wahyudi (1995 )adalah perpindahan pekerjaan seseorang dalam suatu organisasi yang memiliki tingkat level yang sama dari posisi perkerjaan sebelum mengalami pindah kerja. Kompensasi gaji, tugas dan tanggung jawab yang baru umumnya adalah sama seperti sedia kala. Mutasi atau rotasi kerja 
dilakukan untuk menghindari kejenuhan karyawan atau pegawai pada rutinitas pekerjaan yang terkadang membosankan serta memiliki fungsi tujuan lain supaya seseorang dapat menguasai dan mendalami pekerjaan lain di bidang yang berbeda pada suatu perusahaan. Transfer terkadang dapat dijadikan sebagai tahapan awal atau batu loncatan untuk mendapatkan promosi di waktu mendatang. Hakekatnya mutasi adalah bentuk perhatian pimpinan terhadap bawahan.

\section{Prinsip Mutasi}

Prinsip mutasi adalah Memutasikan karyawan kepada posisi yang tepat dan pekerjaan yang sesuai atau " The right man in the right place ", agar semangat dan produktifitas kerjanya meningkat (Hasibuan 2005:102). Kemudian prinsip mutasi berdasarkan PP No. 100 Tahun 2000 sama dengan prinsip dalam promosi jabatan yaitu berdasarkanprinsip profesionalisme sesuai dengan kompetensi, prestasi kerja, dan jenjang pangkatyang ditetapkanuntuk jabatan itu serta syarat obyektif lainnya tanpa membedakan jenis kelamin, suku, agama, ras, atau golongan.

2. Tujuan mutasi

Tujuan mutasi menurut Mudjiono (2000) adalah sebagai berikut :

a) Meningkatkan poduktivitas kayawan.

b) Menciptakan keseimbangan anatar tenaga kerja dengan komposisi pekejaan atau jabatan.

c) Memperluas atau menambah pengetahuan karyawan.

d) Menghilangkan rasa bosan/jenuh tehadap pekerjaannya.

e) Memberikan perangsang agar karyawan mau berupaya meningkatkan karir yang lebih tinggi.

f) Alat pendorong agar spirit kerja meningkat melalui pesaingan terbuka.

g) Menyesuaikan pekerjaan dengan kondisi fisik karyawan.

3. Manfaat Mutasi menurut Siagian( 2011:172)
a. Pengalaman baru
b. Cakrawala pandangan yang lebih luas
c. Tidak terjadi kebosanan atau kejenuhan
d. Perolehan pengetahuan dan keterampilan baru
e. Perolehan perspektif baru mengenai kehidupan organisasional 
f. Persiapan untuk menghadapi tugas baru, misalnya karena promosi

g. Motivasi dan kepuasan kja yang lebih tinggi berkat tantangan dan situasi baru yang dihadapi

\section{Dasar-Dasar Mutasi}

Ada tiga dasar/landasan pelaksanaan mutasi karyawan yang kita kenal merit system, seniority system, dan spoiled system (Hasibuan 102-103)

\section{a. Merit system}

Merit system adalah mutasi karyawan yang didasarkan atas landasanyangbersifat ilmiah, objektif, dan hasil prestasi kerjanya. Merit sistem atau career system ini merupakan dasar mutasi yang baik karena:

1) Output dan produktifitas kerja meningkat;

2) Semangat kerja meningkat;

3) Jumlah kasalahan yang diperbuat menurun;

4) Absensi dan disiplin karyawan membaik;

5) Jumlah kecelakaan akan menurun.

\section{b. Seniority system}

Seniority system adalah mutasi yang didasarkan atas landasan masa kerja, usia, dan pengalaman kerja dari karyawan bersangkutan. Sistem mutasi seperti ini tidak objektif karena kecakapan orang yamg dimutasikan berdasarkan senioritas belum tentu mampu memangku jabatan baru.

\section{c. Spoil system}

Spoil system adalah mutasi yang didasarkan atas landasan kekeluargaan. Sistem mutasi seperti ini kurang baik karena didasarkan atas pertimbangan suka atau tidak suka (like or dislike).

\section{Jenis-Jenis Mutasi}

Jenis mutasi menurut Endang (2010:87) adalah

a. Ditinjau dari tempat kerja karyawan

1) Mutasi antarurusan

2) Mutasi antarseksi

3) Mutasi antarbagian 
4) Mutasi antarbiro

5) Mutasi antarinstansi

b. Ditinjau dari masa kerja karyawan

1) Temporary transfer, mutasi yang bersifat sementara untuk mengganti karyawan yang cuti atau berhalangan

2) Permanent transfer, mutasi yang bersifat tetap

3) Production transfer, mutasi pada jabatan yang sama, karena produksi ditempat yang lama menurun

4) Replacement transfer, mutasi dari jabatan yang sudah lama dipagang ke jabatan yang sama dibagian lain, untuk menggantikan karyawan yang belum lama bekerja/diberhentika

5) Versatility transfer, mutasi dari jabatan yang satu ke jabatan yang lain untuk menambah pengetahuan karyawan yang bersangkutan

6) Shift transfer, mutasi dalam jabatan yang sama. Misalnya shift A (Malam) pindah ke shift B (pagi)

7) Remedial transfer, mutasi karyawan ke bagian mana saja untuk memupuk dan memperbaiki kerja sama antarkaryawan

\section{Sebab-sebab dan alasan Mutasi}

Sebab-sebab pelaksanaan mutasi menurut Siswandi (1999) digolongkan sebagai berikut :

a. Permintaan sendiri

Mutasi atas permintaan sendiri adalah mutasi yang dilakukan atasa keinginan sendiri dari karywan yang bersangkutan dan dengan mendapat persetujuan pimpinan organisasi. Mutasi pemintaan sendiri pada umumnya hanya pemindahan jabatan yang peringkatnya sama baik, anatrbagian maupun pindah ke tempat lain.

b. Alih tugas produktif (ATP)

Alih tugas produktif adalah mutasi karena kehendak pimpinanan perusahaan untuk meningkatkan produksi dengan menempatkan karywan yang bersangkutan ke jabatan atau pekerjannya yang sesuai dengan kecakapannya.

\section{Kendala-kendala pelaksanaan mutasi}

a. Formasi jabatan tidak (belum) memungkinkan 

b. Pengaruh senioritas
c. Soal etis (etika)
d. Kesulitan menetapkan standar-standar sebagai kriteria untuk pelaksanaan

8. Cara mutasi dalam organisasi, menurut Hasibuan (2011:103)

a. Cara tidak ilmiah

1) Tidak didasarkan pada norma/standar kriteria tertentu

2) Berorientasi semata-mata kepada masa kerja dan ijazah, bukan atas prestasi atau faktor-faktor riil

3) Berorientasi pada banyaknya anggaran yang tersedia, bukan atas kebutuhan riil karyawan

4) Berdasarkan spoil system

5) Berdasarkan norma atau standar kriteria tertentu, seperti analis pekerjaan

6) Berorientasi pada kebutuhan yang riil/nyata

7) Berorientasi pada formasiriil kepegawaian

8) Berorientasi pada tujuan yang beraneka ragam

9) Berdasarkan objektifitas yang dapat dipertanggungjawabkan

9. Hal-hal yang harus diperhatikan dalam mutasi, Manullang (2008:276)

a. Jabatan karyawan yang dipindahkan harus bersamaan isinya dengan jabatan yang ditinggalkan

b. Metode melakukan pekerjaan harus sama antara yang satu dengan yang lain

c. Pejabat yang dimutasikan harus mempunyai pengalaman yang memungkinkan mengerti dasar-dasar pekerjaan baru

10. Beberapa tips yang perlu dilakukan oleh organisasi yang dalam hal ini divisi/departemen atau direktorat dalam melaksanakan proses mutasi dan atau rotasi di kalangan karyawannya:

a. Yang penting baik mutasi maupun rotasi, keduanya harus merupakan bagian integral dari sistem keorganisasian. Harus didasarkan pada perencanaan strategis, kriteria dan indikator yang terukur, dan prospektif pada pengembangan SDM serta karir. Karena itu sebelum perusahaan melakukan proses mutasi dan rotasi maka diperlukan pemetaan potensi, performa dan 
perilaku karyawan di semua unit. Dalam pelaksanaannya harus menggunakan prosedur operasi standar.

b. Perlu tidaknya ada mutasi dan rotasi dengan segala persyaratannya merupakan kebijakan pimpinan puncak organisasi setelah melalui rapat-rapat pimpinan dan rapat di lini terbawah. Namun demikian siapa-siapa yang terkena mutasi dan rotasi sebaiknya diusulkan oleh pimpinan unit divisi kepada pimpinan puncak setelah ada usul dari setiap manajer. Karena manajerlah yang paling tahu perkembangan karyawannya dan kondisi unitnya. Direktorat atau depertemen atau divisi SDM hanyalah pelaksana kebijakan pimpinan puncak organisasi; dengan kata lain tidak terlibat praktis dan langsung menentukan orang-orang atau jabatan yang dimutasi dan dirotasi.

c. Mutasi dan rotasi janganlah terlalu didasarkan pada pragmatisme seperti demi penyegaran karyawan. Kalau seperti itu tidak perlu dilakukan mutasi dan rotasi besar-besaran. Asalkan pihak manajer selalu mengembangkan suasana belajar dan hubungan kemitraan kerja sesama karyawan dan atasan yang efektif maka kejenuhan tidak akan terjadi atau kalau toh ada tetapi relatif kecil.

d. Proses memutuskan perlunya mutasi dan atau rotasi karyawan untuk seluruh unit yang memiliki lingkup dan beban kerja yang sama jangan main pukul rata. Lho kok begitu? Karena kinerja masing-masing unit, potensi SDM, dan lingkungan kerjanya cenderung beragam. Kalau pendekatannya dengan asumsi semua konsidi unit seragam akan menimbulkan kontra produktif. Jadi prioritas adanya mutasi dan rotasi hendaknya pimpinan unit yang kinerjanya cenderung di bawah atau rata-rata organisasi. Atau bisa dilakukan mutasi kalau ada karyawan yang memang sudah tepat memeroleh promosi dalam rangka kenaikkan jenjang karir. Atau mutasi dilakukan dalam rangka demosi karyawan.

e. Setelah melakukan persiapan yang matang dan semua pimpinan unit bersetuju barulah dilakukan sosialisasi kepada seluruh karyawan yang akan mutasi dan rotasi. Sejauh mungkin dilakukan pelatihan atau penyegaran yang intinya adalah bagaimana melakukan orientasi kerja pada lingkungan kerja baru, pengembangan dinamika kelompok, dan tentang budaya kerja.

Employee transfer dilakukan apabila karyawan promosi, demosi, mutasi, rotasi, ataupun pergantian status kepegawaian (probation, kontrak, permanen). Data 
tersebut harus dilakukan melalui menu "Employee Transfer" agar dapat ditentukan effective date perubahan serta tercatat sejarahnya pada sistem di bagian History karyawan.

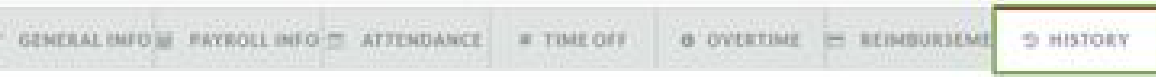

BARI's history

Musia year enolone Niation

ADovisecoct vesroay

TRANSFLR Hestok

conw wiston:

nop iestow

\section{Transfer History}

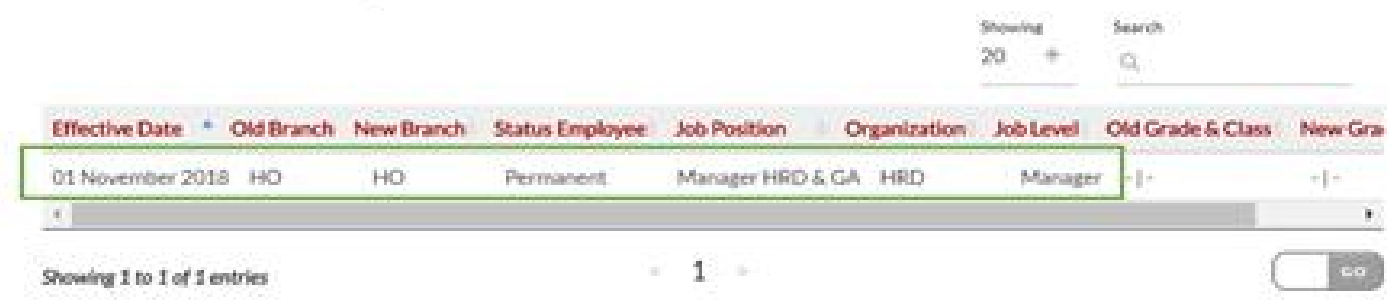

Gambar 9.1 Aplikasi transfer karyawan

\section{F. Sub Materi 6: Pemberhentian Kerja / PHK / Putus Hubungan Kerja / Pemecatan}

Putus hubungan kerja adalah pemberhentian atau dikeluarkannya seorang karyawan atau pegawai dari lingkungan organisasi baik dengan atas inisiatif pribadi sendiri maupun secara paksa atas prakasra perusahaan tempatnya bekerja. Pemberhentian sukarela biasanya berbentuk pengunduran diri atau pensiun, sedangkan yang secara paksa bentuknya seperti pemberhentian sementara waktu atau permanen alias dipecat / pemecatan.

Pensiun bisa berupa pensiun reguler di mana seorang karyawan telah mencapai usia atau umur tertentu secara wajar dan mungkin mengalami penurunan kinerja. Sedangkan pensiun dini atau pensiun diperceat adalah pensiun yang dilakukan untuk melakukan restrukturisasi pada organisasi dengan memberikan status pensiun pada karyawan yang seharusnya belum layak pensiun. 
Pecat atau pemecatan pada umumnya dihindari oleh perusahaan karena memiliki biaya yang cukup besar pada jangka panjang untuk membayar pesangon, gaji, asuransi, beban psikologis dan lain sebagainya.

\section{G. Sub Materi 7: Job Rotation (Perputaran Jabatan)}

1. Mutasi tempat : Perpindahan daerah/lokasi kerja tapi masih pada jabatan yang tingkat/level yang sama

2. Mutasi Jabatan: Pemindahan seseorang tenaga kerja dari suatu jabatan ke jabatan lain pada level/tingkat dan lokasi yang sama

3. Rehabilitasi: Kebijaksanaan organisasi untuk menempatkan kembali seorang tenaga kerja pada posisi terdahulu

4. Produstion transfer: Bentuk rotasi horizontal yang ditujukan untuk mengisi kekosongan pekerja oada bidang tertentu

5. Replacement transfer: Pergantian tenaga kerja dalam organisasi untuk mepertahankan yang berpengalaman

6. Verselity transfer: Bentuk mutasi horizontal untuk menenpatkan tenaga kerja yang memiliki keahlian tertentu di jabatan tertentu

7. Personnel transfer: Mutasi horizontal yang terjadi atas kehendak/keinginan tenaga kerja bersangkutan

\section{H. Sub Materi 8: Kepuasan Kerja}

Sesuatu yang bersifat individual, setiap individu memiliki tingkat kepuasan yang berbeda-beda sesuai dengan sistem nilai yang berlaku pada dirinya. Semakin tinggi nilai penilan terhadap kegiatan dirasakan sesuai dengan keinginan individu, maka makin tinggi kepuasannya terhadap kegiatan tersebut. Kepuasan kerja mempengaruhi tingkat kedisiplinan karyawan, artinya jika kepuasan diperoleh dari pekerjaan maka kedisiplinan karyawan baik. Sebaliknya jika kepuasan kerja kurang tercapai dipekerjaannya maka kedisiplinan karyawan rendah.

1. Faktor yang mempengaruhi kepuasan kerja

a. Faktor psikologik

Meliputi minat, bakat, ketentraman dalam bekerja, dan sikap terhadap pekerjaan

b. Faktor sosial 
Berhubungan dengan interaksi sosial atar sesama pekerja, pekerja dengan atasan, maupun masyarakat

c. Faktor fisik

Berhubungan dengan kodisi fisik lingkungan kerja seperti jenis kerja, keadaan ruangan, pengaturan waktu kerja dan istirahat, perlengkapan kerja dan peralatan keselamatan kerja

d. Faktor finansial

Meliputi besarnya upah dan sistem penggajian, jaminan sosial, macam-macam tunjangan dan fasilitas yang diberikan 


\section{MATERI X}

\section{Penilaian Prestasi Kerja SDM}

\section{A. Sub Materi 1: Prestasi Kerja}

Prestasi kerja adalah hasil kerja secara kualitas dan kuantitas yang dicapai oleh seseorang pegawai dalam melaksanakan tugasnya sesuai dengan tanggung jawab yang diberikan kepadanya (Mangkunegara, 2009:67). Selanjutnya (Handoko, 2007:135) mengatakan bahwa prestasi kerja adalah suatu hasil kerja yang dicapai organisasi mengevaluasi atau menilai karyawannya.

Berdasarkan beberapa pendapat di atas, dapat disimpulkan bahwa prestasi kerja pegawai merupakan hasil yang dicapai pegawai dalam pelaksanaan suatu pekerjaan yang diberikan kepadanya baik secara kuantitas maupun kualitas melalui prosedur yang berfokus pada tujuan yang hendak dicapai serta dengan terpenuhinya standard pelaksanaan.

\section{B. Sub Materi 2: Penilaian Prestasi Kerja}

Menurut Mathis dalam Zainal (2014:406)

Menyatakan penilaian kerja (performance appraisal) adalah proses mengevaluasi seberapa baik karyawan melakukan pekerjaan mereka jika dibandingkan dengan seperangkat standar, dan kemudian mengomunikasikan informasi tersebut pada karyawan.

Martoyo (2007:89)

Menjelaskan bahwa setiap penilaian prestasi kerja karyawan harus benar-benar memiliki tujuan yang jelas apa yang ingin dicapai.

\section{Jenis-Jenis Penilaian Prestasi Kerja}

a. Penilaian hanya oleh atasan

1). Cepat dan langsung.

2). Dapat mengarah ke distorsi karena pertimbangan-pertimbangan pribadi.

b. Penilaian oleh kelompok lini: atasan dan atasannya lagi bersama-sama membahas kinerja dari bawahannya yang dinilai.

1) Objektivitasnya lebih akurat dibandingkan kalau hanya oleh atasan sendiri. 
2) Individu yang dinilai tinggi dapat mendominasi penilaian

c. Penilaian oleh kelompok staf: atasan meminta satu atau ebih individu untuk bermusyawarah dengannya; atasan langsung yang membuat keputusan akhir.

d. Penilaian gabungan yang masuk akal dan wajar.

e. Penilaian melalui keputusan komite: sama seperti pada pola sebelumnya kecuali bahwa manajer yang bertanggung jawab tidak lagi mengambil keputusan akhir; hasilnya didasarkan pada pilihan mayoritas.

1) Memperluas pertimbangan yang ekstrim.

2) Memperlemah integritas manajer yang bertanggung jawab.

f. Penilaian berdasarkan peninjauan lapangan: sama seperti pada kelompok staf, namun melibatkan wakil dari pimpinan pengembangan atau departemen SDM yang bertindak sebagai peninjau yang independen. Membawa satu pikiran yang tetap ke dalam satu penilaian lintas sektor yang besar.

g. Penilaian oleh bawahan dan sejawat.

1). Mungkin terlalu subjektif.

2). Mungkin digunakan sebagai tambahan pada metode penilaian yang lain.

\section{Tujuan Penilaian Prestasi Kerja}

a. Untuk mengetahui tingkat prestasi karyawan selama ini.

b. Pemberian imbalan yang serasi, misalnya untuk pemberian kenaikan gaji berkala, gaji pokok, kenaikan gaji istimewa, insentif uang.

c. Mendorong pertanggung jawaban dari karyawan.

d. Untuk pembeda antar karyawan yang satu dengan yang lain.

e. Pengembangan SDM yang masih dapat dibedakan lagi ke dalam:

1).Penugasan kembali, seperti diadakannya mutasi atau transfer, rotasi pekerjaan.

2) Promosi, kenaikan jabatan.

3) Training atau latihan

4) Meningkatan motivasi kerja

5) Meningkatan etos kerja

6) Memperkuat hubungan antara karyawan dengan supervisor melalui diskusi tentang kemajuan kerja mereka. 
7) Sebagai alat untuk memperoleh umpan balik dari karyawan untuk memperbaiki desain pekerjaan, lingkungan kerja, dan rencana karier selanjutnya.

8) Riset seleksi sebagai kriteria keberhasilan/efektivitas.

9) Sebagai salah satu sumber informasi untuk perencanaan SDM, karier dan keputusan perencanaan suksesi.

10) Membantu menempatakan karyawan dengan pekerjaan yang sesuai untuk mencapai hasil yang baik secara menyeluruh.

11) Sebagai sumber informasi untuk pengambilan keputusan yang berkaitan dengan gaji-upah-insentif-kompensasi dan berbagai imbalan lainnya.

12) Sebagai penyaluran keluhan yang berkaitan dengan masalah pribadi maupun pekerjaan.

13) Sebagai alat untuk menjaga tingkat kinerja.

14) Sebagai alat untuk membantu dan mendorong karyawan untuk mengambil inisiatif dalam rangka memperbaiki kinerja.

15) Untuk mengetahui efektivitas kebijakan SDM, seperti seleksi, rekrutmen, pelatihan dan analisis pekerjaan sebagai komponen yang saling ketergantungan di antara fungsi-fungsi SDM.

16) Mengidentifikasi dan menghilangkan hambatan-hambatan agar kinerja menjadi baik.

17) Mengembangkan dan menetapkan kompensasi pekerjaan.

18) Pemutusan hubungan kerja, pemberian sanksi ataupun hadiah.

\section{Manfaat Penilaian Prestasi Kerja}

Menurut Sedarmayanti (2010:264) menyatakan bahwa penilaian kerja meliputi:

a. Meningkatkan prerstasi kerja

b. Dengan adanya penilaian, baik pimpinan maupun karyawan memperoleh umpan balik dan mereka dapat memperbaiki pekerjaan/prestasinya.

c. Memberi kesempatan kerja yang adil

d. Penilaian yang akurat dapat menjamin karyawan dalam memperoleh kesempatan menempati pekerjaan sesuai kemampuannya.

e. Kebutuhan pelatihan dan pengembangan. 
f. Melalui penilaian kinerja, terdeteksi karyawan yang kemapuannya rendah sehingga memungkinkan adanya program pelatihan untuk meningkatkan kemampuan mereka.

Menurut Sedarmayanti (2010:264) menyatakan bahwa penilaian kerja meliputi:

a. Penyesuaian kompensasi melalui penilaian, pimpinan dapat mengambil keputusan dalam menentukan pemberian kompensasi, dan sebagainya.

b. Keputusan promosi dan demosi

c. Hasil penilaian kinerja dapat dipergunakan sebagai dasar pengambilanya keputusan untuk memperomosikan atau mendemosikan karyawan.

d. Mendiagnosa kesalahan desain pekerjaan.

e. Kinerja yang buruk mungkin merupakan suatu tanda kesalahan dalam desain pekerjaan. Penilaian kerja dapat membantu mendiagnosis kesalahan tersebut.

\section{Faktor-faktor Penilaian Prestasi Kerja Karyawan}

Menurut Byars, et al. dalam Sutrisno (2015:151) mengemukakan ada dua faktor yang memengaruhi prestasi kerja, yaitu faktor individu dan faktor lingkungan.

Faktor-faktor individu yang dimaksud adalah:

a. Usaha (effort) yang menunjukkan sejumlah sinergi fisik dan mental yang digunakan dalam menyelenggarakan gerakan tugas.

b. Abilities, yaitu sifat-sifat personal yang diperlukan untuk melaksanakan suatu tugas.

c. Persepsi tugas, yaitu segala perilaku dan aktivitas yang dirasa perlu oleh individu untuk menyelesaikan suatu pekerjan.

\section{Faktor-faktor Penilaian Prestasi Kerja Karyawan}

Adapun faktor - faktor lingkungan yang mempengaruhi prestasi kerja adalah :

a. Kondisi fisik

b. Peralatan

c. Waktu

d. Material

e. Pendidikan

f. Supervisi

g. Desain organisasi 
h. Pelatihan

i. Keberuntungan

6. Faktor - faktor yang Mempengaruhi Prestasi Kerja

Menurut Steers dalam Sutrisno Edy (2014 : 151), umumnya orang percaya bahwa prestasi kerja individu merupakan fungsi gabungan dari tiga faktor, yaitu :

a. Kemampuan, perangai dan minat seorang pekerja

b. Kejelasan dan penerimaan atas penjelasan peranan seorang pekerja

c. Tingkat motivasi kerja

\section{Faktor Penghambat Penilaian Kinerja}

Bias adalah distorsi pegukuran yang tidak akurat. Bias ini mungkin terjadi sebagai akibat ukuran-ukuran yang digunakan bersifat subjektif. Berbagai bentuk bias yang umum terjadi menurut Zainal (2014:412) adalah sebagai berikut:

a. Kendala hukum/legal

Penilaian kinerja harus bebas dari diskriminsi tidak sah atau tidak legal. Apapun format penilaian kinerja yang digunakan oleh departemen SDM harus dan dapat dipercaya. Jika hal tersebut tidak dipenuhi, keputusan penempatan mungkin ditentang sebab melanggar hukum ketenagakerjaan atau hukum lainnya.

b. Bias oleh Penilai (Penyelia)

Bentuk-bentuk bias umumnya yang terjadi adalah:

1). Hallo effect. Terjadi ketika pendapat pribadi penilai (penyelia) memengaruhi pengukuran kinerja baik dalam arti positif maupun negatif.

2). Kesalahan kecenderungan terpusat. yang dinilai sangat positif atau sangat negatif.

3). Bias karena terlalu lunak dan terlalu keras.

4) Bias karena penyimpangan lintas budaya.

5). Bias karena penyimpangan lintas budaya.

6) Pengaruh kesan terakhir.

c. Mengurangi bias penilai

Pelatihan untuk penilai perlu melibatkan tiga hal berikut:

1). Penyimpangan dan penyebab mereka harus diterangkan.

2). Peran penilaian kinerja dalam pengambilan keputusan terhadap karyawan harus diterangkan untuk menjaga kenetralan dan objektivitas. 
3). Dengan bantuan departemen SDM menemukan dan menggunakan teknik penilaian yang dipandang paling tepat, baik yang berorientasi pada prestai kerja di masa lalu maupun yang ditujukan kepada kepentingan perusahaan di masa depan.

\section{Hal-hal yang diperlukan dalam penilaian kinerja}

a. Standar kinerja

Sistem penilaian memerlukan standar kinerja yang mencerminkan seberapa jauh keberhasilan sebuah pekerjaan telah tercapai.

b. Ukuran Kinerja

Evaluasi kinerja juga memerlukan ukuran/standar kinerja yang dapat diandalkan yang digunakan untuk mengevaluasi kinerja.

\section{Metode Penilaian Prestasi Kerja}

Menurut Sunyoto (2012:202) mengatakan bahwa dalam penilaian prestasi kerja ada macam-macam metodenya, antara lain:

\section{a. Rating Scale}

Penilaian prestasi kerja terhadap pegawai berdasarkan sifat-sifat dan karakteristik dari macam pekerjaan dan menentukan parameternya.

\section{b. Checklist}

Penilaian yang dilakukan untuk mengurangi beban dinilai, dengan diminta laporan secara singkat mengenai perilaku yang berhubungan dengan pekerjaan pegawai.

c. Field review method.

Penilaian prestasi kerja pegawai untuk mencapai penilai yang lebih standar. Dalam hal ini wakil ahli dari departemen personalia turun kelapangan membantu penilai dalam penilaian.

d. Tes dan observasi prestasi kerja.

Hal ini dimaksudkan untuk menguji keterampilan-keterampilan pegawai dan pengetahuan yang perlu dimiliki seorang pegawai dalam menjalankan tugasnya.

e. Metode evaluasi kelompok.

Penilaian prestasi kerja dengan tujuan untuk mengevaluasi pengetahuan pegawai dan kemampuan-kemampuan pegawai dan kemampuankemampuan pegawai dalam berbagai macam pekerjaan guna pengambilan keputusan. 
10. Syarat penilaian prestasi kerja (Zainal, 2014:414)

a. Praktis. Keterkaitan langsung dengan pekerjaan seseorang adalah bahwa penilaian ditujukan pada perilaku dan sikap yang menentukan keberhasilan menyelesaikan suatu pekerjaan tertentu.

b. Kejelasan standar. Standar adalah merupakan tolok ukur seorang dalam melaksankanan pekerjaanya.

c. Kriteria yang objektif. Kriteria yang dimaksud adalah berupa ukuranukuran yang memenuhi persyaratan seperti mudah digunakan, handal, dan memberikan informasi tentang perilaku kritikal yang menentukan keberhasilan dalam melaksanakan pekerjaan.

\section{Syarat Evaluasi Kinerja}

a. Formal, berdasarkan serangkaian kriteria.

b. Rasional

c. Obyektif

d. Didokumentasikan secara sistematik.

12. Tiga kelemahan dalam syarat Evaluasi Kinerja

a. Tanpa kriteria yang relatif seragam, Gaya penilaian akan sangat beragam, interpretasi yang berbeda-beda.

b. Tidak ada jaminan bahwa atasan penilai mendasarkan penilaiannya pada kriteria yang obyektif.

c. Hasil penilaian sangat $m$ ungkin tidak terdokumentasikan dengan baik, padahal hasil penilaian tsb harus merupakan bagian dari dokumen kepegawaian karyawan yang dinilai.

13. Evaluasi kinerja melibatkan tiga pihak:

a.. Bagian kepegawaian/personalia

b.. Atasan langsung

c. Pegawai yang dinilai.

\section{Indikator Penilaian Prestasi Kerja}

Menurut Siswanto dalam Simanjuntak (2015:24) adalah:

a. Kesetiaan yaitu tekad dan kesanggupan 

b. Tanggung jawab
c. Ketaatan
d. Kejujuran
e. Kerjasama
f. Prakarsa yaitu kemampuan seorang tenaga kerja untuk mengambil keputusan
g. Kepemimpinan
h. Kualitas kerja

\section{Pengukuran prestasi kerja}

Terdapat enam aspek yang merupakan bidang prestasi kunci bagi perusahaan yang bersangkutan.
a. Hasil Kerja
b. Pengetahuan pekerjaan
c. Inisiatif
d. Kecakapan mental
e. Sikap
f. Disiplin waktu dan absensi

16. Keberhasilan kerja atau prestasi kerja

a. Harus dilihat aspek - aspek yang menyangkut kriteria pengukuran keberhasilan kerja yang merupakan sasaran akhir dari pelaksanaan suatu pekerjaan.

b. Perilaku dari individu itu sendiri dalam usahanya untuk mencapai keberhasilan sesuai dengan standar yang telah ditetapkan. Perilaku itu sendiri dipengaruhi oleh dua variabel utama yang individual dan situasional.

\section{Sub Materi 3: Hubungan kepuasan kerja dengan prestasi kerja}

Gibson, Ivancevich dan Donelly dalam Wibowo (2016:420),

Secara jelas menggambarkan "adanya hubungan timbal balik antara kinerja dan kepuasan kerja. Kepuasan kerja menyebabkan peningkatan kinerja sehingga pekerja yang puas akan lebih produktif, di sisi lain dapat pula terjadi kepuasan kerja disebabkan oleh adanya kinerja atau prestasi kerja sehingga pekerjaan yang lebih produktif akan mendapatkan kepuasan.” 
1. Hubungan komunikasi dengan prestasi kerja

Menurut Fahmi Irham (2016: 190),

Organisasi diciptakan melalui komunikasi. Komunikasi tidak sekedar instrumen atau alat untuk berinteraksi tetapi komunikasi adalah medium yang menyebabkan adanya organisasi. Komunikasi yang dilakukan antara individu dan kelompok dalam organisasi merupakan bagian penting dari proses organisasi yang berlangsung terus menerus

\section{Hubungan disiplin kerja dengan prestasi kerja}

Menurut Fathoni Abdurrahmat (2009 : 172),

"Kedisiplinan harus ditegakkan dalam suatu organisasi perusahaan, karena tanpa dukungan disiplin karyawwan yang baik, maka sulit bagi perusahaan untuk mewujudkan tujuannya. Jadi, kedisiplinan adalah kunci keberhasilan suatu perusahaaan mencapai tujuan.”

\section{Evaluasi Kinerja}

Evaluasi kinerja merupakan pendapat yang bersifat evaluatif atas sifat, perilaku seseorang, atau prestasi sebagai dasar untuk keputusan dan rencana pengembangan personel (Kreitner dan Kinicki dalam Wibowo, 2014).

4. Newstrom dan Davis dalam Wibowo memandang sebagai suatu proses mengevaluasi kinerja pekerja, membagi informasi dengan mereka, dan mencari cara memperbaiki kinerjanya. Evaluasi mengidentifikasi kebutuhan pelatihan dan pengembangan. Evaluasi menunjukkan keterampilan dan kompetisi pekerja yang ada sekarang ini kurang cukup sehingga dikembangkan program. Efektivitas pelatihan dan pengembangan dipertimbangkan dengan mengukur seberapa baik pekerja yang berpartisipasi mengerjakan evaluasi kinerja.

\section{Pendekatan sikap}

Pendekatan ini menyangkut penilaian terhadap sifat atau karakteristik individu. Sifat biasanya diukur dalam bentuk inisiatif, kecepatan membuat keputusan, dan ketergantungan. Meskipun pendekatan sifat sangat luas dipergunakan oleh manajer, pada umumnya dipertimbangkan oleh para ahli sebagai paling lemah. 


\section{Pendekatan Perilaku}

Masalah dalam pendekatan perilaku menunjukkan bagaimana orang berperilaku, dan bukan tentang kepribadiannya. Kemampuan orang untuk bertahan meningkat apabila penilaian kinerja didukung oleh tingkat perilaku kinerja.

\section{Pendekatan hasil}

Apabila pendekatan sikap memfokuskan pada proses, pendekatan hasil memfokus pada produk atau hasil usaha seseorang.

\section{Pendekatan Kontingensi}

Pendekatan sifat, perilaku, dan hasil cocok untuk dipergunakan tergantung pada situasi tertentu. Oleh karena itu, diusulkan pendekatan kontingensi yang selalu dicocokan dengan situasi tertentu yang sedang berkembang.

\section{Sasaran Evaluasi}

Menurut Kreitner dan Kinicki dalam Wibowo (2014), evaluasi kinerja dapat dipergunakan untuk:
a. Administrasi Penggajian;
b. Umpan balik kinerja;
c. Identifikasi kekuatan dan kelemahan individu;
d. Mendokumentasikan keputusan kepegawaian;
e, Penghargaan terhadap kinerja individu;
f. Mengidentifikasi kinerja buruk;
g. Membantu dalam mengidentifikasi tujuan;
h. Menetapkan keputusan promosi;
i. Pemberhentian pegawai;dan
j. Mengevaluasi pencapaian tujuan.

10. Evaluasi kinerja dapat dipergunakan untuk kepentingan yang lebih luas lagi, seperti:

a. Evaluasi Tujuan dan sasaran;

Evaluasi terhadap tujuan dimaksudkan untuk mengetahui apakah tujuan yang telah ditetapkan sebelumnya dapat tercapai atau tidak. 


\section{b. Evaluasi Rencana}

Evaluasi kinerja melakukan penilaian apakah hasil yang dicapai sesuai dengan apa yang direncanakan. Apabila hasil yang diperoleh tidak seperti yang diharapkan dalam rencana, dicari tahu apa yang menyebabkan.

c. Evaluasi Lingkungan

Evaluasi kinerja melakukan penilaian apakah kondisi lingkungan yang dihadapi pada waktu proses pelaksanaan tidak seperti yang diharapkan, tidak kondusif, dan mengakibatkan kesulitan atau kegagalan dalam mencapai hasil kinerja.

d. Evaluasi Proses Kinerja

Evaluasi kinerja melakukan penilaian apakah terdapat kendala dalam proses pelaksanaan kinerja. Apakah mekanisme kerja dapat berjalan seperti yang diharapkan? Apakah terdapat masalah kepemimpinan dan hubungan antar manusia dalam organisasi?

e. Evaluasi Pengukuran Kinerja

Evaluasi kinerja menilai pakah penilaian kinerja telah dilakukan dengan benar, apakah sistem review dan coaching telah berjalan dengan benar serta apakah metode yang dipergunakan dalam pengukuran kinerja sudah tepat dan dilakukan dengan benar oleh seorang penilai yang objektif.

f. Evaluasi Hasil

Evaluasi terhadap hasil kinerja dapat dilakukan terhadap hasil kinerja organisasi, kelompok maupun individu masing-masing pekerja. Evaluasi terhadap terhadap hasil kinerja organisasi dapat diketahui dari seberapa besar tujuan dan sasaran organisasi telah dapat dicapai.

\section{Metode Evaluasi}

Metode yang dapat dipergunakan dalam melakukan evaluasi kinerja pada dasarnya sama dengan metode yang dipergunakan dalam mendapatkan umpan balik, melakukan penilaian dan review.

Pandangan Vecchio, Robbins, Kreitner, dan Kinicki dalam Wibowo pada dasarnya sama dan bersifat saling melengkapi. Metode yang dapat dipergunakan adalah:

a. Penilaian diri sendiri dari pekerja bersangkutan;

b. Penilaian dari atasan langsung;

c. Penilaian dari rekan sekerja;

d. Penilaian dari bawahan langsung; 
e. Penilaian dari sumber lain seperti pelanggan, pemasok, komite para manajer, konsultan eksternal; dan

f. Evaluasi 360 derajat.

12. Metode Evaluasi

a. Memperbaiki Evaluasi Kinerja

Proses evaluasi kinerja potensial menimbulkan masalah. Evaluator dapat melakukan tindakan bermurah hati, efek halo dan kesalahan semacamnya atau menggunakan proses untuk tujuan politis.

b. Menekankan pada perilaku daripada sikap

Banyak sifat yang sering dipertimbangkan mempunyai hubungan dengan kinerja baik, kenyataannya tidak mempunyai atau sedikit sekali hubungannya dengan kinerja. Sifat seperti loyalitas, inisiatif, keberanian, dapat dipercaya dan ekspresi diri secara intiutif menarik sebagai karateristik pekerja.

c. Mencatat perilaku kinerja dalam buku harian

Buku harian membantu evaluator mengelola informasi lebih baik dalam memorinya. Kenyataan mengindikasikan bahwa dengan menjaga buku harian khususu setiap kejadian kritis setiap pekerja, evaluasi cendrung lebih akuratdan kurang melakukan kesalahan dalam menetapkan penilaian.

d. Menggunakan banyak evaluator

Dikarenakan jumlah evaluator bertambah banyak, kemungkinan mengusahakan informasi yang lebih akurat meningkat.

e. Mengevaluasi secara efektif

Penilai seharusnya hanya mengevaluasi di bidang dimana mereka mempunyai keahlian. Apabila penilai melakukan evaluasi hanya pada dimensi dimana mereka pada posisi baik untuk menilai, kita meningkatkan interater agreement dan membuat evaluasi sebagai proses yang lebih valid.

f. Melatih evaluator

Apabila tidak dapat menemukan evaluator yang baik, alternatifnya adalah membuat evaluator yang baik. Kenyataan menunjukkan bahwa melatijh evaluator secara substansial membuat mereka menjadi penilai yang akurat.

g. Menyediakan pekerja dengan proses perlindungan.

Konsep proses perlindungan dapat diterapkan pada penilaian untuk meningkatkan persepsi bahwa pekerja diperlakukan dengan adil. 
13. Teknik Evaluasi Individu

a. Written Essays

Teknik ini memberikan evaluasi kinerja dengan cara mendeskripsikan apa yang menjadi penilaian terhadap kinerja individu, tim maupun organisasi.

b. Critical Incidents

Teknik ini mengevaluasi perilaku yang menjadi kunci dalam membuat perbedaan antara menjalankan pekerjaan secara efektif dengan tidak efektif.

c. Graphic Rating Scales

Teknik ini merupakan metode evaluasi dimana evaluator meningkatkan faktor kinerja dalam skala inkremental.

d. Behaviorally Anchored Rating Scales

Teknik ini merupakan pendekatan skala yang mengkombinasikan elemen utama dari critical incident dan graphic rating scale.

e. Group Order Ranking

Teknik ini merupakan metode evaluasi yang menempatkan pekerja ke dalam klasifikasi tertentu, seperti quartiles.

\section{f. Individual Ranking}

Teknik ini merupakan suatu metode evaluasi yang menyusun/rankorder pekerja dari terbaik ke terburuk.

g. Paired Comparison

Teknik ini merupakan metode evaluasi yang membandingkan masing-masing pekerja dengan setiap pekerja lain dan menyusun peringkat berdasarkan pada jumlah nilai superior yang dicapai pekerja.

\section{Evaluasi Kinerja Tim}

Konsep evaluasi kinerja hampir dikembangkan hanya dengan pekerja individu dalam pikiran. Hal tersebut mencerminkan kepercayaan bahwa individu merupakan bangunan utama yang dibangun di sekitar organisasi. Namun, semakin banyak organisasi yang membangun tim, bagaimana mereka harus mengevaluasi kinerja.

\section{Saran Menyusun Rancangan Evaluasi Kinerja Tim}

a. Mengikat hasil tim pada tujuan organisasi. Untuk itu, penting menemukan ukuran yang diterapkan pada tujuan penting yang diharapkan dapat diselesaikan tim. 
b. Memulai dengan pelanggan tim dan proses kerja yang diikuti tim untuk melmuaskan kebutuhan pelanggan. Produk akhir yang diterima pelanggan dapat dievaluasi dalam bentuk persyaratan pelanggan.

c. Mengukur kinerja tim dan individu. Untuk itu, didefinisikan peran setiap anggota tim dalam bentuk penyelesaian yang mendukung proses kerja tim. Kemudian, mengukur kontribusi masing-masing anggotadan kinerja menyeluruh tim.

d. Melatih tim untuk menciptakan ukuran sendiri. Tim mendefinisikan sasarannya dan setiap anggota memastikan bahwa setiap orang memahami perannya dalam tim dan membantu mengembangkan ke dalam unit yang lebih berat. 


\section{MATERI XI}

\section{Kompensasi, Keamanan dan Kesehatan SDM}

\section{A. Sub Materi 1: Kompensasi}

1. Pengertian Kompensasi

Karyawan yang bekerja dalam sebuah organisasi pasti membutuhkan kompensasi atau imbalan yang cukup dan adil, malah kalau bisa cukup kompetitif di banding dengan organisasi atau perusahaan lain. Sistem kompensasi yang baik akan sangat mempengaruhi semangat kerja dan produktivitas dari seseorang. Suatu sistem kompensasi yang baik perlu didukung oleh metode secara rasional yang dapat menciptakan seseorang digaji atau diberi kompensasi sesuai tuntunan pekerjaannya

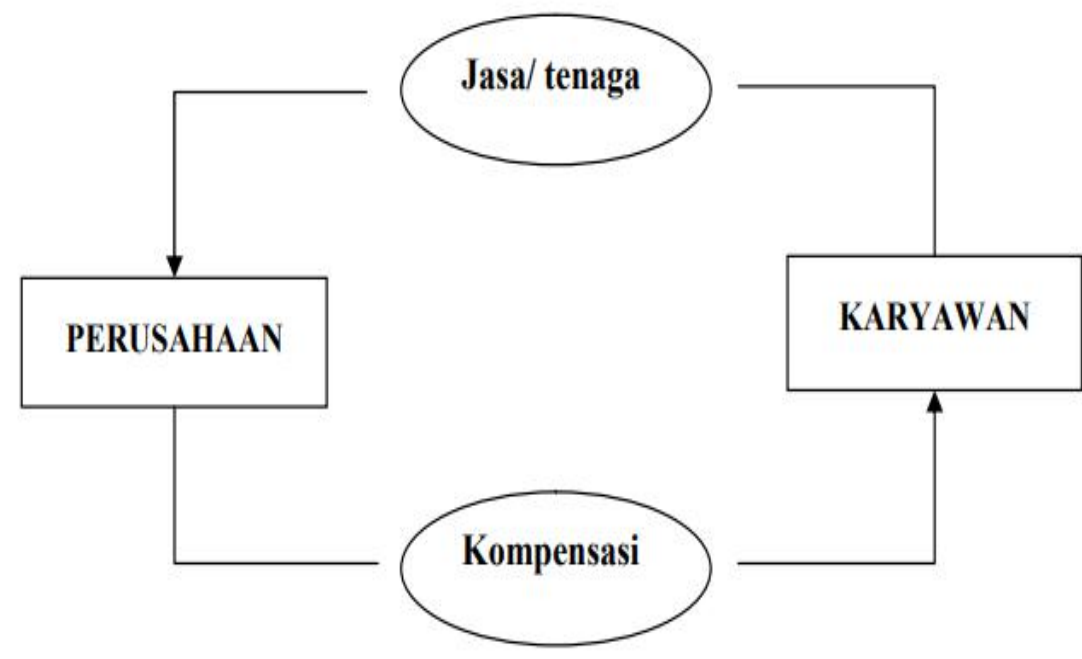

Gambar 11.1. Umpan balik jasa atau tenaga dan kompensasi (Jahrie dan Hariyoto, 1999:109)

2. Fungsi Kompensasi

Fungsi Kompensasi

Menurut Martoyo (1994), fungsi kompensasi adalah :

a. Penggunaan SDM secara lebih efisien dan lebih efektif

b. Mendorong stabilitas dan pertumbuhan ekonomi

\section{Jenis Kompensasi}

Jenis-jenis kompensasi selain upah/gaji tetap adalah 
a. Pengupahan insentif;

Insentif adalah memberikan upah/gaji berdasarkan perbedaan prestasi kerja sehingga bisa jadi dua orang yang memiliki jabatan sama akan menerima upah yang berbeda, karena prestasinya berbeda, meskipun gaji pokoknya/dasarnya sama. Perbedaan tersebut merupakan tambahan upah (bonus) karena adanya kelebihan prestasi yang membedakan satu pegawai dengan yang lain.

b. Kompensasi pelengkap;

Kompensasi pelengkap merupakan salah satu bentuk pemberian kompensasi berupa penyediaan paket benefit dan program-program pelayanan karyawan, dengan maksud pokok untuk mempertahankan keberadaan karyawan sebagai anggota organisasi dalam jangka panjang. Kalau upah dan gaji merupakan kompensasi langsung karena berkaitan dengan prestasi kerja, maka kompansasi pelengkap merupakan kompensasi tidak langsung berkaitan dengan prestasi kerja. Kompensasi pelengkap meliputi :

1) Tunjangan antara lain berbentuk : Pensiun, Pesangon, Tunjangan Kesehatan dan Asuransi Kecelakaan Kerja.

2) Pelayanan yang meliputi : Majalah, Sarana Olah Raga, Perayaan Hari Raya,dan Program Sosial Lainnya

c. Keamanan serta kesehatan karyawan

Pembinaan kesehatan karyawan atau anggota organisasi merupakan suatu bentuk kompensasi nonfinansial yang sangat penting dalam organisasi. Keadaan aman dan sehat seorang karyawan / anggota organisasi tercermin dalam sikap individual dan aktivitas organisasi karyawan yang bersangkutan.

\section{Jenis-Jenis dan Indikator Kompensasi}

Menurut Sutrisno (2009:5), kompensasi dibedakan menjadi dua macam, yaitu:

a. Kompensasi Langsung (Financial)

Kompensasi yang langsung dirasakan oleh penerimanya, yakni berupa gaji, tunjangan, dan insentif merupakan hak karyawan dan kewajiban perusahaan untuk membayarnya.

1). Gaji adalah balas jasa yang dibayar secara periodik kepada karyawan tetap serta mempunyai jaminan yang pasti. 
2). Tunjangan adalah kompensasi yang diberikan perusahaan kepadapara karyawannya, karena karyawannya tersebut dianggap telah ikut berpartisipasi dengan baik dalam mencapai tujuan perusahaan.

3). Insentif adalah kompensasi yang diberikan perusahaan kepada karyawan tertentu, karena keberhasilan prestasinya di atas standar atau mencapai target.

4). Bonus adalah Pemberian bonus kepada karyawan dimaksudkan untuk meningkatkan produktivitas kerja dan semangat kerja karyawan.

b.. Kompensasi Tidak Langsung (Non Financial)

Kompensasi yang tidak dapat dirasakan secara langsung oleh karyawan, yakni benefit dan service adalah kompensasi tambahan yang diberikan berdasarkan kebijaksanaan perusahan terhadap semua karyawan dalam usaha meningkatkan kesejahteraan mereka seperti uang pensiun, dan olah raga.

\section{Pembayaran Berdasarkan Prestasi}

Menurut widodo (2015:164) dalam hal ini ada berbagai cara pembayaran berdasarkan prestasi yang perlu diketahui antara lain:

a. Pembayaran berdasarkan prestasi individu.

b. Pembayaran berdasarkan prestasi kelompok kerja.

c. Pembayaran berdasarkan prestasi dari unit perusahaan yang bersangkutan.

d. Pembayaran berdasarkan prestasi dari perusahaan secara keseluruhan.

\section{Tunjangan}

Menurut Herman (2008:167) Macam-macam tunjangan bagi karyawan dapat berupa

a. Tunjangan keselamatan

b. Tunjangan pada waktu tidak bekerja

c. Bonus hadiah

d. Program pelayanan karyawan

\section{Insentif}

Menurut Marwansyah (2016:278), beberapa macam insentif yang dapatdiberikan kepada karyawan antara lain.

a. Dorongan material uang atau barang 
b. Kesempatan untuk mendapatkan kehormatan, prestasi dan kekuasaan perseorangan

c. Syarat-syarat pekerjaan yang diinginkan bersih, lingkungan yang tenang atau ruang kotor yang tersendiri

d. Kebanggaan akan pekerjaannya, jasa untuk keluarga, dan patriotisme atau perasaan keagamaan

e. Kesenangan perseorangan dan kepuasan dalam hubungan-hubungan sosial dan organisasi

f. Persesuaian dengan kebiasaan praktik dan sikap biasa, serta dapat menerima aturan dan pola-pola tingkah laku perusahaan

g. Perasaan turut serta dalam kejadian atau peristiwa yang penting dalam perusahaan

8. Dimensi dan Indikator Kompensasi

Menurut Marihot Tua Efendi (2010:261), beberapa dimensi dan indikator kompensasi diantaranya adalah sebagai berikut :

a. Kompensasi Langsung

1) Gaji

2) Insentif

3) Fasilitas

b Kompensasi Tidak Langsung

1) Tunjangan

2) Dana Pensiun

3). Jaminan Kesehatan

9. Tujuan Kompensasi

Tujuan perusahaan memberikan kompensasi yaitu (Rachmawati, 2008: 144-145)

a. Mendapatkan karyawan yang berkualitas

b. Mempertahankan karyawan yang sudah ada

c. Adanya keadilan

d. Perubahan sikap dan perilaku

e. Efisiensi biaya

f. Administrasi legalitas (Dalam administrasi kompensasi juga terdapat batasan legalitas karena diatur oleh pemerintah dalam sebuah Undang-Undang. 
Tujuannya agar perusahaan tidak sewenang-wenang memperlakukan karyawan sebagai aset perusahaan)

\section{Tujuan Kompensasi}

Menurut Hasibuan (2017:121), tujuan pemberian kompensasi antara lain:

a. Ikatan kerja sama

b. Kepuasan kerja

c. Pengadaan efektif (Jika program kompensassi ditetapkan cukup besar, pengadaan karyawan yang qualified untuk perusahaan lebih mudah)

d. Motivasi (Jika balas jasa yang diberikan cukup besar, manajer akan lebih mudah memotivasi bahawannya)

e. Stablitas karyawan

f. Disiplin

g. Pengaruh serikat buruh (Dengan program kompensasi yang baik pengaruh Serikat Buruh dapat dihindarkan dan karyawan akan konsenterasi pada pekerjaannya)

h. Pengaruh buruh (Jika program kompensasi sesuai dengan undang-undang perburuhan yang berlaku (seperti batas upah minimum), maka intervensi pemerintah dapat dihindari)

\section{Asas Kompensasi}

Menurut Hasibuan (2017:122), asas kompensasi harus berdasarkan asas adil dan asas layak serta mempertahankan undang-undang perburuhan yang berlaku.

a. Asas adil

Besarnya kompensasi harus sesuai dengan prestasi kerja, jenis pekerjaan, tanggung jawab dan jabatan

b. Asas layak dan wajar

Suatu kompensasi harus disesuaikan dengan kelayakannya. Meskipun tolak ukur layak sangat relatif, perusahaan dapat mengacu pada batas kewajaran yang sesuai dengan ketentuan yang diterapkan oleh pemerintah dan aturan lain secara konsisten

\section{Persyaratan yang Mempengaruhi Kompensasi}

Menurut Jahrie dan Hariyoto (1999: 116-118) ada beberapa persyaratan yang 
harus dipenuhi dalam memberikan kompensasi kepada karyawan. Persyaratan menghendaki bahwa kompensasi itu haruslah:

a. Dapat memenuhi kebutuhan fisik minimum

b. Dapat menikat karyawan agar tidak keluar dari perusahaan

c. Dapat menimbulkan semangat dan kegairahan kerja

d. Bersifat adil dan layak

e. Selalu ditinjau kembali

f. Mencapai sasaran yang diinginkan

g. Mengangkat harkat kemanusiaan

h. Berpijak pada peraturan perundang-undangan yang berlaku

13. Faktor-Faktor yang Mempengaruhi besarnya kompensasi

Faktor-Faktor yang Mempengaruhi besarnya kompensasi, antara lain (Malayu, 2003: 127-129):

a. Penawaran dan permintaan tenaga kerja

b. Kemampuan dan kesediaan perusahaan

c. Serikat buruh atau organisasi karyawan

d. Produktivitas kerja karyawan

e. Pemerintah dengan Undang-Undang keppres

f. Biaya hidup (cost of living)

g. Posisi jabatan karyawan

h. Pendidikan dan pengalaman kerja

i. Kondisi perekonomian nasional

j. Jenis dan sifat pekerjaan

14. Dasar Pemberian Kompensasi

Penentuan tersebut dapat dibedakan atas beberapa dasar, yaitu (Jahrie dan Hariyoto, 1999: 119-120) :

a. Kompensasi berdasarkan satuan volume yang dihasilkan

b. Kompensasi berdasarkan satuan waktu

c. Kompensasi berdasarkan penilaian kerja 


\section{Sistem Kompensasi}

Menurut Sutrisno (2009:195)

Sistem pembayaran kompensasi yang umum diterapkan diantaranya adalah:

a. Sistem waktu

Dalam sistem waktu kompensaasi diterapkan berdasarkan standar waktu seperti jam, hari, minggu, atau bulan

b. Sistem hasil

Besarnya kompensasi ditetapkan atas kesatuan unit yang dihasilkan pekerja, seperti perpotong, permeter, liter dan kilogram.

c. Sistem borongan

Suatu cara pengupahan yang penetapan besarnya jasa didasarkan atas volume pekerjaan dan lama mengerjakannya

16. Aspek yang menentukan besarnya kompensasi

a. Tuntutan keahlian (skill) yang meliputi pengetahuan, pengalaman dan kemandirian

b. Tuntutan upaya (effort) meliputi tuntutan fisik dan tuntutan perhatian

c. Tuntutan tanggung jawab meliputi besarnya atau nilai peralatan, material, keuangan, keselamatan dan kepemimpinan yang menjadi tangggung jawabnya

d. Tuntutan lingkungan yang meliputi keadaan lingkungan kerja dan bahaya kecelakaan

17. Karakteristik Kompensasi yang Optimal

a. Arti penting

Sebuah imbalan tidak bakal dapat mempengaruhi apa yang dilakukan oleh orang-orang atau bagaimana perasaan mereka jika hal tersebut tidak penting bagi mereka.

b. Fleksibilitas

Prasyarat yang perlu untuk merancang system imbalan yang terkait dengan individu-individu.

c. Frekuensi,

Semakin sering suatu imbalan dapat diberikan, semakin besar potensi daya gunanya sebagai alat yang mempengaruhi kinerja karyawan. 
d. Visibilitas,

Imbalan-imbalan yang dapat dilihat jika dikehendaki supaya kalangan karyawan merasakan adanya hubungan antara kinerja dan imbalanimbalan.

e. Biaya,

Sistem kompensasi nyata sekali tidak dapat dirancang tanpa pertimbangan yang diberikan terhadap biaya imbalan-imbalan yang tercakup.

\section{Penentuan Kompensasi}

Besarnya kompensasi yang diberikan ditentukan oleh:

a. Harga / Nilai pekerjaan

Penilaian harga suatu jenis pekerjaan merupakan tindakan pertama yang dilakukan dalam menentukan besarnya kompensasi yang akan diberikan kepada karyawan. Penilaain harga pekerja dapat dilakukan dengan dua cara, sebagai berikut :

1). Melakukan analisis jabatan/pekerjaan

2). Melakukan survei harga pekerjaan sejenis pada organisasi lain.

b. Sistem kompensasi yang diterapkan, dan

Beberapa sistem kompensasi yang biasa digunakan adalah sistem prestasi, sistem kontrak/borongan.

a. Sistem Prestasi

Upah menurut prestasi kerja sering juga disebut dengan upah sistem hasil. Cara ini dapat mendorong karyawan yang kurang produktif menjadi lebih produktif. Contoh kompensasi sistem hasil : per potong, per meter, per kilo, per liter dan sebagainya.

b. Sistem Waktu

Besarnya kompensasi dihitung berdasarkan standar waktu seperti Jam, Hari, Minggu, Bulan. Besarnya Upah ditentukan oleh lamanya karyawan melaksanakan atau menyelesaikan suatu pekerjaan.

c. Sistem kontrak/ borongan

Penetapan besarnya upah dengan sistem kontrak / borongan didasarkan atas kuantitas, kualitas dan lamanya peyelesaian pekerjaan yang sesuai dengan kontrak perjanjian

c. Faktor-faktor yang mempengaruhi kompensasi. 
1) Sistem Waktu

Tabel 11.1 Kelemahan dan kelebihan sistem waktu

\begin{tabular}{|c|l|l|}
\hline No & \multicolumn{1}{|c|}{ Kelemahan Sistem Waktu } & \multicolumn{1}{c|}{ Kelebihan Sistem Waktu } \\
\hline 1. & $\begin{array}{l}\text { Mengakibatkan mengendornya } \\
\text { semangat karyawan yang } \\
\text { produktifitasnya tinggi (diatas rata-rata ) }\end{array}$ & $\begin{array}{l}\text { Dapat mencegah hal-hal yang } \\
\text { kurang diinginkan seperti pilih kasih, } \\
\text { diskriminasi maupun kompetisi yang } \\
\text { kurang sehat }\end{array}$ \\
\hline 2. & $\begin{array}{l}\text { Tidak membedakan usia, pengalaman, } \\
\text { dan kemampuan karyawan }\end{array}$ & $\begin{array}{l}\text { Menjamin kepastian penerimaan } \\
\text { upah secara periodik }\end{array}$ \\
\hline 3. & $\begin{array}{l}\text { Membutuhkan pengawasan yang ketat } \\
\text { agar karyawan sungguh- sungguh } \\
\text { bekerja }\end{array}$ & $\begin{array}{l}\text { Tidak memandang rendah karyawan } \\
\text { yang cukup lanjut usia }\end{array}$ \\
\hline 4. & $\begin{array}{l}\text { Kurang mengakui adanya prestasi kerja } \\
\text { karyawan }\end{array}$ & \\
\hline
\end{tabular}

2) Tahapan Menetapkan Kompensasi

Tahap 1:

Mengevaluasi tiap pekerjaan, dengan menggunakan informasi analisis pekerjaan, untuk menjamin keadilan internal yang didasarkan pada nilai relative setiap pekerjaan

Tahap 2 :

Melakukan survei upah dan gaji untuk menentukan keadilan eksternal yang didasarkan pada upah pembayaran dipasar kerja.

Tahap 3 :

Menilai harga tiap pekerjaan untuk menentukan pembayaran upah yang didasarkan pada keadilan internal dan eksternal.

19. Tahapan Pemberian Kompensasi

a. Menyelenggarakan survey gaji, yaitu survey mengenai jumlah gaji yang diberikan bagi pekerjaan yang sebanding di perusahaan lain (untuk menjamin keadilan eksternal),

b. Menentukan nilai tiap pekerjaan dalam perusahaan melalui evaluasi pekerjaan (untuk menjamin keadilan internal),

c. Mengelompokkan pekerjaan yang sama / sejenis ke dalam tingkat upah yang sama pula (untuk menjamin employee equity / keadilan karyawan),

d. Menetapkan harga tiap tingkatan gaji dengan menggunakan garis upah, 
e. Menyesuaikan tingkat upah dengan peraturan perundang-undangan yang berlaku (menjamin gaji layak dan wajar)

\section{Kompensasi Keamanan}

Samsudin (2005:203) menyatakan:

" Keamanan (safety) adalah keadaan karyawan yang bebas dari rasa takut dan bebas dari segala kemungkinan kecelakaan kerja ".

Handoko (dalam samsudin, 2005:203) mengemukakan sebagai berikut:

Program-program keamanan yang dapat dilakukan antara lain:

a. Menggunakan mesin-mesin yang dilengkapi alat-alat pengaman;

b. Menggunakan peralatan yang lebih baik;

c. Mengatur layout pabrik dan penerangan sebaik mungkin;

d. Lantai-lantai, tangga-tangga, bebas dari air, minyak, dan oli;

e. Melakukan pemeliharaan fasilitas pabrik secara baik;

f. Menggunakan berbagai pentunjuk dan peralatan keamanan, beserta larangan-larangan yang perlu;

g. Mendidik para karyawan dalam hal keamanan;

h. Membentuk komite manajemen serikat kerja untuk memecahkan masalah-masalah keamanan, dsb.

\section{B. Sub Materi 2: Kewajiban Perusahaan}

Secara umum, kewajiban organisasi/perusahaan dalam meningkatkan keamanan atau keselamatan kerja dapat disimpulkan sebagai berikut:

1. Memelihara tempat kerja yang aman dan sehat bagi karyawan;

2. Mematuhi semua standard an syarat kerja;

3. Mencatat semua peristiwa kecelakaan yang terjadi berkaitan dengan keselamatan kerja

\section{Keselamatan Kerja}

Keselamatan mencakup dua istilah, yaitu risiko keselamatan dan risiko kesehatan. Dalam bidang kepergawaian, kedua istilah tersebut dibedakan.

a. Keselamatan kerja menunjukkan kondisi aman atau selamat dari penderitaan,kerusakan atau kerugian di tempat kerja. Risiko keselamatan merupakan aspek-aspek darilingkungan kerja yang dapat menyebabkan 
kebakaran, ketakutan aliran listrik terpotong, lukamemar, patah tulang, kerugian alat tubuh, penglihatan, dan pendengaran. Semua itu seringdihubungkan dengan perlengkapan perusahaan atau lingkungan fisik dan mencakup tugas-tugaskerja yang membutuhkan pemeliharaan dan latihan.

b. Kesehatan kerja menunjukkan pada kondisi yang bebas dari gangguan fisik, mental, emosi atau rasa sakit yang disebabkan olehlingkungan kerja. Risiko kesehatan merupakan faktor-faktor dalam lingkungan yang dapatmembantu stress, emosi, dan gangguan fisik.

\section{Peraturan Kesehatan \& Keselamatan Kerja}

Di Indonesia keselamatan dan kesehatankerja diatur dalam Undang-Undang nomor 1 tahun 1970 yang berlaku sejak tanggal 12 januari1970 dalam pasal 3 ayat (1) mengemukakan sebagai beriku:

a. Mencegah dan mengurangi kecelakaan;

b. Mencegah, mengurangi, dan memadamkan kebakaran;

c. Mencegah dan mengurangi bahaya peledakan;

d. Memberi kesempatan atau jalan keselamatan diri pada waktu kebakaran atau kejadian-kejadian yang berbahaya;

e. Memberi pertolongan pada kecelakan;

f. Memberikan alat-alat perlindungan diri pada pekerja

g. Mencegah dan mengendalikan tumbulnya atau menyebar luaskan suhu, kelembaban,debu, kotoran, asap, uap, gas, hembusan angina, cuaca, sinar atau radiasi, suara dangetaran

h. Mencegah dan mengendalikan timbulnya penyakit akibat kerja baik fisik maupun psikis, peracunan, infeksi, dan penularan;

i. Memperoleh penerangan yang cukup sesuai;

j. Menyelenggarakan suhu dan lembab udara uang cukup;

k. Menyelenggarakan penyegaran udara yang cukup;

1. Memelihara kebersihan, kesehatan, dan ketertiban;

m. Memperoleh keserasian antara lembaga tenaga kerja, alat kerja, lingkungan, cara, dan proses kerjanya.

n. Mengamankan dan memperlancar pengangkutan orang, binatang, tanaman, atau barang; 
o. Mengamankan dan memelihara segala jenis bangungan;

p. Mengamankan dan memperlancar pekerjaan bongkar muat, perlakuan, dan penyimpanan barang;

q. Mencegah terkena aliran listrik yang berbahaya; dan

r. Menyesuaikan dan menyempurnakan pengaman pada pekerjaan yang bahayakecelakaannya menjadi bertambah tinggi

\section{Pedoman K3}

Pemerintah merumuskan pedoman sistem manajemen keselamatan dan kesehatan kerja yangdituangkan dalam Peraturan Pemerintah (PP) Nomor Per.05/MEN/1996 tentang sistemmanajemen keselamatan kerja.Inti peraturan tersebut adalah:

a. Tujuan dan sasaran sistem manajemen keselamatan dan kesehatan kerja (K3), yaitumenciptakan suatu sistem keselamatan dan kesehatan kerja di tempat kerja yangmelibatkan manajemen, tenaga kerja, kondisi, dan lingkungan kerja yang terintegrasiuntuk mencegah, mengurangi kecelakaan dan penyakit akibat kerja, dan menciptakantempat kerja yang efisien dan efektif (Pasal 1 PP No.05/MEN/1996).

b. Dalam rangka mencapai tujuan di atas, Pasal 4 PP Per.05/MEN/1996 menyatakan bahwa perusahaan wajib:

1) Menetapkan kebijakan keselamatan dan kesehatan kerja dan adanya komitmenterhadap penerapan sistem manajemen KK;

2) Merencanakan pemenuhan kebijakan, tujuan, dan sasaran penerapan keselamatandan kesehatan kerja;

3) Menerapkan kebijakan keselamatan dan kesehatan kerja secara efektif denganmengembangkan kemampuan dan mekanisme pendukung yang diperlukan untukmencapai kebijakan, tujuan, dan sasaran keselamatan dan kesehatan kerja;

4) Mengukur, memantau, dan mengevaluasi keselamatan dan kesehatan kerja sertamelakukan tindakan perbaikan dan pencegahan;

5) Meninjau secara teratur dan meningkatkan pelaksanaan sistem manajemen K3secara berkesinambungan dengan tujuan meningkatkan kinerja keselamatan dankesehatan kerja

c. PP No. Per.05/MEN/1996 selanjutnya undang-undang tersebut mengemukakan pedoman penerapan dan sistem manajemen keselamatan dan 
kesehatan kerja. Adapuninti pedoman tersebut adalah merumuskan berbagai aspek yang berkaitan dengankomitmen manajemen terhadap keselamatan dan kesehatan kerja, pelembagaan K3 di perusahaan, strategi, pelaksanaan, pengevaluasian, pengadministrasian, dan beberapaaspek yang terkait, dalam upaya perbaikan dan pencapaian tujuan program sebagai pedoman pelaksanaan, sebagaimana tertuang dalam Lampiran I Peraturan MenteriTenaga Kerja Nomor Per.05/MEN/1996 Tanggal 12 Desember 199

\section{Penerapan Keamanan Kerja}

Program-program keamanan dapat dilakukan dalam berbagai bentuk, misalnya membuat kondisi kerja aman, antara lain dengan :

a. Membeli atau mempergunakan mesin-mesin yang dilengkapi alat-alat pengaman,

b. Menggunakan peralatan-peralatan yang lebih baik,

c. Mengatur layout ruangan dan penerangan sebaik mungkin,

d. Lantai-lantai/tangga-tangga dan lerengan-lerengan harus dijaga agar bebas dari air, minyak, dan lain-lain,

e. Melakukan pemberian fasilitas kantor secara baik, dan

f. Menggunakan petunjuk-petunjuk dan peralatan-peralatan keamanan.

g. Mendidik padre karyawan dalam hal keamanan;

h. Membentuk komite manajemen serikat kerja untuk memecahkan masalah-masalahkeamanan, dan sebagainya

\section{Kompensasi Kesehatan}

Samsudin (2005:203) menyatakan sebagai berikut.

"Kesehatan pada dasarnya mencakup kesehatan jasmani maupun rohani. Seorang disebut sehat jasmani apabila seluruh unsur organisme badanialah seseorang itu berfungsi normaldan baik, yang berarti tanpa sakit, tanpa mengidap penyakit, dan tanpa kelemahan fisik.Sedangkan sehat rohaniah adalah bila seseorang sudah berhasil mengadaptasikan dirinya pada organisasi tempat ia bekerja, memiliki konsepsi yang akurat tentang kenyataan- kenyataan hidup, dapat mengatasi berbagai stress dan frustasi, dan sebagainya” 


\section{Penciptaan Lingkungan Kerja Sehat}

a. Menjaga kesehatan karyawan dari berbagai gangguan penglihatan, pendengaran,kelelahan, dan sebagainya (pengendalian suara asing, pengaturan penerangan tempat kerja, pengaturan suhu udara, pengaturan penggunaan warna, dan fasilitas istirahat).

b. Penyediaan fasilitas-fasilitas pengobatan dan pemeriksaan kesehatan bagi karyawandengan berbagai kemudahan sehingga terjangkau bagi setiap karyawan yang memerlukan (termasuk penyediaan dokter dengan staff nya)

\section{Pelayanan Kesehatan}

Perusahaan dapat memberikan pelayanan kesehatan dengan penyediaan dokterorganisasi dan klinik kesehatan perusahaan. Terkait dengan jaminan kesehatan kerja, jaminan inidasarnya tidak dapat dilepaskan kaitannya dengan perasaan aman dan puas (quality of work lofeatua QWL). Beberapa di antaranya adalah sebagai berikut.

a. Asuransi jiwa, yaitu sebagai jaminan kehidupan keluarga di masa depan bukanlahmenopoli atau hanya berlaku bagi para pekerja di lingkungan suatu organisasi/perusahaan

b. Kompensasi akibat pekerjaan. Kompensasi tidak langsung ini berbentuk suatu bantuan para pekerja yang sifat pekerjaannya dapat mengakibatkan terjadinya gangguan psikologis

c. Asuransi cacat tubuh. Asuransi ini termasuk asuransi kecelakaan, keadaan terburuk yangmenempatkan asuransi ini menjadi sangat penting adalah kecelakaan yang berakibat cacat jasmani (tubuh) sehingga pekerja tidak dapat lagi menjalankan fungsi utama dalam pekerjaannya

d. Biaya rumah sakit. Dalam penyelenggaraan jaminan kesehatan bagi pekerja, salah satu bentuknya adalah penyediaan biaya perawatan rumah sakit

e. Jaminan pengobatan lainnya. Jaminan ini memperluas kompensasi tidak langsung yangtidak sekedar mengenai pekerja yang menderita sakit berkepanjangan, tetapi juga berbagaiaspek kesehatan lainnya seperti perawatan dan pengobatan gigi, mata 


\section{MATERI XII}

\section{Kesepakatan Kerja}

\section{A. Sub Materi 1: Perjanjian}

Istilah perjanjian sebenarnya tidak dikenal dalam KUH Perdata, yang ada ialah perikatan atau verbintenis (Pasal 1233) dan persetujuan atau overeenkomst (Pasal 1313). Beberapa ahli hukum juga berpendapat dalam menggunakan istilah-istilah tersebut. Di Indonesia istilah verbintenis diterjemahkan dalam tiga arti, yaitu perikatan, perutangan dan perjanjian. Sedangkan istilah overeekomst diterjemahkan dalam dua arti, yaitu perjanjian dan persetujuan (Konsiden, 199:2). Jika menggunakan Pasal 1313 KUH Perdata, batasan pengertian perjanjian adalah suatu perbuatan di mana seseorang atau lebih meningkatkan diri pada orang lain untuk melaksanakan sesuatu hal. Manaj. Pengupahan dan Perburuhan

\section{Syarat Sah Perjanjian}

Untuk syahnya sebuah perjanjian kerja, maka pembuatannya harus memenuhi syarat material (pasal 52, 55, 58, dan 60 Undang-undang No. 13 Tahun 2003) dan syarat formil (pasal 54 dan 57 Undang-undang Nomor 13 tahun 2003) • Berdasarkan ketentuan Pasal 52 ayat (1) Undang-undang Nomor 13 tahun 2003 secara materill perjanjian kerja dibuat atas dasar:

a. Kesepakatan kedua belah pihak;

b. Kemampuan atau kecakapan melakukan perbuatan hukum;

c. Adanya pekerjaan yang diperjanjikan;

d. Pekerjaan yang diperjanjikan tidak bertentangan dengan ketertibahn umum, kesusilaan, dan peraturan perundang-undangan yang berlaku. Manaj. Pengupahan dan Perburuhan

\section{Asas Perjanjian}

Walau tidak ada satu pun peraturan yang mengikat tentang bentuk dan isi perjanjian, karena dijamin dengan adanya "asas kebebasan berkontrak" yakni suatu asas yang menyatakan bahwa setiap orang pada dasarnya boleh membuat kontrak (perjanjian) yang berisi dan macam apapun asal tidak bertentangan dengan undang-undang, kesusilaan, dan ketertiban umum. Asas kebebasan berkontrak dituangkan dalam 
Pasal 11338 ayat 1 KUH Perdata, dengan memperhatikan Pasal 1320, 1335 dan 1337 KUH Perdata di samping Pasal 52 Undang-undang Nomor 13 Tahun 2003 Ketenagakerjaan. Manaj. Pengupahan dan Perburuhan

\section{Pembagian Perjanjian (Pasal 1601 BW)}

a. Perjanjian untuk melakukan jasa-jasa tertentu, adalah suatu perjanjian dimana satu pihak menghendaki dari pihak lainnya agar dilakukan suatu perjanjian guna mencapai suatu tujuan, untuk itu salah satu pihak bersedia membayar upah,contoh : hubungan antara pasien dan dokter, pengacara dan klien, notaris dan klien dsb.

b. Perjanjian kerja, adalah perjanjian antara seorang buruh dan seorang majikan, perjanjian mana ditandai dengan ciri adanya suatu upah atau gaji tertentu yg diperjanjikan dan adanya suatu hubungan diperatas (dienstverhoeding), dimana pihak majikan berhak memberikan perintah-perintah yg harus ditaati oleh pihak lain

c. Perjanjian pemborongan kerja, adalah suatu perjanjian antara pihak yg satu dan pihak yg lain, dimana pihak yg satu (yg memborongkan pekerjaan) menghendaki sesuatu hasil pekerjaan yg disanggupi oleh pihak yg lain, atas pembayaran suatu uang tertentu sebagai harga pemborongan

\section{Perjanjian Kerja}

menurut pasal 1601 a KUH Perdata

Suatu persetujuan bahwa pihak kesatu yaitu buruh/pekerja mengikatkan diri untuk menyerahkan tenaganya kepada pihak lain, yaitu majikan/pengusaha dengan upah selama waktu tertentu

Shamad, :55

Perjanjian kerja adalah suatu perjanjian dimana seseorang mengikatkan diri untuk bekerja pada orang lain dengan menerima imbalan berupa upah sesuai dengan syarat-syarat yg dijanjikan atau disetujui bersama

\section{Unsur-Unsur Perjanjian Kerja}

Unsur hubungan kerja terdiri atas:

a. Para pihak sebagai subjek (pengusaha dan pekerja/buruh), 

b. Perjanjian kerja,
c. Adanya pekerjaan,
d. Upah dan
e. Perintah.

Dengan demikian, landasan hubungan kerja adanya perjanjian kerja, baik tertulis maupun tidak tertulis (lisan). - Sedangkan beberapa ahli berpendapat bahwa di dalam perjanjian yang menjadi dasar hubungan kerja adalah empat unsur penting yaitu: •

a. Adanya pekerjaan (pasal 1601 a KUH Perdata dan Pasal 341 KUH Dagang)

b. Adanya upah (pasal 1603 p KUH Perdata)

c. Adanya perintah orang lain (pasal 1603 b KUH Perdata)

d. Terbatas waktu tertentu, karena tidak ada hubungan kerja berlangsung terus menerus. Manaj. Pengupahan dan Perburuhan

\section{Prinsip-Prinsip Perjanjian Kerja}

Adanya keterikatan (antara pekerja/buruh dengan pengusaha/majikan) untuk bekerja dibawah perintah dengan menerima upah. Jadi bila seseorang telah mengikatkan diri dalam suatu perjanjian perjanjian kerja berarti ia secara pribadi secara otomatis harus bersedia bekerja dibawah perintah orang lain. Hal inilah yg disebut sebagai "hubungan diperatas" (dienstverhoeding)

\section{Bentuk dan Isi Perjanjian Kerja}

Aturan tentang kebebasan bentuk perjanjian itu merupakan aturan umum. Pasal 51 ayat (2) Undang-Undang Nomor 13 Tahun 2003 menentukan bahwa perjanjian kerja yang dipersyaratkan secara tertulis dilaksanakan sesuai dengan peraturan perundang-undangan yang berlaku. Pasal ini memberikan kemungkinan bahwa untuk perjanjian kerja tertentu dapat disyaratkan bentuk tertulis. Perjanjian kerja yang dipersyaratkan dalam bentuk tertulis di antaranya adalah:

a. Perjanjian kerja waktu tertentu (Pasal 57 ayat 1 Undang-Undang Nomor 13 Tahun 2003);

b. Antarkerja antardaerah;

c. Antarkerja antarnegara;

d. Perjanjian kerja laut 
8. Pihak-Pihak Terkait Dengan Perjanjian Kerja

a. Buruh/Pekerja

b. Pengusaha

Di dalam Pasal 1 Angka 5 Undang-Undang Nomor 13 Tahun 2003 menjelaskan pengertian pengusaha, yakni:

1). Orang perseorangan, persekutuan, atau badan hukum yang menjalankan suatu perusahaan milik sendiri;

2). Orang perseorangan, persekutuan, atau badan hukum yang secara berdiri sendiri menjalankan perusahaan bukan miliknya;

3). Orang perseorangan, persekutuan, atau badan hukum yang berada di Indonesia mewakili perusahaan sebagaimana dimaksud yang berkedudukan di luar wilayah Indonesia.

c. Organisasi Pekerja/Buruh

Kehadiran organisasi pekerja dimaksudkan untuk memperjuangkan hak dan kepentingan pekerja

d. Organisasi Pengusaha

1). Kamar dagang dan Industri

2). Asosiasi pengusaha Indonesia

e. Pemerintah/Penguasa

\section{Syarat Materiil Perjanjian Kerja}

Syarat materiil : syarat yg terdapat dlm pasal 52 ayat (1) UU ketenagakerjaan :

a. kesepakatan kedua belah pihak

b. kemampuan / kecakapan melakukan perbuatan hukum

c. Adanya pekerjaan yg diperjanjikan

d. Tidak bertentangan dgn. Ketertiban umum, kesusilaan dan per UU an yg berlaku

\section{Syarat Formil Perjanjian Kerja}

Syarat pembuatan secara formil harus memuat (Pasal 54 ayat (1) Undang-Undang Nomor 13 Tahun tentang Ketenagakerjaan):

a. Nama, alamat perusahaan dan jenis usaha;

b. Nama, jenis kelamin, umur dan alamat pekerja/buruh;

c. Jabatan atau jenis pekerjaan;

d. Tempat pekerjaan; 
e. Besarnya upah dan cara pembayarannya;

f. Syarat-syarat kerja yang memuat hak dan kewajiban pengusaha dan pekerja/buruh;

g. Jangka waktu mulai berlakunya perjanjian kerja;

h. Tempat dan lokasi perjanjian kerja dibuat; dan

i. Tanda tangan para pihak dalam perjanjian kerja

\section{Kewajiban Para Pihak Dalam Perjanjian Kerja}

a. Hubungan kerja terjadi setelah adanya perjanjian kerja, dan perjanjian kerja merupakan peristiwa hukum, sehingga konsekuensi suatu hubungan kerja menimbulkan akibat hukum berupa hak dan kewajiban bagi para pihak, yaitu pengusahan dan pihak pekerja/buruh.

b. Hak adalah suatu peranan yang boleh atau tidak boleh dilakukan oleh subjek hukum. Karenanya, jika hak dilanggar, tidak berakibat sanksi apa pun bagi pelakunya.

c. Sedangkan kewajiban adalah suatu peranan yang harus atau tidak harus dilakukan oleh subjek hukum. Karenanya, jika kewajiban dilanggar, berakibat sanksi bagi setiap pelakunya. Dalam kontek hubungan kerja, kewajiban para pihak berlangsung secara timbal baliknya "kewajiban pengusaha hak pekerja/buruh:, dan sebaliknya "kewajiban pekerja/buruh hak pengusaha." untuk itu jika terjadi pelanggaran kewajiban yang telah diatur peraturan undang-undangan atau perjanjian kerja, masing-masing pihak dapat menuntut pihak lainnya. Manaj. Pengupahan dan Perburuhan

\section{Kewajiban Para Pihak Dalam Perjanjian Kerja}

Kewajiban para pihak dalam hubungan kerja menurut KUH Perdata dan Undang-undang Nomor 13 Tahun 2003 Kewajiban Para Pihak Berdasarkan KUH Perdata

a. Kewajiban Pengusaha

1). Membayar upah kepada buruh (Pasal 1602)

2). Mengatur pekerjaan dan tempat kerja (Pasal 1602u, v, w, dan y)

3). Memberikancuti/libur (Pasal 1602x)

4). Mengurus perawatan/pengobatan buruh (Pasal $16022 \mathrm{x}$ )

5). Memberikan surat keterangan (1602 z) 
6) Kewajiban lainnya yang dimuat dalam perjanjian kerja, peraturan perusahaan, perjanjian kerja bersama, dengan syarat tidak melanggar 3 hal seperti diatur Pasal 1337 KUH Perdata.

b. Kewajiban Pekerja/buruh

1). Melaksanakan tugas/pekerjaan sesuai yang diperjanjikan dengan sebaik-baiknya (Pasal 1603)

2). Melaksanakan pekerjaan sendiri tidak dapat digantikan oleh orang lain tanpa izin dari pengusaha (Pasal 1603a)

3). Menaati peraturan dalam melaksanakan pekerjaan (Pasal 003b)

4). Menaati peraturan tata tertib dan tata cara yang berlaku di rumah/tempat majikan bila pekerja tinggal disana (Pasal 1603c)

5). Melaksanakan tugas dan kewajiban secara layak (Pasal 1603d)

6). Membayar ganti rugi atau denda (Pasal 1603w)

c. Kewajiban lainnya yang dimuat dalam perjanjian kerja, peraturan perusahaan, perjanjian kerja bersama, dengan syarat tidak melanggar 3 hal seperti diatur Pasal 1337 KUH Perdata Manaj. Pengupahan dan Perburuhan

13. Hal yang harus diperhatikan sebelum menandatangani perjanjian kerja

a. Teliti kata demi kata. Perhatikan apakah perjanjian kerja itu di buat dengan menggunakan dua bahasa seperti Bahasa Indonesia dan Bahasa Inggris. Usahakan jangan sampai terdapat terjemahan yang tidak tepat, sebab maknanya akan sangat berbeda. Perjanjian kerja itu harus di buat dengan bahasa baku.

b. Jika bingung dengan isi perjanjian itu usahakan agar bertanya kepada pihak perusahaan.

c. Periksa kembali apakah perjanjian kerja itu sudah di bubuhi materai. Pembubuhan materai ini berarti akan menambah kekuatan hukum perjanjian kerja, jika dikemudian hari terjadi kekeliruan.

d. Setelah perjanjian ditandatangani, jangan lupa calon karyawan meminta salinannya untuk disimpan. Ini penting untuk mencegah jangan sampai terjadi kekeliruan yang berkenaan dengan perjanjian kerja di kemudian hari

\section{Jenis Perjanjian Kerja}

Departemen Tenaga Kerja dan Transmigrasi Republik Inodonesia (2003:14-25) membagi perjanjian kerja menjadi dua jenis, yaitu: 
a. Berdasarkan waktu berlakunya:

1). Kesepakatan Kerja Waktu Tidak Tertentu (KKWTT); dan

2). Kesepakatan Kerja Waktu Tertentu(KKWT)

b. Perjanjian kerja lainnya:

1). Perjanjian pemborong pekerjaan

2). Perjanjian kerja bagi hasil

3). Perjanjian kerja laut

4). Perjanjian untuk melakukan jasa-jasa.

15. Secara yuridis maupun empiris, perjanjian kerja dapat dibagi dalam empat kelompok, yaitu

a. Berdasarkan bentuk perjanjian,

b. Jangka waktu perjanjian,

c. Status perjanjian, dan

d. Pelaksanaan pekerjaan. Manaj. Pengupahan dan Perburuhan

Secara yuridis maupun empiris, perjanjian kerja dapat dibagi dalam empat kelompok, yaitu berdasarkan bentuk perjanjian, jangka waktu perjanjian, status perjanjian, dan pelaksanaan pekerjaan.

a. Berdasarkan bentuk perjanjian kerja. Berdasarkan bentuknya, perjanjian kerja dibagi menjadi dua macam (pasal 51 ayat (1) undang-undang Nomor 13 tahun 2003) yaitu:

1). Perjanjian kerja secara tertulis

2). Perjanjian kerja secara lisan (tidak tertulis)

b. Berdasarkan jangka waktu perjanjian kerja. Berdasarkan jangka waktunya, perjanjian kerja dibagi menjadi dua macam yaitu:

1). Perjanjian kerja waktu tertentu (PKWT)

2). Perjanjian kerja waktu tidak tertentu (PKWTT)

c. Berdasarkan status perjanjian kerja. Berdasarkan status perjanjiannya, perjanjian kerja dibagi menjadi 2 macam yaitu:

1). Perjanjian kerja tidak tetap

2). Perjanjian kerja tetap Manaj. Pengupahan dan Perburuhan

16. Pembagian Perjanjian Kerja Berdasar Jangka Waktu

a. Perjanjian Kerja Waktu Tertentu (PKWT) 
PKWT adalah perjanjian kerja antara $\mathrm{P} / \mathrm{B}$ dengan pengusaha yg hanya dibuat untuk pekerjaan tertentu yg menurut jenis dan sifat atau kegiatan pekerjaannya akan selesai dalam waktu tertentu. Perjanjian ini diatur dalam pasal 56 s/d. pasal 60 UU Ketenagakerjaan

b. Hal-hal yg perlu diperhatikan dalam PKWT :

1). PKWT tidak dapat mensyaratkan adanya masa percobaan kerja, bila ada maka batal demi hukum

2). PKWT hanya dapat dibuat untuk pekerjaan tertentu yg menurut jenis dan sifat pekerjaannya akan selesai dalam waktu tertentu

3). PKWT dibuat dalam rangkap 3 (tiga), yaitu untuk pekerja, pengusaha dan dinas yg membidangi ketenagakerjaan setempat

4). Seluruh biaya yg timbul dlm pembuatan PKWT menjadi tanggungan pengusaha

c. Pekerjaan yang bersifat musiman;

Keputusan Menteri Tenaga Kerja dan Transmigrasi Nomor ; KEP. 100/MEN/VI/2004 tentang Ketentuan Pelaksanaan Perjanjian Kerja Waktu Tertentu yang merupakan peraturan pelaksana dari Pasal 59 ayat (8) Undang undang Nomor 13 Tahun 2003 tentang Ketenagakerjaan, menetapkan kategori pekerjaan untuk Perjanjian Kerja Waktu Tertentu (PKWT) sebagai berikut :

1). Pekerjaan yang sekali selesai atau sementara sifatnya yang penyelesaiannya paling lama 3 (tiga) tahun;

2). Pekerjaan yang bersifat musiman;

3). Pekerjaan yang berhubungan dengan produk baru, kegiatan baru atau produk tambahan yang masih dalam percobaan atau penjajagan

d. Perjanjian Kerja Waktu Tidak Tertentu

Perjanjian ini terdapat dalam pasal 1603 q ayat (1) KUHPerdata, dimana dinyatakan bahwa lamanya hubungan kerja tidak ditentukan,baik dalam perjanjian, peraturan majikan maupun dalam peraturan perundang-undangan atau pula menurut kebiasaan maka hubungan kerja itu diadakan untuk waktu tidak tertentu

Pasal 57 ayat (2) UU Ketenagakerjaan, disamping alasan tersebut diatas, PKWTT secara hukum otomatis terjadi sebagai akibat pelanggaran pengusaha thdp. Pasal 57 ayat (1). 
Pengertian PKWTT : suatu perjanjian kerja antara P/B dan pengusaha dimana jangka waktunya tidak ditentukan, baik dalam perjanjian, UU maupun kebiasaan, atau terjadi secara hukum karena pelanggaran pengusaha terhadap ketentuan perundang-undangan yg berlaku

\section{Macam Perjanjian Kerja}

a. Berdasarkan pelaksanaan pekerjaan

Secara yuridis pengelompokan perjanjian kerja berdasarkan pelaksanaan pekerjaan mengacu pada ketentuan Pasal 64 sampai 66 Undang-undang Nomor 13 Tahun 2003. Menyebutkan bahwa: "Perusahaan dapat menyerahkan sebagian pelaksanaan pekerjaan kepada perusahaan lainya melalui perjanjian pemborongan pekerjaan atau penyediaan jasa pekerja/buruh yang dibuat secara tertulis." Pengelompokan perjanjian kerja berdasarkan pelaksanaan pekerjaan dibagi menjadi 2 (dua) macam, yaitu:

1).Dilakukan sendiri oleh perusahaan

2) .Diserahkankepadaperusahaan lain (outsourcing)

b. Perjanjianpemboronganpekerjaan, dan

c. Perjanjian jasa pekerja/buruh. Manaj. Pengupahan dan Perburuhan

18. Hubungan Perjanjian Kerja dan Perjanjian Perburuhan

Hubungan kerja terjadi karena adanya perjanjian kerja antara pengusaha dan pekerja/buruh, yang mempunyai unsur pekerjaa, upah dan perintah. "Suatu hubungan antara seorang buruh dan seorang majikan, di mana hubungan kerja itu terjadi setelah adanya perjanjian, di antara dua belah pihak. Mereka terkait dalam suatu perjanjian, di suatu pihak pekerja/buruh bersedia bekerja dengan menerima upah dan pengusaha memperkerjakan pekerja/buruh dengan memberi upah". (Soepomo, 1987:

\section{Hak-Hak Pekerja Perempuan}

a. Pengusaha dilarang memperkerjakan antara pukul 23.00 sampai dengan 07.00 terhadap pekerja/buruh perempuan yang berumur kurang dari delapan belas tahun (pasal 76 ayat (1)).

b. Pengusaha dilarang memperkerjakan pekerja/buruh perempuan hamil yang menurut keterangan dokter berbahaya, baik bagi kesehatan dan keselamatan 
kandungannya maupun dirinya apabila bekerja antara pukul 23.00 sampai jam 07.00 (pasal 76 ayat (2))

c. Pengusaha yang mempekerjakan pekerja/buruh perempuan antara pukul 23.00 sampai dengan jam 07.00 (pasal 76 ayat (3) Wajib : Memberikan makanan dan minuman bergizi

d. Menjaga kesusilaan dankeamanan selama di tempat kerja

e. Pengusaha wajib menyediakan angkutan anterjemput bagi pekerja/buruh perempuan yang berangkat dan pulang bekerja antara pukul 23.00 sampai dengan 05.00 (Pasal 76 ayat (4)).

f. Pekerja/buruh perempuan yang dalam masa haid measakan sakit dan memberitahukan kepada pengusaha, tidak wajib bkerja pada hari pertama dan kedua pada waktu haid (Pasal 81 ayat (1) Undang-undang Nomor 13 tahun 2003) Manaj. Pengupahan dan Perburuhan

g. Pekerja/buruh perempuan berhak memperoleh istirahat selama 1,5 bulan sebelum saatnya melahirkan anak dan 1,5 bulan sesudah melahirkan menurut perhitungan dokter kandungan atau bidan (Pasal 82 ayat (1) Undang-undang Nomor 13 Tahun 2003)

h. Pekerja/buruh perempuan yang mengalami keguguran kandungan berhak memperoleh istirahat 1,5 bulan atau sesuai perhitungan dokter kandungan atau bidan (Pasal 82 ayat (2) Undang-undang Nomor 13 Tahun 2003)

i. Pekerja/buruh perempuan yang anaknya masih menyusu harus diberi kesempatan sepatutnya untuk menyusui anaknya jika hal harus dilakukan selama waktu kerja (Pasal 83 Undang-undang Nomor 13 Tahun 2003).

j. Sebagai tindak lanjut Pasal 27 ayat (3) dan (4) Undang-undang Nomor 13 Tahun 2003) tentang Ketenagakerjaan telah diterbitkan Keputusan Menteri Tenaga Kerja dan Transmigrasi Nomor Kep-224/Men/2003 tentang Kewajiban Pengusaha yang memperkerjakan pekerja/buruh Perempuan antara Pukul 23.00 sampai dengan Pukul 07.00. Manaj. Pengupahan dan Perburuhan 


\section{MATERI XIII}

\section{Mutu Manajemen SDM}

\section{A. Sub Materi 1: Mutu SDM}

Pada perusahaan yang berpola modern, pemahaman atas mutu manajemen menjadi point sangat penting, sehingga memunculka fenomena bajak - membajak pada profesional atau tenaga ahli yang dimiliki oleh perusahaan lain

Penerapan MMSDM yang berorientasi pada pengetahuan menjadi sangat penting, di mana jajaran SDM dan sistemnya memiliki akses dengan sumber-sumber pengetahuan yang mutakhir.

\section{Perspektif Mutu SDM}

a. Bagaimana penempatan posisi karyawan apakah berdasarkan spesialisasi atau perputaran pekerjaan secara periodikal

b. Sejauh mana perencanaan perusahaan dalam memberikan keahlian khusus pada sumber daya manusia yang dimilikinya ? baik melalui pendidikan yang terstruktur maupun dengan training - training tertentu sesuai dengan kebutuhan

c. Bagaimanakah analisis problem solving yang dilakukan oleh perusahaan dalam menangani masalah sumber daya manusianya

d. Apa saja aspek - aspek yang perlu diperhatikan dalam pengembangan mutu SDM ( HARDSKILLS vs SOFTSKILLS )

e. Bagaimanakah produktivitas kerja karyawan perusahaan selama ini? Bagaimana pula derajad motivasi, etika, dan disiplin kerja para karyawan? ATTITUDE

f. Bagaimana perhatian atas keselamatan kerja karyawan (termasuk pelayanan kesehatan), Contoh IPPKI

g. Apakah perusahaan sudah menerapkan perubahan manajemen yang handal, dalam menyiasati perubahan bisnis yg cepat

h. Apakah perusahaan sudah membangun departemen atau divisi pembelajaran, atau yang lebih dikenal dengan HRD (Human Resourches Development ) 


\section{Perspektif Mutu SDM}

Perspektif - perspektif tersebut seharusnya tercermin pada visi, misi, tujuan, serta strategi pengembangan mutu SDM perusahaan secara terintegrasi dan sekaligus merupakan turunan dari visi, misi, tujuan, serta strategi perusahaan secara keseluruhan dalam rangka mereposisikan peran karyawan sebagai unsur yang semakin penting dalam suatu organisasi

3. Batasan dan ciri-ciri mutu SDM

Quality Management System ( QMS ) yang diartikan sebagai manajemen yang mampu memberikan jaminan mutu kerja yang dihasilkan oleh unit - unit di dalam suatu organisasi ekonomi / perusahaan sebagai suatu sistem yang berkesinambungan dengan eksistensi yang berstandart Internasional. QMS memuat garis besar kebijakan dan prosedur yang harus dilakukan untuk memperoleh peningkatan performa bisnis. Tujuan pelaksanaan QMS adalah untuk mengelola dengan berbagai pendekatan sistematis dan secara berkesinambungan meningkatkan efektifitasnya sesuai dengan standart internasional yang mengutamakan kebutuhan - kebutuhan stakeholders

\section{Ciri-Ciri Mutu SDM}

a. Input mencakup unsur-unsur berikut.

1). Tingkat pendidikan dan pengetahuan (kecerdasan intelektual, emosional, spiritual, dan sosial) serta etika kerja.

2). Sikap atas pekerjaan dan produktivitas sebagai sistem nilai etos kerja, persepsi motivasi, dan sikap akan tantangan.

3). Tingkat ketrampilan manajerial dan operasional, kemampuan berkomunikasi, dan termasuk kepemimpinan.

4). Daya inisiatif, kreativitas, dan inovatif.

5). Kepemimpinan manajerial, teknis, mutu, dan kelompok.

6). Tingkat pengalaman kerja.

7). Tingkat kedisiplinan.

8). Tingkat kejujuran.

9). Tingkat kesehatan fisik dan mental kejiwaan.

b. Proses mencakup unsur-unsur berikut.

1). Kerja sama secara harmonis sesama rekan kerja bawahan dan atasan . 
2). Bekerja dalam sistem yang total.

3). Perubahan (peningkatan dan pengurangan) motivasi kerja.

4). Kejadian konflik horizontal dan vertikal.

5) Frekuensi daya prakarsa, kreativitas, dan inovatif.

6) Frekuensi dan ketepatan waktu kehadiran kerja.

7). Tingkat keselamatan dan keamanan kerja individual.

8). Tingkat kesehatan kerja.

9). Tingkat kerusakan mutu produksi.

10). Tingkat efisiensi kerja.

11). Tingkat komitmen kerja.

c. Output mencakup unsur-unsur berikut.

1). Pencapaian standar produktivitas kerja.

2). Pencapaian standar kinerja organisasi (produksi, biaya, dan keuntungan).

3). Pencapaian omset penjualan/ produksi (barang \& jasa ). Kesejahteraan karyawan.

5. Strategi dalam pengembangan mutu SDM

Pengembangan mutu SDM secara langsung berhubungan dengan kondisi atau keberadaan SDM itu sendiri yang dipengaruhi oleh faktor - faktor intrinsik maupun ekstrinsik

a. Faktor intrinsik meliputi tingkat pendidikan, tingkat pengalaman kerja, tingkat ketrampilan, dan motivasi untuk berkembang dari SDM

b. Sedangkan faktor - faktor yang bersifat ekstrinsik meliputi lingkungan keluarga, lingkungan ekonomi, lingkungan sosial budaya sampai dengan lingkunga belajar, termasuk di dalamnya perkembangan tehnologi.

\section{Unsur - Unsur SDM}

Bisa ditinjau ke dalam tiga sisi yaitu :

a. Sisi manusia dan kemanusiaan, dapat dilihat secara fisik (tangible) dan tidak dapat dilihat secara fisik (intangible)

b. Dari sisi aset perusahaan, SDM karyawan dapat dikembangkan sebagai proses investasi efekif. 
c. Sementara dari sisi manajemen antara lain berupa manajemen waktu, manajemen konflik, manajemen stress, manajemen kepemimpinan, manajemen pelatihan, dan pengembangan SDM.

Faktor lain yang sangat mempengaruhi kinerja dari karyawan atau SDM antara lain

a. Mutu SDM sangat didukung oleh kualitas komunikasi, keberhasilan manajemen kepemimpinan, adanya program-program peningkatan motivasi

b. Mutu SDM itu juga sangat bergantung pada perubahan manajemen yang dilakukan oleh perusahaan 


\section{DAFTAR PUSTAKA}

1. Jono M Munandar, dkk. 2014. Pengantar Manajemen "Panduan Komprehensif Pengelolaan Organisasi”. Bogor : IPB Press

2. Gary Yuld. 2009. Kepemimpinan Dalam Organisasi. Jakarta. Indeks

3. Stephen P Robins. 2006. Perilaku Organisasi. Jakarta. Indeks

4. Donal Lantu, dkk. 2007. Seven Leadership. Jakarta. Gradian Books

5. Joko Santoso M. 2008 More About Beyound Leadership. Jakarta. Elek media

6. James J Jones \& Donald. 2008. Human Resource Management In Education. Depok. Q Media

7. Didit,Darmawan. 2013. Prinsip-Prinsip Perilaku Organisasi. PT. Temprina Media Grafika. Surabaya.

8. Djuremi. 2016. Pengaruh Lingkungan Kerja , Budaya Organisai, Kepemimpinan Terhadap Kinerja Pegawai pada Dinas Pasar Kota Semarang. Skripsi. Semarang.

9. Donni Junni Priansa. 2014. Perencanaan dan Pengembangan Sumber Daya Manusia. Alfabeta. Bandung

10. Moorhed, Gregory dan Ricky, W. Griffin. 2013. Perilaku Organisasi. Salemba Empat. Jakarta.

11. Nanda, Irfan dkk. 2013. Pengaruh Komitmen Organisasional Terhadap Prestasi Kerja Karyawan AJB Bumi Putera. Universitas Brawijaya.

12. Nitisemito, Alex. 2000. Manajemen Personalia. Graha Indonesia. Jakarta. 